\title{
Responsiveness Summary for the Remedial Investigation/Feasibility Study for Management of the Bulk Wastes at the Weldon Spring Quarry, Weldon Spring, Missouri
}

August 1990

prepared by

J.M. Peterson and M.M. MacDonell

Environmental Assessment and Information Sciences Divislon, Argonne National Laboratory

prepared for

U.S. Department of Energy, Oak Ridge Operations Office, Weldon Spring Site Remedial Action Project under Contract W-31-109-Eng-38 


\section{CONTEN'TS}

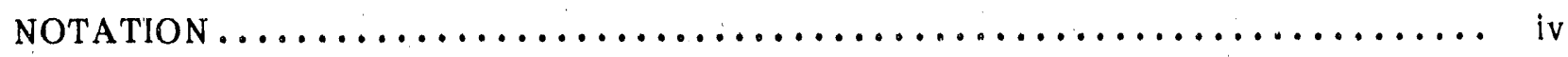

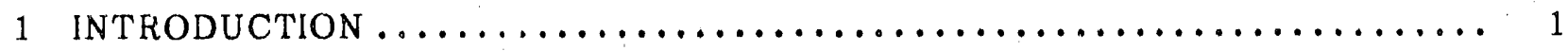

2 GENERAL ISSUES: COMMENTS AND RESPONSES $\ldots \ldots \ldots \ldots \ldots \ldots \ldots \ldots, 3$

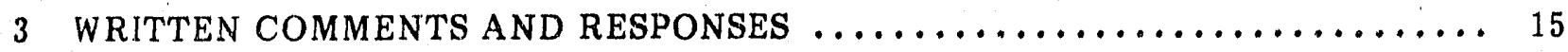

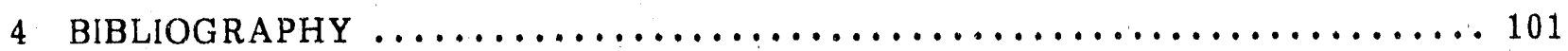




\section{NOTATION}

The following is a list of the acronyms, initialisms, and abbreviations (including units of measure) used in this document.

\section{ACRONYMS, INITIALISMS, AND ABBREVIATIONS}

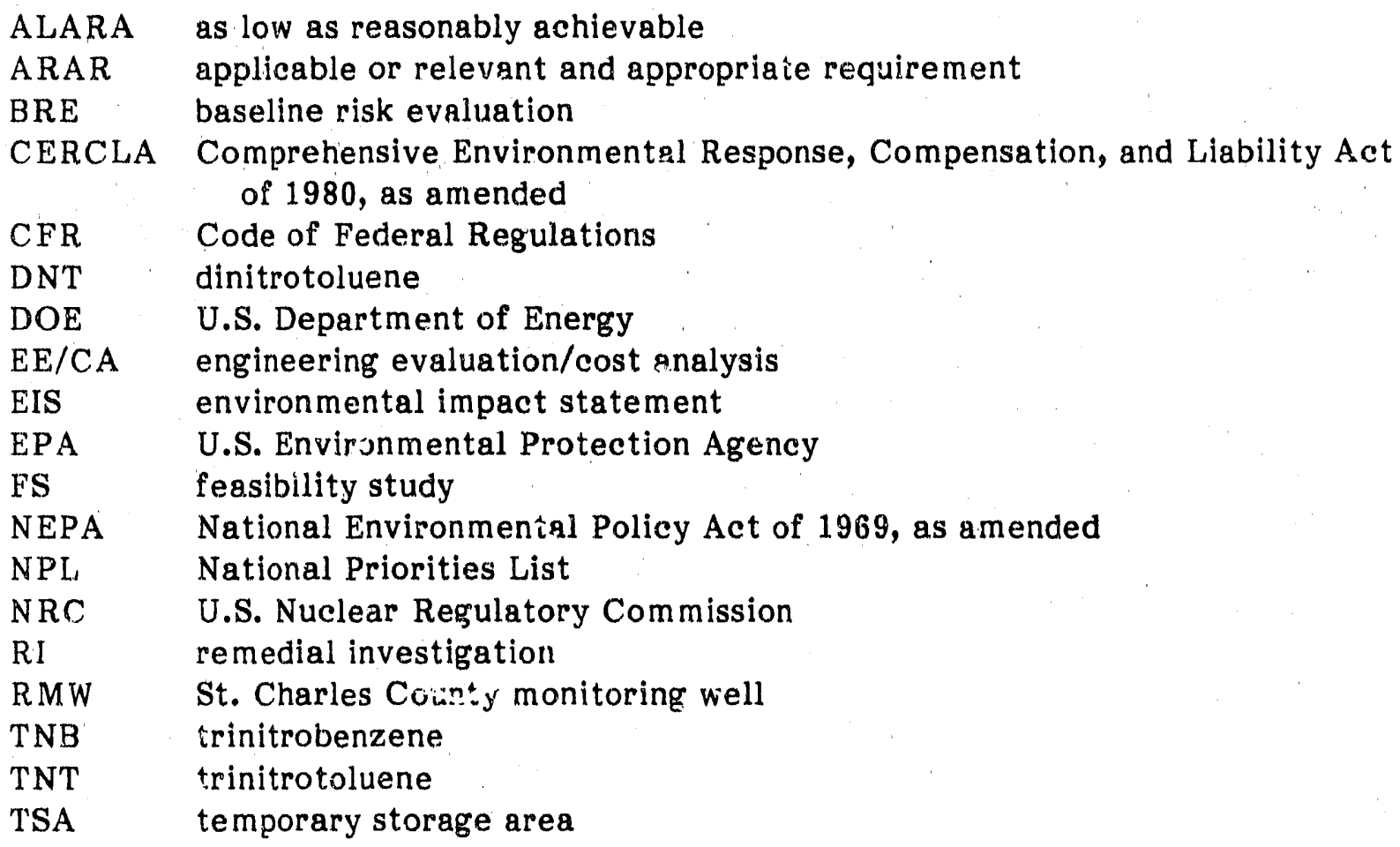

\section{UNITS OF MEASURE}

$\begin{array}{llll}\mathrm{cm} & \text { centimeter(s) } & \mathrm{mi} & \text { mile(s) } \\ \mathrm{h} & \text { hour(s) } & \mathrm{mrem} & \text { millirem(s) } \\ \mathrm{ha} & \text { hectare(s) } & \mathrm{pCi} & \text { picocurie(s) } \\ \mathrm{in} . & \text { inch(es) } & \mathrm{rem} & \text { roentgen equivalent man } \\ \mathrm{km} & \text { kilometer(s) } & \mathrm{s} & \text { second(s) } \\ \mathrm{L} & \text { liter(s) } & \mathrm{yd}^{3} & \text { cubic yard(s) } \\ \mathrm{m}^{2} & \text { square met } \mathrm{sr}(\mathrm{s}) & \mathrm{yr} & \text { year(s) } \\ \mathrm{m}^{3} & \text { cubic meter(s) } & & \end{array}$




\section{INTRODUCTION}

The U.S. Department of Energy (DOE) is responsible for conducting remedial actions at the Weldon Spring site in St. Charles County, Missouri, under its Surplus Facilities Management Program. The site consists of a quarry and a chemical plant area located about $6.4 \mathrm{~km}$ ( $4 \mathrm{mi})$ northeast of the quarry. The quarry is surrounded by the Weldon Spring Wildlife Area and is near an alluvial well field that constitutes a major source of potable water for St. Charles County; the nearest supply well is located about $0.8 \mathrm{~km}(0.5 \mathrm{mi})$ southerst of the quarry. From 1942 to 1969 , the quarry was used for the disposal of various radioactively and chemically contaminated materials. Bulk wastes in the quarry consist of contaminated soils and sediments, rubble, metal debris, and equipment. As part of overall site remediation, DOE is proposing to conduct an interim remedial action at the quarry to manage the radioactively and chemically contaminated bulk wastes contained therein.

Potential remedial action alternatives for managing the quarry bulk wastes have been evaluated consistent with U.S. Environmental Protection Agency (EPA) guidance for conducting remedial actions under the Comprehensive Environmental Response, Compensation, and Liability Act (CERCLA), as amended. The three primary documents that support the proposed management of the quarry bulk wastes are the remedial investigation (RI), the baseline risk evaluation (BRE), and the feasibility study (FS). The $\mathrm{RI}$ presents information on the environmental setting of the quarry and the physical, chemical, and radioactive characteristies of the bulk wastes. The BRE assesses the risks associated with current conditions at the quarry in the short term (i.e., the next several years). The FS develops, screens, and evaluates alternatives for managing the quarry bulk wastes. The contents of these documents were developed in consultation with EPA Region VII and the state of Missouri and reflect the fooused scope defined for this interim remedial action.

Based on the analyses in these documents, the preferred alternative for managing the quarry bulk wastes is to remove them from the quarry and transport them to a temporary storage facility at the chemical plant area. This interim action would (1) eliminate the primary source of radioactively and chemically contaminated materials from the quarry, (2) facilitate subsequent characterization of the quarry and its vicinity, and (3) support disposal decisions for the bulk wastes and other contaminated materials from the Weldon Spring site. A comprehensive assessment of the need for additional remedial action at the quarry will be performed following bulk waste removal and detailed characterization activities.

The RI/FS documents were issued to the general public on March 5, 1990. A public comment period was held from March 5, 1990, through April 9, 1990, consistent with the public participation process identified in CERCLA. Comments on the proposed action were received both in writing and at a public meeting held on March 29, 1990, at the Ramada Inn in Wentzville, Missouri. Representatives from DOE, EPA Region VII, and the state of Missouri participated in the meeting. Transcripts of the meeting are included as part of the administrative record associated with this interim action. Most of the questions raised by the public at this meeting were addressed orally. In addition to 
the public meeting, DOE held numerous briefings and meetings with public officials, school administrators, special interest groups, and members of the general public. These meetings, which were generally informal, allowed for an effective exchange of information and receipt of public input.

This document has been prepared to summarize and provide responses to the major issues identified in oral and written comments made on the proposed action. General issues are discussed in Chapter 2, and specific issues are discussed in Chapter 3. Chapter 3 includes copies of the letters recelved on the proposed action and responses to individual issues (comments) identified in these letters. Full citations for documents referred to in this responsiveness summary are provided in Chapter 4. 


\section{GENERAL ISSUES: COMMENT'S AND RESPONSES}

\section{Issue 1}

Comment. The RI/FS documents include a disclaimer in which it is stated that DOE does not assume any legal liability or responsibility for the accuracy, completeness, or usefulness of the information included in the documents. How can DOE proceed with this action when it does not stand behind the information supporting its selection?

Response. Inclusion of the disclaimer in these documents was an error. The DOE does indeed stand behind the information and analyses provided in the RI, BRE, and FS. This disclaimer is used in documents summarizing work sponsored by DOE that is experimental or developmental in nature; its purpose is to exempt DOE and its contractors from legal liability for research activities to allow new ideas and concepts to be explored without being restricted by legal constraints. These conditions do not apply to this RI/FS.

\section{Issue 2}

Comment. The proposed action entails temporary storage of the bulk wastes at the chemical plant area. How long is "temporary" storage?

Response. The quarry bulk wastes are scheduled to be in temporary storage for three to six years.

\section{Issue 3}

Comment. How do we know that temporary storage will not become permanent?

Response. The temporary storage facility will not be designed to meet permanent disposal requirements nor is there any consideration of ever upgrading it to meet such requirements. Permanent disposal requires separate processes of environmental compliance, regulatory concurrence, and public involvement. This does not mean that construction of a permanent disposal cell on-site will not be considered in the future; however, it does mean that temporary storage of the bulk wastes will not influence that disposal decision.

\section{Issue 4}

Comment. Rernoval of the quarry bulk wastes with temporary storage at the chemical plant area is only an interim action in the overall remediation of the Weldon Spring site. When will a decision on the permanent disposal of all site wastes be reached? 
Response. The DOE is currently preparing an RI/FS to evaluate alternatives for the permanent disposal of all wastes generated by remediating the Weldon Spring site. The analyses in that Rl/FS will include those required in an environmental impact statement (EIS) for compliance with the National Environmental Policy Act (NEPA). This integrated CERCLA/NEPA approach is being referred to as the RI/FS-EIS process. The RI/FS-EIS is being prepared consistent with EPA guidance, and a preliminary internal review draft will be available in late 1990. The RI/FS-EIS documents will be available for review by EPA Region VII, the state of Missouri, and the general public in 1991, and a joint EPA/DOE record of decision for this proposed action will be issued in 1992 .

\section{Issue 5}

Comment. The quarry bulk wastes should not be moved until a permanent disposal decision has been reached for managing all wastes from the Weldon Spring site and a disposal facility is ready to accept the wastes. This interim remedial action is not a wise expenditure of tax dollars.

Response. Delaying this interim remedial action would postpone the attainment of remedial action objectives at the quarry (e.g,, to respond to ongoing releases by removing the primary source of contamination from the quarry and to initiate necessary characterization activities). The preferred alternative can be implemented in a manner that will not endanger students and staff at Francis Howell High School or any other individuals in the area. The extensive monitoring program currently in place will be expanded prior to initiating the proposed action to ensure the health and safety of nearby residents and the environment.

The DOE is currently preparing an RI/FS-EIS to evaluate alternatives for the permanent disposal of all wastes generated by remediating the Weldon Spring site. Although the RI/FS-EIS will be available for public review and comment in 1991, the length of time to implement permanent disposal options will take several more years. Delaying the proposed removal of the bulk wastes would result in continued, uncontrolled release of contaminants to the environment in the quarry area. The proposed action is being taken at this time to respond to this release.

Although some additional cost will be incurred by placing the bulk wastes in temporary storage, most of the components associated with this action will be required whether the action is taken now or in the future. The wastes must be removed and characterized to permit an informed evaluation of various treatment options prior to final disposal. Hence, the incremental cost is a good expenditure of funds based on the considerable benefits associated with expediting the action, i.e., the proposed action will protect human health and the environment and support overall waste management decisions for the project. These (and other) reasons for conducting the proposed action are discussed in greater detail in the FS. 
Issue 6

Comment. Why not simply move the well field to ensure the safety of this source of potable water? This would be a much simpler and cheaper solution.

Response. There is currently no need to consider moving the well field or providing an alternative source of potable water because the water in this well field is not contaminated. Removing the source of potential threat to the well field is only one of the reasons for this action. The bulk wastes must be removed in order to perform detailed characterization of the wastes for evaluating appropriate treatment technologies and disposal alternatives. In addition, the wastes must be removed to allow for detailed characterization of the quarry area. Removal of the bulk wastes is responsive to the need to protect human health and the environment and also serves to protect an important natural resource (i.e., the groundwater in this area).

Issue 7 for disposal?

Comment. Will any wastes from other areas be brought to the Weldon Spring site

Response. The proposed action is limited to management of the quarry bulk wastes; management of all wastes from cleanup of the Weldon Spring site is the subject of a separate RI/FS-EIS process that is currently under development. There are no plans to bring wastes from other areas to the Weldon Spring site for disposal. The record of decision for remediation of the chemical plant area of the Weldon Spring site will address the scope of waste disposal and will address limitations on use of the Weldon Spring site for future actions, as appropriate.

\section{Issue 8}

Comment. The wastes should be sorted and containerized at the quarry prior to transport to the chemical plant area for temporary storage.

Response. This type of issue would typically be addressed during the engineering design phase of the project. However, DOE has reviewed this concept and believes it has merit. The approach currently being evaluated is to conduct basic sorting at the quarry, load the sorted wastes into containers such as large steel boxes, and transfer the containers to trucks for transport to the chemical plant area. At the chemical plant area, the containers will be unloaded and the wastes placed directly into controlled storage; the empty containers will be returned to the quarry for reuse.

This approach would tend to decouple the excavation, transportation, and unloading activities. For example, extra waste containers could be loaded at the quarry during a second shift or while wastes were being transported to the temporary storage area. 'Trucks could travel along the haul road in small convoys (i.e., three to six trucks) to the temporary storage area where the containers will be off-loaded. The wastes would 
subsequently be removed from the containers and placed into controlled storage, and empty containers loaded onto trucks for the return trip to the quarry. Such an approach could allow for the return trip to the quarry to be on the dedicated haul road. Plans for the haul road may need to be modified to include several turnouts wh' $\mathrm{ch}$, in conjunction with radio contact, would allow safe passage of truck traffic. This would eliminate all truck traffic on Route 94 .

\section{Issue 9}

Comment. Why is it necessary to move the wastes closer to Francis Howell High School for temporary storage? Why not take the quarry wastes somewhere else for disposal?

Response. No disposal facility is currently available for the quarry wastes. Furthermore, a permanent waste disposal decision is a very complex issue and will not be made for a few years. Therefore, the only alternatives at this time are to remove the quarry bulk wastes and temporarily store them pending a waste disposal decision or delay the quarry cleanup action. The DOE believes it is important to initiate the quarry cleanup action as soon as possible (see responses to Issues 5 and 6). The question then becomes where to store these wastes.

In addition to the fact that there is simply no other available space, there are several good reasons to temporarily store the wastes at the chemical plant area. On-site storage will ensure that no individuals are inadvertently exposed because access to the chemical plant area is controlled; also, the presence of on-site DOE and contractor staff will ensure continuous oversight. The wastes can be safely and expeditiously characterized to allow for an informed waste disposal decision to be made as soon as possible. Finally, the extensive monitoring capability available at the chemical plant area can be used to ensure the health and safety of nearby residents. This is the best way to store these materials in the near term.

Issue 10

Comment. There is insufficient engineering information on the proposed action to adequately assess the feasibility of its implementation. It is not possible to selert an alternative with the level of detail provided in the RI/FS documents.

Response. The level of detail provided in the RI/FS documents is consistent with that required by EPA for actions of this magnitude. Detailed engineering for this action cannot be initiated until the record of decision has been issued. However, the analyses presented in the RI/FS and supporting documents demonstrate that this action can be performed safely and in compliance with all applicable standards and regulations. This information is sufficient to allow for selection of an alternsilve.

The level of detail necessary to determine the engineding feasibility of this action is presented in tr.e preliminary engineering report supporting the FS. The design 
documents to be developed following issuance of the record of decision will focus on the physical aspects of this action -- such as equipment needs, operational reculrements, material handling, and cost. Planning related to dealing safely with the various types of contaminants and hazards that may be encountered will be presented in an operational environmental, safety, and health plan. The results of these two planning efforts will ensure that this action is implemented safely.

Issue 11

Comment. There is insufficient characterization data to adequately plan this action.

Response. A significant amount of information is available on the physical, chemical, and radiological characteristics of the bulk wastes from previous investigations. The results of these investigations, which are presented in the RI, are consistent with the disposal history at the quarry. This information is sufficient to design a safe plan for the removal, transport, and temporary storage of the bulk wastes.

It is possible that some unknown waste material was placed in the quarry. In designing the waste removal process, an observational approach will be used to deal with this possibility. In this approach, planning is based on avallable data and realistic assumptions concerning field conditions, and adjustments are made in the fleld as work proceeds. Deviations from expected conditions and mechanisms by which to identify their occurrence are defined, and plans are developed to address or mitigate adverse effects that result from these deviations. This approach ensures responsiveness to actual field conditions.

\section{Issue 12}

Comment. The quarry bulk wastes contain residual concentrations of trinitrotoluene (TNT), dinitrotoluene (DNT), and their decomposition products. Is there any possibility for an explosion to ocrur while the bulk wastes are being removed?

Response. The highest measured concentration of TNT in the bulk wastes is about 2\%. This value resulted from biase sampling in which areas of surficial discoloration were targeted in an effort to define the maximum concentrations. 'i'he measured value of $2 \%$ is well below the concentration that presents an explosive hazard during excavation (i.e., 12 to 15\%). The concentrations of DNT and decomposition products of TNT and DNT in the bulk wastes are much lower than the measured concentration of 'TNT. The proposed action has since been reviewed by Hercules, Inc., a company with extensive expertise in dealing with explosives. Their technical review concluded that the current plan is feasible and that an explosion is highly unlikely. However, the concentration of nitroaromatic compounds in the bulk wastes will be evaluated as the wastes are being excavated to ensure that there are no pockets containing much higher concentrations of TNT that could present an explosive hazard. 
Plans will be in place to deal with explosive concentrations of TNT in the unlikely event of such an occurrence.

Issue 13

Comment. Effective radon and dust control measures should be used to minimize atmospheric releases while implementing this action.

Response. Extensive radon and dust control measures will be implemented during all phases of this action that have a potential for creating airborne emissions. During excavation of the wastes, emissions will be controlled by water sprays, foams, and tarps, as needed. The wastes will be transported to the chemical plant area in trucks along a dedicated haul road. Current plans are to package the wastes in containers to ensure minimal releases. Dust control measures similar to those at the quarry will be used while unloading the bulk wastes at the temporary storage area. Finally, all wastes susceptible to windblown erosion or release of radon gas will be covered as soon as practical following placement in the temporary storage area. These measures will ensure minimal atmospheric releases of radon gas or contaminated dust from implementing this action.

\section{Issue 14}

Comment. It is essential that remedial actions at the Weldon Spring site be implemented in a manner that will not compromise the health and safety of the people of St. Charles County. A thorough environmental monitoring program should be put in place prior to initiating this action to ensure the health and safety of nearby residents and students and staff at Francis Howell High School.

Response. An extensive environmental monitoring program is currently in place at both the quarry and chemical plant areas. This program provides extensive information on the current status of these two areas. The monitoring program will be expanded at both the quarry and chernical plant areas prior to initiating the bulk waste remedial action. An operational environmental, safety, and health plan is currently being prepared to address the specific needs of this action. An array of air monitors will be placed at the temporary storage area and site perimeter to detect any airborne contamination that could impact Francis Howell High School. The health and safety of nearby individuals will not be compromised by the conduct of this action.

Issue 15

Comment. An emergency response plan should be developed prior to initiating this action to address actions that would be taken if there are any spills or natural disasters. This plan should address earthquakes, high winds, tornadoes, spills, and any other events that could cause large releases of radioactive and chemical coritaminants to 
the environment. The Francis Howell School District should be part of the planning process because of the close proximity of its elementary and high schools.

Response. The DOE will develop an emergency response plan to address credible emergenoy situations consistent with the hazards posed by the proposed action. This plan will identify measures to be taken in the event of a spill, transportation accident, or natural disaster. In developing this plan, DOE will involve the Francis Howell School District and local of flicials who would require notification or coordination in the event of an emergency. Removal of the bulk wastes will not begin until an emergency response plan is in place.

\section{Issue 16}

Comment. The ongoing environmental monitoring program at the quarry needs to continue without interruption before, during, and after removal of the bulk wastes. This is the only way to ensure the safety of the St. Charles County well field.

Response. The St. Charles County well field is being extensively monitored by federal, state, and local authorities. This monitoring indicates that the well field has not been impacted by contaminants migrating from the quarry. The DOE will increase its monitoring efforts during the bulk waste remedial action to ensure that this action does not result in contamination impacting the well field. Monitoring of the well field will continue following removal of the bulk wastes while studies are undertaken to evaluate the need for additional remediation of this area. Monitoring activities at the quarry will not be discontinued until all follow-on studies have been completed and any additional remedial actions have been implemented. Such future decisions will rely on input from EPA Region VII, the state of Missouri, and of ficials from St. Charles County.

Issue 17

Comment. Since the levels of radon are elevated at the quarry, why move these materials closer to Francis Howell High School and increase the risk to students from radiation exposure?

Response. Removal of the bulk wastes is being taken, in part, to control radon emissions from these materials. The radium-contaminated soils will be placed in controlled storage at the temporary storage area and covered with a liner that is very effective at reducing radon gas releases. Modeling studies presented in the FS indicate that the radon concentrations at Francis Howell High School resulting from this action would be inciistinguishable from background levels. The DOE will monitor for radon-220, radon-222, and their short-lived decay products at the temporary storage area, the site perimeter, and Francis Howell High School during implementation of the action and during the temporary storage period. This monitoring program whil allow for upgrading of radon emission controls, if necessary, to prevent impacts to the high school. 
Issue 18

Comment. Results of environmental monitoring activities need to be provided to the general public in a timely manner. The results of 1988 environmental monitoring activities were not issued until January 1990. The general public needs to be kept better informed, especially as the bulk waste remedial action proceeds.

Response. The 1988 environmental monitoring report was issued late due to the internal review process within DOE. The 1989 environmental monitoring report will be issued in the near. future. The DOE agrees on the need to provide environmental monitoring results in a timely manner and is currently developing a plan to issue the results of environmental monitoring on a more frequent basis. Any anomalous environmental monitoring iata associated with the bulk waste remedial action will be made available to local authorities and any potentially affected individuals as soon as possible.

\section{Issue 19}

Comment. The report recently released by the Committee on the Biological Effects of Ionizing Radiations (i.e., the BEIR V report) indicates that the biological effects of exposure to low levels of radiation are greate' than previously estimated. Are there likely to be any changes in the federal government limits for permissible levels of radiation exposure to workers or the general public as a result of this study? What impact do these results have on the proposed action?

Response. The recently issued BEIR V study presents a detailed description of current data on the health risks of exposure to low levels of ionizing radiation. This study estimates that the health risk is about three times greater than estimated in the previously issued BEIR III report. However, it should be noted that the data used to reach these conclusions have limitations, as noted in the BEIR V study. Assessment of the carcinogenic risks that may be assosiated with low doses of radiation were extrapolated from effects observed at doses larger than 10 rem delivered over a short period of time. In addition, it was necessary to use assumptions about the relevant doseeffect relationships and the underlying mechanisms of carcinogenesis.

Health hazar is associated with chronic exposure to low levels of ionizing radiation have been studied in areas such as those having high levels of background radiation, areas receiving fallout from nuclear weapons testing, and areas near nuclear installations; the data from these studies do not indicate an elevated level of cancer risk. Hence, it is still not possible to draw definitive conclusions of the cancer risks associated $v_{r}$ ith chronic exposure to low levels of ionizing radiation.

The permissible level of radiation exposure for workers is based on limiting their health risk to levels that are comparable to the occupational risks from other industries that are considered to be safe. The permissible level ( $5 \mathrm{rem} / \mathrm{yr}$ ) may be reduced as a result of recent studies indicating that the risk from exposure to low levels of ionizing radiation is higher than previously estimated. The DOE and other federal agencies are 
currently examining this issue. The radiation doses to workers who would implement this action would be considerably below current limits.

The results of the BEIR V study are not expected to result in significant changes in the permissible levels of radiation exposure to the general public or in DOE concentration limits for radionuclides in liquid or gaseous effluents. The risk factors presented in the BEIR $V$ report are consistent with those used by the EPA in developing revisions to the National Emission Standards for Hazardous Air Pollutants under Section 112 of the Clean Air Act for radionuclides and by the U.S. Nuclear Regulatory Commission (NRC) in developing revisions to Title 10, Part 20, of the Code of Federal Regulations (10 CFR 20) for permissible levels of radionuclides in air and water in controlled and uncontrolled areas. The DOE standards are consistent with those developed by the EPA and NRC.

A major element of DOE's radiation protection program for occupational and public exposures is the as low as reasonably achievable (ALARA) concept. Under the ALARA process, all exposures to radiation and all releases of radioactivity to the environment must be reduced to levels that are as low as reasonably achievable. The DOE is committed to this approach. The proposed action would not be impacted even if more stringent standards were in effect because the predicted levels of radiation exposure to workers and the public are well below applicable standards.

\section{Issue 20}

Comment. Transporting the wastes by truck from the quarry to the chemical plant area has the potential for spreading contamination to currently clean areas. How will this possible spread of contamination be controlled?

Response. The wastes will be transported to the chemical plant area in trucks that will travel at low speeds along a dedicated haul road. Current plans are to package the wastes in containers to ensure minimal releases during transport. The exteriors of the trucks will be surveyed for contamination before leaving the quarry and chemical plant area; any loose contamination will be removed before the trucks are allowed to exit these two areas. Finally, periodic surveys of the haul road will be performed to ensure that contamination controls are effective. If any contamination is detected on the haul road, the area will be cleaned up immediately and measures will be taken to prevent a reoccurrence. This approach will ensure that contamination is not being spread to the environment as a result of waste relocation.

\section{Issue 21}

Comment. As currently planned, trucks leaving the quarry would cross State Route 94 near the quarry and then proceed along a dedicated haul road to the chemical plant area. Empty trucks would return to the quarry using Route 94. The DOE should investigate further the use of grade separation (i.e., an underpass) at the intersection of State Route 94 and the haul road to avoid any crossing of Route 94 by trucks. In 
addition, plans should be developed to minimize or eliminate truck traffic on Route 94 during time periods that bus or student traffic are on this roadway.

Response. The DOE agrees that transportation safety is one of the most significant issues associated with this action. As presented in the FS, wastes would be loaded directly into trucks. In this approach, the rate of waste removal could be limited by the time required for a truck to travel to the temporary storage area and return to the quarry for another load. By staging the containers at the quarry, and using the trucks only to shuttle containers back and forth to the temporary storage area, the entire operation can sustain the extra time required for trucks to share the single lane haul road. To provide further flexibility, plans for the haul road could be modified to include turnouts which, in conjunction with radio contact, would allow safe passage of truck traffic. This would eliminate all truck traffic on Route 94.

In addition, discussions are currently taking place with the state of Missouri on the use of grade separation where the dedicated haul road crosses State Route 94 . This would eliminate all crossing of Route 94 by trucks. Use of grade separation would require reconstruction of a section of Route 94 . The decision on use of this option will be largely dictated by the cost of the reconstruction relative to that associated with other safety measures that could be used at this crossing (e.g., flagmen, traffic signals). The DOE will continue working with the state to resolve this issue.

Issue 22

Comment. Will this action have any impact on wildlife in the immediate area?

Response. Activities related to this action will destroy about 15 ha ( 37 acres) of vegetation at the quarry, along the haul road, and at the chemical plant area. Some small, relatively immobile wildlife will be lost, and other more mobile wildlife will be disturbed, displaced, and possibly lost during construction and operation. However, the overall impact will be very minor given the extensive amount of wildlife habitat in the surrounding area.

\section{Issue $\mathbf{2 3}$}

Comment. There has been a higher incidence of childhood leukemia in St. Charles County than that expected in the general population. It is imperative that this action be conducted in a manner to ensure that no additional cancers will result from removing the bulk wastes from the quarry and transporting them to the chemical plant area for temporary storage.

Response. The Missouri Department of Health's retrospective childhood leukemia study does not support the contention that there are elevated levels of childhood leukemia in St. Charles County. The study indicated an increased level of childhood leukemia cases during the period of 1975 through 1979 , but the incidence rate over the entire period of the study (i.e., 1970 through 1983) was not statistically 
different from that to be expected in the general population. The Department of Health was not able to establish a link between these leukemia cases and any specific cause; they specifically ruled out exposure to releases from the Weldon Spring site.

Even though the risks to the general public from this action are estimated to be very low, DOE, under its ALARA process, will ensure that the risks are reduced to extremely low levels. It is highly unlikely that there will be any health impacts associated with radiation exposure resulting from this action.

Issue 24 removed?

Comment. What will become of the quarry after the bulk wastes have been

Response. After the bulk wastes have been removed, detalled studies will be performed to evaluate the need for additional remedial action (such as the removal of residual materials from the cracks and fissures in the quarry and the remediation of contaminated groundwater). The water treatment plant at the quarry will continue to operate to keep the quarry pond from refilling. After all necessary remedial actions are complete, the quarry area will be stabilized. Plans for stabilizing this area will be prepared cooperatively with state of Missouri agencies such as the Missouri Departments of Natural Resources and Conservation to ensure that future uses of the quarry area are consistent with those planned for the surrounding Weldon Spring Wildlife Area.

Issue 25

Comment. How do we know that sufficient funds will be available to complete all necessary remedial actions.

Response. Funding for remediation of the Weldon Spring site is provided by Congress on an annual basis. There is no guarantee that all required funds will be made avallable each and every year; however, cleanup projects such as that at the Weldon Spring site are currently top priority activities within DOE. In addition, because the site is on the National Priorities List (NPL), EPA Region VII is responsible for ensuring the adequacy of the cleanup. Representatives from EPA Region VII have made it very clear that they will not delist. the site from the NPL until they are satisfled that all required remedial actions have been completed.

Issue $\mathbf{2 6}$

Comment. The proposed plan states that Alternutive 5 is praferred by DOE. Has DOE already decided on implementing this alternative? 
Response. The DOE has not yet reached a decision on implementing Alternative 5. However, this alternative is preferred by DOE. A jolnt EPA/DOE record of decision will be issued this year documenting which alternative will be implemented.

\section{Issue $\mathbf{2 7}$}

Comment. The DOE has apparently already concluded that truck transport of the bulk wastes is the preferred mode of transportation. Additional consideration should be given to using the existing rail spur between the quarry and chemical plant area.

Response. The existing rail spur between the quarry and chemical plant area is in a state of disrepair and would require a significant amount of effort (and cost) to upgrade for use. The results of a recent detailed cost estimate indisate that the rail option would cost about $\$ 1$ million more than the haul road option. In addition, this rail spur crosses State Route 94 three times between the quarry and chemical plant area. Each crossing presents a safety concern. The wastes can be safely and efficiently transported by truck along a dedicated haul road that will be constructed using portions of the existing rail spur. This dedicated haul road will cross State Route 94 only once (near the quarry). Discussions are currently taking place with the state of Missouri on the use of grade separation where the haul road crosses Route 94 . This would eliminate any crossing of Route 94 by trucks.

\section{Issue 28}

Comment. The sorting pad at the temporary storage area should be completely enclosed and ventilated to minimize airborne releases of contaminants. In addition, the entire quarry area should be enclosed during removal of the bulk wastes.

Response. The need for an extensive sorting pad at the temporary storage area is being reevaluated because the current plan is to conduct basic waste sorting at the quarry. Although some sorting may still be required at the temporary storage area, enclosing the sorting pad with an engineered structure is probably unnecessary; however, this consideration will be evaluated as engineering design proceeds.

Enclosing the entire quarry during excavation of the bulk wastes was considered in the preliminary engineering report and rejected due to its high cost. In addition, there is simply no need to enclose the quarry to remove the wastes safely. Radon and dust suppression measures will be implemented to ensure that releases of hazardous contaminants to the atmosphere will be low and not present a health risk to nearby individuals. 


\section{WRITTEN COMMENTS AND RESPONSES}

Comment letters on the RI/FS documents were received from the individuals listed in the following table. Each of these letters has been assigned an identification code according to date of receipt, and specific issues within each letter have been identified with a number. For example, the earliest letter recelved is Letter A; issues (comments) identified within Letter $A$ are labeled $A-1, A-2$, and so forth; and the respective responses to these comments are labeled Response $A-1$, Response $A-2$, and so forth. A copy of each letter is reproduced in this section, and the responses to identifled comments are presented on succeeding pages.

\begin{tabular}{|c|c|c|}
\hline $\begin{array}{l}\text { Letter } \\
\text { Code }\end{array}$ & Commenter & $\begin{array}{l}\text { Page } \\
\text { No. }\end{array}$ \\
\hline A & $\begin{array}{l}\text { Ted House, State Representative-20th District, Missouri } \\
\text { House of Representatives, Jefferson City }\end{array}$ & 16 \\
\hline B & $\begin{array}{l}\text { Jack Beuchner, U.S. Congressional Representative, Missouri. } \\
\text { Second District, House of Representatives, Washington, D.C. }\end{array}$ & 18 \\
\hline $\mathrm{C}$ & Alberta Toedebusch, Defiance, Missouri & 20 \\
\hline D & Mrs. Leo Drey, University City, Missouri & 22 \\
\hline E & $\begin{array}{l}\text { Patrick S. LeClaire, Market Manager, Environmental Logistics, } \\
\text { Burlington Northern Railroad }\end{array}$ & 40 \\
\hline F & L. Rao Ayyagari, St. Peters, Missouri & 48 \\
\hline G & Linda M. Hoenig, St. Peters, Missouri & 60 \\
\hline H & $\begin{array}{l}\text { Meredith Hunter Bollmeier, St. Charles Countians Against } \\
\text { Hazardous Waste, Technical Assistance Grant Project Manager }\end{array}$ & 68 \\
\hline I & Ceorge A. Farhner, St. Charles, Missouri & 76 \\
\hline
\end{tabular}


Letter $A$

CAPIOL OFFIOE

State Capltol - Room 115.G

House Post Ollice

Jefferson City, MO o5, 101

(314) 751.8437

Maroh 26, 1990

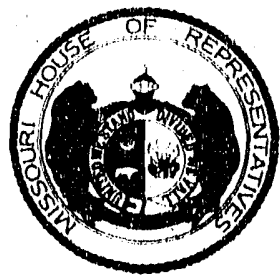

TED HOUSE

STATE REPRESENTATIVE - 2Oth DISTRICT home acomss

14.37 Sumneriuguate Penkwedy st. Chatrles. MO 6.3303

(31i) $94911 \%$

Mr. Steve MoCracken

Project Manager.

Weldon Springs Site Remedial Action Projeat

7295 Higliway 94 South

St. Charles, Missouri 63303

Dear steve:

Thanks so much to you and Jim and the other members of your staff for the detailed briefing on the Weldon Spring Quarxy Cleanup project last week. It was a pleasure to meet with you and to recelve the information which you provided.

I will be unable to attend the public hearing scheduled for Marah 29 , 1990, in Wentzille on the proposed removal and oleanup of the

A-1 contents of the quarry. Please announce at the hearing and note for the record my continued strong concern that the treatment and discharge of the water and the removal and storage of the bulk waste be conducted in a manner which will pose no danger to the area residents, the students, and staff of Francis Howell High school, or any passersby, or any other person.

It is essential to the health and safety of the people of st. Charles County that the St. Charles County Well fileld be closely monitored for migrating contaminants and that the items removed from the quarry be stored in a manner which poses no health risk.

A-2 $[$ I agree that the quarry clean-up does need to proceed even though no permanent storage site has been arranged, however. I wish you and the Department to consider the permanent disposal of this material as soon as possible.

I stand ready to be of assistance to you any time I may help to clean up this site in the quickest and safest mannex.

Very truly yours,

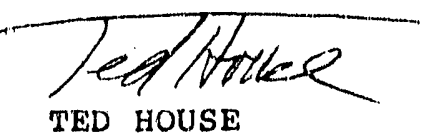

STATE REPRESENTATIVE

TCH/CL 


\section{Response A-1}

This interim remedial action is being taken to respond to ongolng releases of contaminants into the environment, which ourrently occur via uncontrolled airborne emisslons and leaching to soll and groundwater. Releases from the quarry bulk wastes can be much more effectively controlled if the materials are stored in an engineered facility at the chemical plant area. The ungoing environmental monitoring program indicate: that the St. Charles County well fleld is not being Impacted by current releases to the nearby groundwater. This monitoring program will be inoreased both in the quarry area and in the vicinity of the chemioal plant area to ensure that implementing this action does not adversely affect the health and safety of nearby residents, students and staff of Francis Howell High School, passersby, workers, or any other individuals in the area.

The first step in remediating the quarry is management of the surface water currently in the quarry, whlch is radioactively and chemically contaminated as a result of leaching from the bulk wastes. An engineering evaluation/cost analysis (EE/CA) report was prepared to evaluate alternatlves for managing this water. The response alternative selected as a result of the EE/CA process, which included public review and comment, was to treat the contaminated water and discharge it to the Missourl River in compllance with a permit issued to DOE by the Missouri Department of Natural Resources. The health and safety of the public will be ensured by treating the water to very stringent standards and guidelines prior to release.

Management of the bulk wastes constitutes the second step in remediating the quarry. As currently proposed, the wastes will be removed from the quarry and transported to the chemical plant area where they will be safely stored. The DOE is committed to conducting this action in a manner that will not compromise the health and safety of nearby individuals. The DOE will evaluate the need to perform additional remedial actions at the quarry area following removal of the bulk wastes. The DOE will involve EPA Region VII, the state of Missouri, and officials from St. Charles County in these decisions.

\section{Response A-2}

The DOE is currently preparing an RI/FS-EIS to evaluate alternatives for the permanent disposal of all wastes generated by remediating the Weldon Spring site. This RI/FS-EIS is being prepared consistent with EPA guldance, which requires a thorough review of alternatives for this action. The RI/FS-EIS is being prepared as expeditiously as possible and will be avallable for public revlew and comment In 1991 . 


\section{Letter B}

JACK BUECHNER

SECOND DISTHICT, MISBOUMI

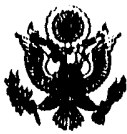 \\ Congress of the Anited States \\ Fouse of Kepresentatibes}

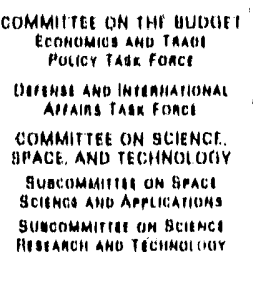

COMMITTE ON THE UUDOSE policy tadk foace

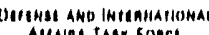
COMMITTEE ON SCIENCE. BPACE. AND TECHANOLOCIY scientia allo Aprlliations

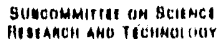

Marah 29, 2990

Mr. Steve Mccracken

Profect Manager

Dept. of Energy

7225 HWy. $94 \mathrm{~s}$.

Weldon Springs, Missourt 63303

Dear Mr. Mocradken:

Thank you for the opportunity to preview the waste cileanup presentation scheduled for the Maroh $29 \mathrm{ch}$ public meeting. Thls is a hlghly sensitive issile as I'm sure you well know. I cammend the D.0.i. on their efforts up to this point.

Howevar, I have one major concern regarding the one time finding of: contaminated soll that was claimed to have been measured in error.

B-1 There is no room for error in a bulk waste cleanup project, especially when you are dealing with the drinking water supply supporting thousands of altizens. We must continue well monltoring of the region south of the slough and make every effort to remove the toxlc waste in a timely fashion. Your pointe regarding the characterlzation of the waste

B-2 material makes tremendous sense in the D.O.E.' $\mathbf{s}$ efforts to eliminate contamination. I have one question concarning the time frame surrounding this characterlation process and at what point a permanont Iite can be antioipated. The bulk waste removal plan appears to be woll thought out and must remain that way to insure the continued support of state agencies and the citizens of st. Charles county.

I support the efforts of toxio waste cleanup and would appreciate bolng keop abreast of the operation. Thank you for the conalderation."

JWB/WJe

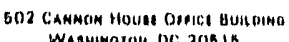
WASHEMOHOH, DC 2051
(202) $275+2601$

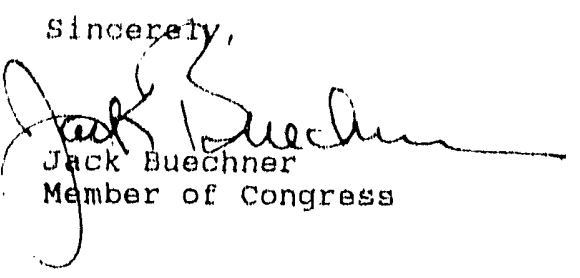

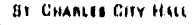
200 lantil socono simul Si Ciraniri, MO O.3301 


\section{Response B-1}

The DOE agrees with the need to proceed expeditiously, but carefully, with this activity. Detalled engineering and environmental monitoring plans will be prepared prior to excavation of the bulk wastes to ensure that this activity will be done safely. The DOE intends to expand the groundwater monitoring program in the quarry area to ensure the safety of the St. Charles County well fleld.

\section{Response B-2}

Characterization of the bulk wastes will occur very soon after their placement into temporary storage at the chemleal plant area. Plans wlll be based, in part, on information developed from the bulk waste excavation activity. Plans and schedules for waste characterization will be developed prior to initlating bulk waste removal. The DOE is currently preparing an RI/FS-EIS to evaluate alternatives for the permanent disposal of all wastes generated by remediating the Weldon Spring site. The RI/FS-EIS is being prepared consistent with EPA guidance, whlch requires a thorough review of alternatives for this action. The RI/FS-EIS is being prepared as expeditiously as possible and will be available for public review and comment in 1991. 


\section{Latter C}

Apri1 2, 1990

Mr. Steve MoCraoken

Project Manager for the Ene:gy Dept.

Weldon spring stte Remedial Action Project

Route 2 , Highway 94 south

St. Charles, Missouri 63303

\section{Kind Sir,}

I have been a resident of the western part of st. Charles co. all my $11 \mathrm{fe}$, and have been interested in what has been happening here; and I am stjll very much interested.

I remember when the land was taken over by the Federal Government in 1940 for the 'TN' Plant; when the site was nominated as a probable location of the Atr. Force Academy; how thankful we were when the bullding of a plant to manufacture Agent Orange was scrapped; when the site was used for the refining of uranium and thorlum; and the area was the disposal site for radioactive waste from Mallinckrodt Chemlcal Company.

Likewise, I am interested in the clean-up of the Weldon spring plant. As a restdent of st. Charles Co (and espectally the C-1 Clean-up area); and also a tax-payer, permit me to of fer a suggestion. I feel it to be practical to first decide where the permanent site for the storage of the waste is to be located; provide that permanent facllity, and then move the waste to the permanent facility. Thus much tax-payer money and much man-power would be saved; and certalnly decrease the risk of contamination to Francis Howell High School and also the surrounding area.

Since it is not planned to begin moving material from the quarry until 1992, surely with today's modern and sophisticated machinery and know-how; the bullding of a permanent facllity could be accomplished by that time.

I hope you will give this suggestion your utmost consideration. I would appreciate the favor of a reply.

Respectfulily,

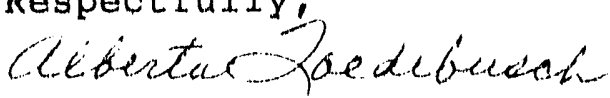

Alberta Toedebusch

4600 Highway $D$

Deftance, Missourt 63341 


\section{Response $\mathrm{C}-1$}

Delaylng this interim remedial action would postpone the attainment of romedial action objectives at the quarry (e.g., to respond to ongolng releases by removing the primary source of contamination from the quarry and to initlate necessary characterization activities). The preferred alternative oan be implemented in a manner that will not endanger students and staff at Franols Howell High Sahool or any other individuals in the area. The extensive monitoring program currently in place will be expanded prior to Initlating the proposed action to ensure the health and safety of nearby residents and the environment.

Although some additional cost and manpower will be incurred by placing the bulk wastes In temporary storage, most of the components assoclated with this action will be requiled whether the action is taken now or in the future. The wastes must be removed and characterized to permit an info:mud evaluation of treatment options prior to flial disposal. Hence, the incremental cost and effort !s a good use of resources based on the considerable beneflts assoclated with expediting the actlon, l.e., the proposed action will protect human health and the environment and support overall waste management declsions for the projeat. These (and other) reasons for conducting the proposed action are discussed in greater detall in the F'S.

The DOE is currently preparing an RI/FS-EIS to evaluate alternatives for the permanent disposal of all wastes gerierated by remediating the Weldon $S_{\mathrm{r}}$ ring site. Although the RI/FS-EIS will be avallable for publle revlew and comment in 1991 , the length of time to Implement permanent disposal options will take several more years. Delaying the proposed removal of the bulk wastes would result in continued uncontrolled releases of contaminants to the environment in the quarry area. 'The proposed action is being taken at this time to respond to this release. 
lutter D

Mrsi Leo Drey

818 Wuat Point Avenut

Univeruity Clity, MO 63130

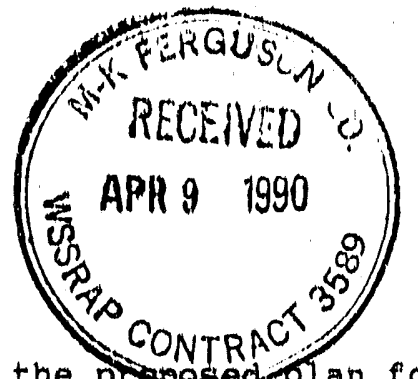

Apri1 5, 1990

Comments and questions on the propesed fian for the Weldon spring Quarry

Bulk Waste Rewovel interim remedial action. Presented in part at the Department of Energy/Environmental protection Agenoy publia meeting on March 29, 1990, at the Ramada Inn in Wentzvilla, Missouri.

[The following comments and questions which I an submitting for the record are a combination of those I was given tine to read at the March 29 publito meeting and some supplemental ones.]

D-1 [ 1 am here first to make it olear, for the record, that the citizens who partiolpatied in the appeal of the National pollutant Disoharge Elimination system permit for the oluarry water agreed not to continue our protest of the proposed release of the treated water into the Missouri River only with respect to the amount and types of informational mendtering the Department of Energy would be required to perform. The Mlssourl Department of Natural Resources had determined that we were not allowed to pursue any of our other concerns, such as whether this water should be roleased into $\mathrm{st}$. Loulg County's drinking water supply ... that is, Into the Missourl River about 10 miles upstream from the $\mathrm{St}$. Louis County water Company's main intake struoture. We also never disoussed the question of whether the bulk wastes should be excavated and removed from the Quarry before the Quarry pond water begins to be pumped out, or aftor.

We remain conoerned about the continuing supply of water that will need to be treated - and that could then end up in our st. Louis drinking water supply - such as the contaminated ground wator from the adjacent and underlying vioinity areas that will flow into the Quarry as the pond water is removed; the rainwater and snow that will percolate through the wastes; and the processing water, such as from the highpressure hosing of the Quarry walls (for radon and dust control), and from the dewatering of the bulk wastes after they are excavated and prior to their transpurt four miles to the Temporary storage Area (ISA) at the abancloned Chemioal plant.

obviously the Quarry inust be cleaned up. However many questions remain unanswered:

D-2 1 . How can responsible decisions about water treatment technologies and bulk waste excavation and storage be made with only the minimal amount of monltoring data you have avallable? We have no indication that anyome realiy knows the quantity of radioactive 1sotopes in the Quarry Pond water - or in the bulk wastes. Until extensive and, in fact, expensive isotoplc analyses are performed of the Quarry pond water and groundwater, it seems premature and unscientific to design the water treatment plant. How san anyone know which water treatment technologies, if any, will be effective in removing all the radioactive and other hazardous pollutants if a full characterlation of those 


\section{Response D-1}

The RI/FS is limited to management of the quarry bulk wastes. An EE/CA report Issued in January 1989 evaluated alternatives for management of surface water in the quarry. The response alternative selected as a result of the EE/CA process, which Included public revlew and comment, was to treat the contaminated water and discharge it to the Missouri River in compliance with a permit issued to DOE by the Missouri Department of Natural Resources. The health and safety of the public will be ensured by treating the water to very stringent llmits prior to release.

The quarry water treatment plant wlll be used to treat contaminated water resulting from the bulk waste remedial action. Sources of contaminated water include (1) surface runoff from the quarry and the Immediate vicinity of the treatment plant (much of which will flow to the plant's equalization basin while the wastes are being removed), (2) water used to decontaminate equipment at the quarry, (3) water used to wash down exposed rook surfaces, and (4) incldental volumes of wastewater generated by support aotivities.

The treatment plant wlll also be used to treat surface water inflows to the quarry following removal of the bulk waste to keep the quarry pond from refilling. Releases of treated water to the Missourl River will be in compliance with the perr it issued to DOE by the Missouri Department of Natural Resources. The treatment plant could also be used to treat contaminated groundwater if such action is deemed necessary in the future. The discharge limits are protective of human health and the environment. The potential health risks to downstream consumers of Missouri River water are very low.

\section{Response D-2}

There is sufficient information on the radioactive constituents in the quarry pond and in the bulk wastes to proceed with design activities. The chemical and physical characteristics of the contaminants, which are well known, are the important parameters for treatment plant design because these characteristics dictate which treatment technologies will be effective. The water treatment plant will utilize standard technologies to remove the hazardous chemical and radioactive constituents. The safety of this system will be ensured by testing the treated water for compliance with the requirements of the discharge permit prior to release to the Missouri River. Any water that is not in compliance with this permit will not be released but will be recycled through the plant until the requirements are met. Batch testing and release of the treated water will ensure that there are no significant risks to downstream users of this water. 
D-2 pollutants is not available? As a st. Louisan living downstream, I remain extremely concerned.

D-3 2. How can anyone plan adequately for the removal, transport and interim storage of the bulk wastes when inadequate data are available on the bulk wastes, as well. To quote in an abbreviated form from page 6-10 of the Feasibility study: "Drilling. . . would be extremely difficult. . . representative sampling is infeasible. . ."

D-4 $[3$. Has there been an explosives expert who has had input into this whole plan of excavation? Has he or she determined if the TNT in the Quarry soil is in high enough concentrations for there to be a detonation? Has a contingency plan been drawn? Could the 2, 6 DNT -which is a potent carcirogen -- volatilize when exposed to the water that is to be sprayed in the Quarry for dust control during excavation and that is to be used for the high pressure hosing of the walls?

As stated in the remedial investigation and feasibility study reports, the wastes in the Quarry have not and cannot be fully characterized at this time due to difficulties in sampling. Therefore it should not be presumed that the concentrations of TNT, DNT or TNB are below the level of concern for detonation potential. There is insufficient evidence to claim that a maximum concentration of 28 INT exists in the soil at the Quarry; much higher concentrations may be present.

Because of the large number of unknowns and the corresponding high degree of uncertainty, the DOE should provide a more thorough discussion of this uncertainty and the associated risks. Supporting documentation and references should be provided to substantiate the claim made at the public hearing on March 28 that a detonation potential does not exist at the Quarry. The DOE has not provided any evidence that an explosives expert has been directly involved in identifying, selecting, or evaluating the alternatives for the Quarry bulk waste. Given the uncertainty and potential hazards, a more comprehensive evaluation of the problems and risks associated with TNT and DNT and their potential transformation products should be provided; references and expert testimony should be included in the response.

D-5 [4. Where do you expect to dispose of the radioactive resins that will accumulate during the operation of the Quarry water treatment plant? Are these concentrated wastes to be stored on the asphalt pad?

D-6 $[5$. Has any evidence been collected as yet that indicates whether any of the contaminated groundwater has migrated south of the slough near the Quarry? How far is the plume moving each year? At what depths below the surface are you extracting water for monitoring? What precautions are you taking to make sure that water samples are being extracted from a range of depths -- such as, from the top of the aquifer where the contamination level is likely to be highest -- and to make sure that each water sample is extracted from a discrete stratum so that less contaminated water from a different depth is not also present in 


\section{Response D-3}

A significant amount of information is available on the physical, chemical, and radiological characteristics of the bulk wastes as a result of previous investigations; the results of these investigations are presented in the RI. The types of contaminants and their concentrations are consistent with the disposal history at the quarry. This information is sufficient to plan for the removal, transport, and temporary storage of the bulk wastes.

It is possible that some unknown waste material was placed in the quarry. In designing the waste removal process, an observational approach will be used to deal with this possibility. In this approach, planning is based on available data and realistic assumptions concerning field conditions, and adjustments are made in the field as work proceeds. Deviations from expected conditions and mechanisms by which to identify their occurrence are defined, and plans are developed to address or mitigate adverse effects that result from these deviations. This approach ensures responsiveness to actual field conditions.

Detailed characterization of the bulk wastes will be performed after the wastes are placed in temporary storage at the chemical plant area. The results of this detailed characterization will be used to evaluate various treatment technologies for these wastes prior to their disposal.

\section{Response D-4}

Expert input with regard to explosives contamination is being solicited consistent with the level of detail required for each phase of project planning. Representatives from the U.S. Department of the Army, who are familiar with the Weldon Spring site and who have expertise in removing wastewater lines contaminated with explosives, were consulted during development of the RI/FS. The U.S. Army Toxic and Hazardous Materials Agency provided documents related to dealing with explosive materials, such as the report entitled Testing to Determine the Relationship Between Expl $r$ sive Contaminated Sludge Components and Reactivity prepared by Arthur D. Little, Inc., in 1987. This report describes the results of laboratory tests to determine the range of concentrations (i.e., 12 to $15 \%$ ) that present explosive hazards during excavation activities. As the project progresses into the conceptual and detailed design phases, additional expert input and review will be provided. For example, the project recently obtained the services of Hercules, Inc., a company known for their expertise in dealing with explosives. This company is providing technical reviews, safety assessments, and contingency scenario analyses to facilitate development of conceptual design and safety

plans. Their technical review of the proposed action concluded that the current plan is feasible and that an explosion is highly unlikely.

No appreciable volatilization of $2,6-\mathrm{DNT}$ or other nitroaromatic compounds present in the quarry bulk wastes is likely during water spraying operations. These compounds have very low vapor pressures and therefore do not readily evaporate in to the air. Water spraying will, in fact, reduce the emissions of nitroaromatic compounds that would otherwise be present during the excavation operations. 
The highest measured concentration of TNT in the bulk wastes is about $2 \%$. This value resulted from biased sampling in which areas of surficial discoloration were targeted in an effort to define the maximum concentration. The project will not, however, rely solely on existine characterization data. An observational approash will be instituted during remediation. i'his approach was developed by geotechnical engineers in performing subsurface foundation work and is a well accepted mechanism for managing uncertainty. The EPA supports this concept for rernedlating hazardous waste sites such as the Weldon Spring quarry. The method will be described in detail in design documents but, very simply, it consists of (1) conducting design based on the most probable set of field conditions; (2) identifying all reasonably foreseeable deviations; (3) establishing field mechanisms to determine if a deviation is occurring; and (4) developing contingency designs and controls to mitigate any adverse impacts associated with the respective field occurrence. This provides a structured approach to managing uncertainty and will allow the work to be performed safely and in a manner that will protect human health and the environment.

\section{Response D-5}

Wastes associated with operation of the quarry water treatment plant will be packaged and placed in the quarry for temporary storage; these wastes will subsequently be removed and stored in the drum storage area at the chemical plant area. Any wastes generated from operation of the water treatment plant following removal of the bulk wastes from the quarry will also be transported to the chemical plant area for storage. Disposal decisions for these wastes will be incorporated into the RI/FS-EIS currently being prepared, which addresses remediation of the chemical plant area of the Weldon Spring site.

\section{Response D-6}

Groundwater south of Femme Osage Slough is not currently contaminated as a result of contaminant migration from the quarry. Slightly elevated uranium concentrations have been detected in monitoring well $\mathrm{RMW}-2$. The cause of these elevated levels is not known. However, these levels have been stable (i.e., there has been no upward trend) and they are below levels of concern for human health and the environment. In addition, the 1984 environmental monitoring report indicated an elevated concentration in one well south of the slough. The reported value $(402 \mathrm{pCi} / \mathrm{L})$ was the average of two values -- one less than the detection limit and one of $804 \mathrm{pCi} / \mathrm{L}$; the latter value has been determined to be erroneous. Previous and subsequent sampling indicates background concentrations of uranium.

The plume does not appear to be migrating southward. Current understanding of the situation indicates that contaminated groundwater is discharged to Femme Osage Slough. Groundwater both north and south of the slough is monitored at several depths. Monitoring wells south of the slough monitor groundwater both potentially migrating under the slough and originating from the slough. All wells are completed and purged in accordance with current EPA guidelines for groundwater monitoring. 
D-6 the column of water extracted, thereby potentlally diluting the sample and thus distorting the findings?

D-7 [ 6. Have you estimated the probabllity of a tornado's having a direot hit at the chemical plant site -- that is, at the site of the proposed temporary storage pad -- over the next 5 or 10 years when the pad is to be used?

The probability of a direct hit by a tornado at the weldon spring site during the 10 year period the Quarry waste is to be stored at the Temporary Storage Area should be presented in the Feasibility study. The risk to human health and the environment from the dispersal Lof contaminated material from a toinado should be described.

D-8 Alternative methods for storing the Quarry materials, such as in drums, containers or under a weighted plastio cover as proposed, should be evaluated on the basis of risk minimization, effectiveness, and cost, and this evaluation should be presented in the feasibility study.

The public should be made aware of your rationale for selecting the plastic cover alternative when other methods for storage of the Quarry waste, especially the fine-grained solis and sediments, are available which could reduce the risk of wind dispersal. Of special concern is the potential impact from the widespread distribution of thorium-contaminated solls. Since this could result in the evacuation of people from their homes and businesses for tens of square iniles and make remediation much more difflcult and costly, the DOE should provide a detailed explanation of 1 ts decision in selecting the proposed method for waste storage at the TSA. The DOE should also specify any guidelines or rules regarding risk acceptability that were used in this analysis.

D-9 [ 7. Is there to be a dike constructed and maintained around the temporary storage asphalt pad so as to contain any runoff?

D-10 [ 8. According to page 10-2 of the Feasibility study, the bulk waste may be stored on the asphalt pad for up to 10 years. What are the DOE's plans for the final disposition of this material? According to the Final Environmental Impact Statement published in February 1987, the DOE was expecting to establish a permanent disposal cell at the chemical plant site. Is this currently the preferred alternative? How confident are you that you could build a permanent cell on this site that would meet federal regulations (such as the Superfund, Resource Conservation and Recovery Act, and Department of Energy regulations) and state regulations?

(My oral testimony was interrupted at this point. At the start of my testimony I had offered to read only as many of my prevared questions, and sub-questions, as I could fit into 5 minutes. I vas notified that my time was up when I had gotten to this point in my 8 th question. When 


\section{Response D-7}

The probabillty of a tornado striking the chemical plant area in any one year is estimated to be about 0.002 . The probabillty of a tornado strike during the three to six years the wastes would be in temporary storage would therefore be 0.006 to 0.012 . If a tornado were to hit the temporary storage area, materlal in storage could be dispersed off-site, which would result in members of the general public incurring radiation doses. However, the risk to nearby individuals from radiation exposure would be much lower than that from the physioal hazards assoclated with a tornado strike.

The DOE will prepare an emergency response plan prior to inltiation of this action. In developing this plan, DOE will involve the Francis Hovell School District and local officials who would require notifioation or coordination in the event of an emergency. The DOE will not initiate this interim remedial action until an emergency response plan has been developed to ensure the health and safety of nearby individuals under credible conditions, including tornadoes.

A tornado strike could occur at any time. A tornado hitting the quarry in its current condition would result in the dispersal of material into the nearby environment. Similarly, a tornado strike at the raffinate pits could result in the spread of contamination off-site. This emphasizes the need to clean up the entire site as socn as possible and to properly dispose of all contaminated materials. This is the best solution to safeguard against tornadoes.

\section{Response D-8}

The feasibility of sorting and containerizing the waste prior to transport to the chemical plant area was reevaluated; this approach has been determined to be preferable. In this approach, the wastes will be sorted and packaged in containers such as large steel boxes and transported to the chemical plant area in trucks along a dedicated haul road. The containers will be unloaded at the temporary storage area and the wastes placed directly into controlled storage. There are currently no plans to store these wastes in containers. Detalled characterization of the wastes cannot be performed effectively if they are stored in containers at the temporary storage area. Materials subject to wind erosion and radon emissions will be covered to minimize atmospheric dispersal.

The risk from wind dispersal of these materials will be minimal. There are no conceivable circumstances that could require the evacuation of people from their homes and businesses for tens of square miles. The safety of this action will be verifled by a thorough environmental monitoring program that will be conducted before, during, and after completion of the action. An operational environmental, safety, and health plan is being prepared for this action. In addition, an emergency response plan will be prepared to detail the measures to be followed in the event of unforeseen circumstances. This plan will be prepared utilizing input from the Francis Howell School District and local emergency response officials. This action will not be initiated until an emergency response plan is in place. 
In accordance with CERCLA requirements, detalled engineering for this action will not be initluted until the record of decision has been issued. The exact procedures to be used for excavation, transport, and storage of these materials will be defined during detalled engineering. No deslgn modifications will be made, however, that would be less protective than the scenarlos presented in the RI/FS documents. The analyses provided in the FS indicate that the risks to the general public from implementing this action will be very low, at or below those ldentifled by the EPA as being of conoern (1.e., $1 \times 10^{-4}$ to $\left.1 \times 10^{-7}\right)$. The risk from temporary storage of the wastes will also be very $17 w$.

\section{Response D-9}

A surface water runoff collection system will be an Integral component of the temporary storage area. Surface water runon to the temporary storage area will be controlled by diversion ditches surrourding the area. Storm-water runoff and leachate from within the temporary storage area will draln by ditches and swales to collection ponds located within the temporary storage area. This water will be treated in the water treatment plant to be constructed at the chemical plant area prior to discharge. A dike around the temporary storage area is not needed to contain runoff.

\section{Response D-10}

The DOE is currently preparing an RI/F'S-EIS to evaluate remedial action alternatives for the chemical plant area of the Weldon Spring site. This RI/FS-EIS is being prepared in place of revising the draft EIS that was issued in February 1987. The RI/FS-EIS will be available for public review and comment in 1991. A major component of the RI/FS-EIS is an evaluation of alternatives for the permanent disposal of all wastes generated by remediating the Weldon Spring site. On-site disposal of these wastes is one alternative that is being evaluated. An evaluation of applicable or relevant and appropriate requirements (ARARs) is a key element of the RI/FS-EIS process. All potential state and federal ARARs will be evaluated and reviewed by DOE, EPA Region VII, and the state of Missouri. The selected alternative must satisfy all pertinent regulatory requirements. 
D-10|I asked for another minute and a half to finleh, the moderator sald no. Would the choldo of this site be affected by the state's prohibition against siting a hazardous waste landf111 in a kargt terrain? That 19 , has the state given the DOE any assurance that it would approve this karst terrain as a permanent landelil site?

D-11 9. Are you planning to place a soll cap over the wastes (uncler the plastic cover) in the Temporary storage Area in order to reduce the release rate of the radon, which will continule to be emitted for hundreds of thousands of years? If so, how deep have you estimated the soli dap wili have to be in ordex to keep the radon release rate within the EPA's permissible standard? How an you predlat the height of the cap if you do not as yet: know the urarilum and thorium oonoentration levels of the Quarry bulk wastes?

D-12 [ 10. What are the highest levels of gamma radiation to which you expect the remediation workers to be oxposed during the exhumation, and during and after the consolidation of the wastes? Will protective olothing be provided that can shield the workers agalnst penetrating gamma radiation? Will masks be provided to protect against the Inhalation of alpha- and beta-emitting dust partioles? Are personnel masks available that technologically can screen out radon gas?

D-13 11. Do you expect any changes in the federal government's permissible levels of radiation to whioh workers will be allowed to be exposed as the result of the recently released report of the committee on the Blological effects of Ionizing Radiations of the National Research Councli, namely, the BEIR V report (Decemter 1989)? Do you expect any changes in the concentration levels of radionuclides the federal government will allow in liquid and gaseous releases to the environment, either onsite or offsite? Have analyses been made of how more stringent standards in either the workplace or in the environment could affect the proposed Quarry bulk waste interim remedial action plan?

D-14 12. Regarding the following answer in your "Informational Bulletin": "Contamination will not reach the school, therefore the students and staff will not be in any danger.": How can you accurately estimate the future rlsk to high school students and staff at this time from exposure to radioactive dust and radon gas emissions from the proposed 'remporary Storage Area, approximately a mile from the high school, when you do not know as yet the quantity or exact nature of the Quarry bulk wastes that are to be placed on the T'SA pad?

D $-15[$ 13. Have you considered vitrifying the guarry wastes (that is, fusing them into a glassy matrix), or contalnerizing them at the Quarry -- before moving them to the TSA? Have you considered contalnerlining the wastes, for example, in metal containers -.. and then storing the wastes in the containers at the storage site until a final disposal site is found? Would a containerization alternative be more in keeping with the superfund requirement that the cholce of an Interim Remedial Action inay not prejudice the choice of the final disposal 


\section{Response D $\mathrm{m} 11$}

The exlsting characterization data, with respeot to the concentrutlons of radlum Isotopes, are adequate to design approaches for controlling radon releases. A detalled evaluation of radon emissions and potentlal control requirements was prepared in support of the FS. These analyses demonstrate that a soll cap is not needed to reduce the release of radon gas to low levels. An impermeable cover (such as a flexible-membrane liner) will be used to control radon amissions from radlum-contaminated solls and sludges. A flexible membrane liner will reduce radon emissions to levels below the EPA permisslble standard of $20 \mathrm{pCl} / \mathrm{m}^{2}-\mathrm{s}$. Soll sovers are typlcally used when designing disposal cells because long-term integrity is of paramount importance; a soll cap is not needed for thils action given the short duration of the temporary storage perlod. Although Impermeable covers alone are expected to adequately control radon emissions, uncontaminated soll will be avallable nearby as a contingency measure for placement on top of the covers, if needed.

\section{Response D-12}

The average dose rate from external gamma radiation is estlmated to be $0.5 \mathrm{mrem} / \mathrm{h}$ for all phases of this action during which workers will be in close contact with the wastes. Although the maximum dose rate could be as high as 20 to $30 \mathrm{mrem} / \mathrm{h}$ in very locallzed areas of the quarry, the dose rate would generally not be expected to exceed a fow $\mathrm{mrem} / \mathrm{h}$. It is not practical to provide shielding against penetrating gamma radiation by protective clothing. Such clothing would be very heavy and would greatly $1 \mathrm{~m} / \mathrm{t}$ worker effectiveness, resulting in a longer exposure period. Thus, although the dose rate would he somewhat lower, the net effect could be higher worker doses. It should be noted that shlelding against gamma radiation wlll be provided by the excavation equipment, which is constructed of iron and steel. In order to keep worker exposure to penetrating gamma radiation at low levels, areas within the quarry and at the temporary storage area having gamma dose rates in excess of $0.5 \mathrm{mrem} / \mathrm{h}$ will be posted and roped off. Strict work time limitations will be placed on workers entering these posted areas.

Workers in the quarry and temporary storage area who are not enclosed within controlled-air work stations will be provided with masks or other protective equlpment to protect against inhalation of radloactively contaminated dust. Although such masks do not screen out radon gas, they do remove the radioactive decay products (sollds) that constitute the primary hazard associated with radon gas. Effective dust and radon control measures, as well as use of appropriate personnel protective equipment, will be used to protect workers. The work place will be thoroughly monitored for hazardous alrborne contaminants to ensure that worker health and safety is not compromised.

An operational environmental, saf'ety, and health plan is belng prepared that detalls worker, public, and environmental protection procedures; this plan will be completed prior to removal of the bulk wastes from the quarry. In addition, DOE will prepare an emergency response plan prior to inltiating the proposed action. These plans will provide procedures for protecting workers and the general publis under routine and potential emergency situations during the quarry bulk waste remedial action. 


\section{$34 / 35$}

\section{Response D-13}

The permissible levels of radiation exposure for workers is based on limiting tholr health risk to levels that are comparable to the oooupational risks from other Industries that are consldered to be safe. The perm/ssible level $(5 \mathrm{rem} / \mathrm{yr})$ may be reduced as a result of reoent studies Indloating that the risk from exposure to low levels of lonizing radiation is Mlgher than prevlously estimated. The DOE and other foderal agencles are currently examinlng this issue. The radlation closes to workars who would implement this action would be aonsidelably below ourrent limito.

No slgnlflaant changes are expected in DOE concentration 11 mits for radlonuclides in llquid or gaseous effluents as a result of the BEIR V study. The risk faotors presented in the BEIR $V$ roport are consistent with those used by the EPA In developlng revisions to the National Emlssion Standards for Hazardous Alr Pollutants under Section 112 of the Clean Air Act for radionuclides and by the NRC in developing revisions to 10 CFR 20 for permissible levels of radionuolldes in air and water in controlled and uncontrolled areas. The DOE standards are consistent with those developed by the EPA and NRC.

A major element of DOE's radiation protection program for occupational and public exposures is the ALARA concept. Under the ALARA process, all exposures to radiation and all releases of radloactivity to the environment must be reduced to levels that are as low as reasonably achlevable. The DOE is committed to this approach. The proposed action would not be impacted even if more stringent standards were in effect because the predicted levels of radiation exposure to workers and the publla are well below applicable standards.

\section{Response D-14}

Sufficlent data are avallable regarding the concentrations of radioactive contaminants in the quarry bulk wastes based on the history of disposal activities and the results of previous characterization studies, as presented in the RI. However, detalled waste characterization to evaluate treatment options cannot be performed without removing the wastes from the quarry. Because the exact quantity or physical characteristics of the bulk wastes are not known, conservative assumptions were used to estimate the risks to students and staff at Franols Howell High School. The actual risks will llkely be lower than those presented in the FS.

Contamination will not affect students, faculty, or staff at the high school because work at the temporary storage area will stop and exposed areas will be covered if elevated concentrations of radioactive contaminants are detected at the high school. Work will not resume at the temporary storage area untll the cause of the release is identified and corrective actions are implemented.

\section{Response D-15}

See page 37. 
D-15 [olution - - thati is, may not blas the deolulon-making prodesta?

D 16 [14. What are your plars, in detall, cox excavating and segregating the Quarry waste? In partioular, what preoautions are to be implemented to mitigate the potentilal for axploalong and/or ohemlad reactiones Both thortum and urandum and ohomianl dompounds of thorlum and uranlum are pyrophoric and may ignite spontanoously upon contact with air. Some urantum and chemlad forme of urandum may readt violentiy when in contaot with water 1t ts proposed in the faaslolilty study that water: sprays wili be used for dust supprassion, but this potential dangar is not addressed. alven that the nitroaromatios are oxplosive/elamabla materdala, the presencie of pyrophordas and strong oxladzers would areate a greater potential hazard than has been presented in the foasibility study. These problems should be identifled, a comprehenstve avaluation of the potentlal hazards should be provided, and dotalis on methods that: can be implemented to minimize these hazards should be given in the foasiblitty study. It lo not at all clear from the information

D-17 presented in the remeddal investigation, risk evaluation, or feasibility study reports that the potentilal riaks asgoolated with the proposed excavation and storage of quarry waste have boen ldentifled, ovaluated, and quantifled. The proposed alternatives have not been thoroughly evaluated with regard to the hazards and riaks associated with the excavation and storage alternative. Methods of stabilizing the waste in place with subsequent removal and storage at the TSA should be evaluatid in more detali so that a more objective somparison of riak and cost fak the alternatives can be made.

D-18 15. The proposed plan for the Quarry bulk waste removal and storage does not provide for any backup proteotion in the event of fallure of the plastio cover of the unintencional removal of the cover during an unplanned incldent, such as a tornado or atorm with high winds. Could a monitoring system possibly provide suffolent warning of a large atrborne release to be able to evacuate the school and nearby residences? Do you propose to provide resplrators to all sahool ohlidren, teachers, and nearby resldents? what other contingenoy measures are being considered to prevent unintentional alrborne releases if the prinary protection method (that 1s, the weighted plastic cover) fails? 


\section{Response D-" 15}

Vitrlfleation of the quarry bulk wastes was ruled out as a troat'nent optlon for saveral reasons, orie of whloh is the blasing of elnal treatrinent and disposal optlons for these materlals. In addition, the nature and plaoement of materlals lin the quarry ls not conducive to in-sltu vitrifloatlon. As ourrently planned, the bulk wastes wlll be loaded Into large contalners and transported by truck along a dedloated haul road to the temporary storage alea. There, the oontalners will be unloaded and the wastos placod dlecetly Into controlled atorage. Storage of the bulk wastes in contalnors at the temporary storage area would not permit efflolent oharacterlation. However, nolther bulk storage nor contalnerized storage will blas the seleotion of the flnal dlsposal alternative for these wastes.

\section{Response D-16}

Detalled plans for excavating and segregating the wastes will be developed and presented in design documents. The level of detall necessary to determine the engineering feaslbillty of this aotion was presented in the preliminary engineerine report supporting the FS. Canceptual and flnal design documents that will be developed will focus on the physloal aspects of waste removal such as equipment, operations, materlal handling, and cost. Plarining related to deallng safely with the varlous types of contaminants and hazards encountered - such as environmental monltoring plans, health and safety analyses, contingenoy plans, and worker protection plans -.. will be desoribed In the operational environmental, safety, and health plan. The results of these two planning efforts will be Integrated into the suboontraot bld clocument to ensure that the subcontractor has the equipment ard expertise to respond to oonditons likely to be encountered cluring thls action.

No evidenoe exlsts to suggest that conoentrated forms of thorlum or uranlum were deposited in the quarry. Such materlals would have economlo value, and it is unllkely that they would have been intentlonally disoarded. Firthermore, the quarry wastes have been exposed to water Inflitration for more than 20 years, whioh would contribute to corrosion of the original waste containers and oxldation of the waste materlals. There is no basis to suspeot that reactivity hazards assoclated with uranlum and thorlum compounds will be encountered during the exoavation process.

The proposed aotion was reviewed by Heroules Incorporated, a company with extenslve expertlse in dealing with explosives. The results of this review are provicled in the report entltled Explosive Hazard Review for the Weldon Spring Site Remedial Action Project Quarry Excavation, whlch was completed In July 1890. This review conolucled that potential explosion hazards could be effeotively mitigated by personnel training and operational controls. Mitigative measures will be used to ensure that the proposed action is implemented safely, e.f., materlals wlll be sprayed with water to minimize the ohance of Ignition. Recommendations provided in the review will be Incorporated Into approprlate environmental, safety, and health plans prior to Initiation of the proposad action. 


\section{Response D-17}

'The level of detall provldad in the RI/Fs doouments is conglstent with that requlred by EPA for actlons of thls type. Detalled enginearing for this action oannot be InItlated untll the reoord of declaton has been Issued. 'The analyses presented In the RI/FS and supportlig documents clearly Indloates that there is a need for timely response and that thls action oan be performed safely and In oompllanoe with all pertinent standards and regulations. Additional evaluation of the various alternatives is not warranted.

\section{Resporise D-18}

The DOE will prepare an emergenoy response plan prich to Initlation of the proposed aotion. Thls plan will detall steps that will be taken in the event of an unplarined Inoldent guon as a tornado strlke or a storm with high winds that oauses massive darnage to the cover. In developing this plan, DOE will Involve the Franois Howell Sohool Dlstriot and local of folals who would require notlfleation or coordination In the event of an emergenoy. The DOE will not Inltlate thls actlon untll an emergency response plan has been developed to ensure the health and sufety of nearby individuals. It will not be necessary to provide resplrators to members of the general publio to ensure thelr safety under any oredible conditions. Contingenoy measures to cleal with unintentional airborne releases will be Included in the operational environmental, safety, ard health plan ourrently belng developed. 


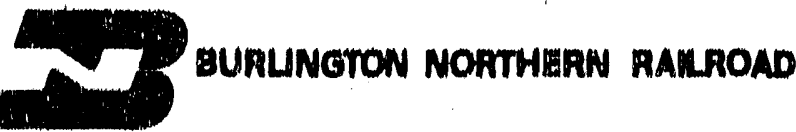

April 9, 1990

Mr. Stephen H. McCracken

Project Manager

United States Department of Energy

Weldon Spring Site Remedial Action Project

7295 Highway 94 South

St Charles, No 63303

Dear Mr. McCracken :

This is in response to the Weldon Spring Remedlal Action Project whereas written comment be postmarked on or before April 9, 1990 to become part of the Administrative fiecord and will be considered in the Record of Decision.

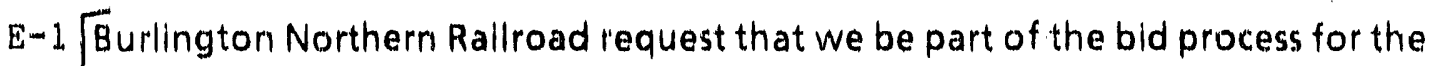
transporation portion on hazardous or contarnined commodity on movement from St Charles area to Richland, Wa or alternate destinations.

If we can assist you in any way, please do not hestlate to give us a call at numbers shown on enclosed business cards.

Sincerely,

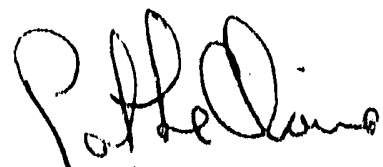

Pdtrick S LeClaire

Market Manager

Enivronmental logistics 


\section{Response $\mathrm{E}-1$}

The proposed aotion involves truck transportation of the bulk wastes from the quarry to the chemical plant area along a dedloated haul road. The one-way distance is about $5.4 \mathrm{~km}(3.4 \mathrm{ml})$. Thls action does not entall movement of any materlals to Rlchland, Washington, or any other off-site destination.

The DOE appreciates the Interest expressed by Burlington Northern Rallroad on this project. Burlington Northern Rallroad will be inclucled in the bid process for any action that entalls the bulk transportation of large volumes of contaminated materlals to off-site areas for treatment and disposal. 


\section{Letter $\mathrm{F}$}

Steven H. MeCrachen, Froject Manager

$U_{n}$ S. Department of Energy

Weldon Spring Site Femedial Action Froject Site

7295 Highway 94 south

St. Charles, MO 6380

Dear steve,

I an sending herewith my written comments to you in response to the froposed plan for the managenent of the weldon spring duarry bull: wastes (DOE/OF/215Ag-105i). This response is being sent to you within the extenaion of comment. period obtained by Meredith boll mei er through your offics and with the consent of Eob Morby, chjef, Guperfund Eranch, L. S. EF'A Fiegion VII.

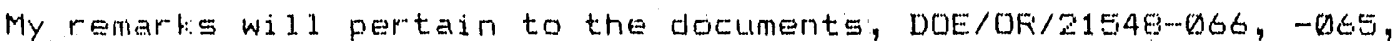
-1 . 4, and -106 . These reports seem to be technically sound and well written with ideas and facts obtained from extersive studies of the available date for the weldon spring site. I am pleased that the actual logistics of the waste rrmoval was considered in the context of the effects on the Francis Howell school children as well as other bioloigical forms. My overall impression is that of a positive one for the project and I would like to commend the DoE personmel for the soundriess of the proposal"

E-1 However, I am not convinced that alternative 5 is any better than alternative 6 as proposed in Table 1 of document -105 . Higher monitoring costs and inflation are cited as the main drawbacks of delayed action. As reported in the public hearing on March 29,1990 expecliated action is expected to cost $11 \mathrm{milion}$. According to my calculations, if $F Q D$ can be reached by 1994 (a reasonable estimate even by DOE and according to OTA-ITE-362), and allowing for a moderate inflation in moving costs the Guarry wastes could be moved after fion, at a savings of substantiaj tak dollars. In addition, students, public, and other living forms will not be exposed to radioactive dustse twice. Therfore, it seems prudent to wait and move the bull: wastes at the tame of the fiod for the site.

F-2 [I am also perplexed at the assumption made as a basic guiding principle for the proposal (-104) that somehow by removing the radioative waste from the quarry and restoring it in another temporary sjte which is about $6.4 \mathrm{~km}$ from the quarry will reduce the radioactive enission of Fadon. How is this reduction in radiactivjty going to be achi eved? 


\section{Response F-1}

Alternative 5 is preferred over Alternative 6 because Alternative 5 is responsive to ongoing, uncontrolled releases to the environment in the quarry area and is consistent with current plans for remediating the entire Weldon Spring site. Alternative 6 would postpone the attainment of remedial action objectives at the quarry (e.g., removing the source of contamination and initiating necessary characterization activities in the quarry area). The preferred alternative can be implemented in a manner that will not endanger students and staff at Francis Howell High School or any other individuals in this area. The extensive monitoring program currently in place will be expanded to ensure the health and safety of nearby residents and the environment as a result of this action.

The DOE is currentiy preparing an RI/FS-EIS to evaluate alternatives for the permanent disposal of all wastes generated by remediating the Weldon Spring site. Although the RI/FS-EIS will be available for public review and comment in 1991, the length of time to implement permanent disposal options will take several more years. Delaying the proposed removal of the bulk wastes would result in continued, uncontrolled releases of contaminants to the environment in the quarry area. The proposed action is being taken at this time to respond to this release.

Some additional cost and environmental impacts will be associated with placing the wastes in temporary storage, but most of the components associated with this action will be required whether the action is taken now or in the future. The wastes must be removed and characterized to evaluate various treatment options prior to final disposal. The incremental cost is a good expenditure of funds based on the considerable benefits associated with expediting the action, i.e., the proposed action will further protect human health and the environment and support overall waste management decisions for the project. These (and other) reasons for conducting the proposed action are discussed in greater detail in the FS. This action will be taken in a manner that will minimize iinpacts to students, the general public, and nearby wildlife.

\section{Response F-2}

The emissions of radon gas from the bulk wastes will be reduced by compacting the radium-contaminated soils and covering them with a liner that is very effective at reducing radon gas releases. Because radon isotopes have short half-lives ( 3.8 days for radon-222 and 55 seconds for radon-220), control of radon releases is achieved by increasing the length of time it takes for radon gas to reach the atmosphere. This permits a significant amount of radioactive decay to occur (i.e., to solids). Compacting the materials reduces the pore space through which radon gas can diffuse, and using a heavy cover (such as a flexible-membrane liner) greatly reduces radon gas migration out of the soil. These two measures allow for a significant amount of radioactive decay to occur prior to release to the atmosphere. 
F-3 TIndesed, the remarbs made on p so of dotument ‥bes suggest that the quantities of radioactive inaterial in the quarmy are high and therefore, war ant a beter contenment of the wastes rather than move the material twice, one for temporary stomege and a second time for

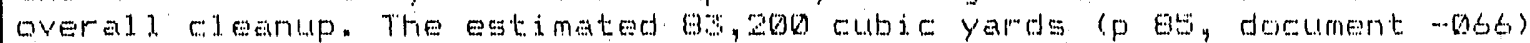
was later increased to 95 , obo cubic yar cls of radiological waste becuase of discrepancoss in measurements ( $p 75$, document -066$)$. Bewase of suen uncertajnities in estimating the totad. waste (because of the rature of the waste) I cannot suggest the removal of unlinown guantities and expote the public to even greater riskis.

F-4 [DOE may not have been able to characterize the nature of the radionctive waste, since the aval able recorde could have been incomplete and friccurate (see attachments 1,2). I mate thic assumption because there was no reference as to the maturg of the waste originated

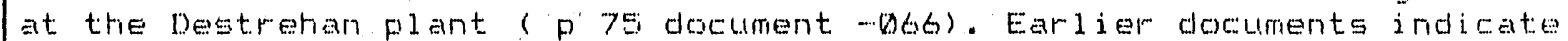
that. Belgian Congo ore was processed at this plant and that this ore was of higher grade. Therefore, much more ekensive characterization of the radiological. waste at the quarry seens to be needed before the final. removal. for cleariup.

F-5 The availatle documents seem to indicate that adternative 5 is the preferred choice for DOE, and if the decision has already been made to move the quarry waste, then I would 1 ilie to make the following suggestions.

F-6 [1. Eecause of the wind directions the waste should be hauled in off-school times and in the night during winter and early spring ( $P$ q dorument $-\Delta 65)$.

F-7 [2. Further exhaustive investigations for TSA should be carried out. The proposed location seems to overlap with potential nitroaromatic: Lource areas (see attachments 344 ).

F-8 [3. A careful analysis of advanteges of pre-sorting the wastes prior to hauling as opposed to the DOE preferred after-sorting procedure should be carried out with the idea of minimizing the potentied rist:s to Living orgarisms and ecology.

F-9 $[4$. The design of the rsa should be suitable for not only storing radiological wastes but also for chemical. wastes including golvents. Is the 4 inch thich concrete layer sufficient to stop the leatige of industrial solvents? 


\section{Response F-3}

One of the reasons for expediting this action is to place the wastes into controlled storage to reduce releases to the environment. The fractured limestone quarry is not an acceptable location for storage of these materials. The volume of material in the quarry is estimated to be about $73,000 \mathrm{~m}^{3}\left(95,000 \mathrm{yd}^{3}\right)$. This volume will likely increase due to swelling as the wastes are excavated. The temporary storage area will be designed to store $110,000 \mathrm{~m}^{3}\left(140,000 \mathrm{yd}^{3}\right)$ of contaminated materials associated with this action. The exact volume of materlals will be known only upon completion of the action. Contingencies will be bullt into engineering design to ensure sufficlent storage space.

\section{Response F-4}

Although Belgian Congo ore was processed at the Destrehan Street Plant, it is highly unlikely that significant quantities of the wastes from processing this ore were deposited in the quarry. The residuer from frocessing this ore are located at two other DOE facilities (i.e., at the Feed Materials Production Center near Fernald, Ohio, and at the Niagara Falls Storage Site near Lewiston, New York). These residues do contain high concentrations of radium-226 because the Belgian Congo material was a very high-grade ore. Any processing materials from the Belgian Congo ore that were deposited in the quarry would be dispersed in the bulk wastes, greatly reducing their concentrations. The radioactive constituents in the quarry bulk wastes are well known based on previous characterization activities; this information is summarized in the RI. Detailed characterization to evaluate treatment options cannot be performed without removing the wastes, due to their highly heterogeneous nature. Additional characterization to support removal of the bulk wastes is not warranted.

\section{Response F-5}

The DOE has not yet reached a decision on implementing Alternative 5 . However, this alternative is preferred by DOE. A joint EPA/DOE record of decision will be issued this year documenting which alternative will be implemented.

\section{Response F-6}

The DOE will consult with the Francis Howell School District to ensure the safety of students and staff during all phases of the proposed action, including transportation activities between the quarry and chemical plant area. However, there is no need to restrict transportation activities due to wind direction. Transporting the bulk wastes to the chemical plant area and placing them into temporary storage can be much more safely performed during daylight hours. Transporting the wastes would be much more hazardous at night than during the day because of reduced visibility. The most significant risk to the general public from implementing this action is that associated with transportation accidents, which is the primary reason for constructing and using a dedicated haul road. An extensive environmental monitoring program will be utilized to ensure the health and safety of workers and the general public. 


\section{$44+7$}

\section{Response F-7}

The potential nitroaromatic source area identified in Attachment 4 is located off-site, just west of the proposed temporary storage area. The location of the proposed temporary storage area has been thoroughly characterized for nitroaromatics; the results of this characterization are summarized in Section 9.7 of the FS and described in detail in the cited references.

\section{Response P-8}

On the basis of continuing engineering studies, DOE has reviewed its conceptual plans for removing the bulk wastes and has developed a strategy that will allow the wastes to be sorted at the quarry. Some sorting may still be required at the temporary storage area. This limited sorting can be safely performed at the chemical plant area with minimal risk to living organisms and the environment.

\section{Response F-9}

The temporary storage area will be designed to safely store all of the quarry bulk wastes. As currently envisioned, the foundation of the temporary storage area would consist of a $10-\mathrm{cm}(4-\mathrm{in}$.) thick asphalt-concrete surface underlain by an aggregate base and a 30-cm (12-in.) thick layer of recompacted clay. The asphalt-concrete pad will function primarily as a working surface for the heavy equipment and as protection for the clay liner. The low-permeability clay layer will function to prevent the migration of solvents at the low concentrations present in the wastes. In addition, a major component of the temporary storage area will be a leachate collection system that will collect any leachate that may occur during the temporary storage period. This design will adequately contain any leaks of industrial solvents that may occur during the relatively short temporary storage period (i.e., three to six years)。 


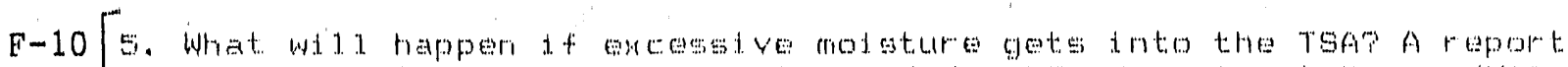

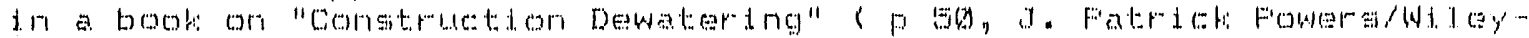

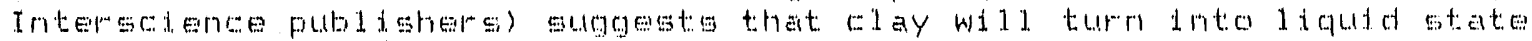

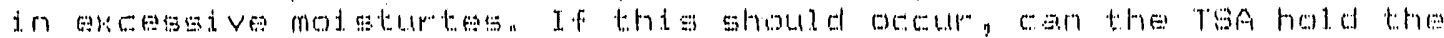

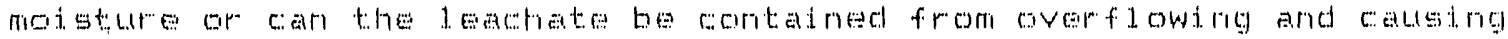

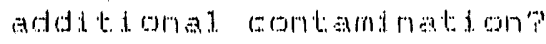

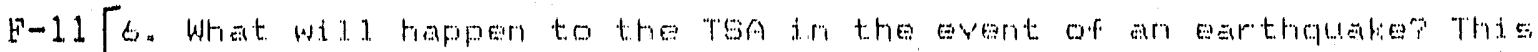

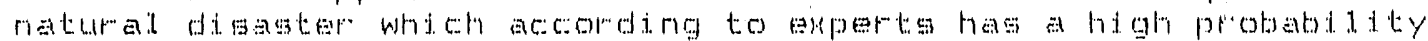

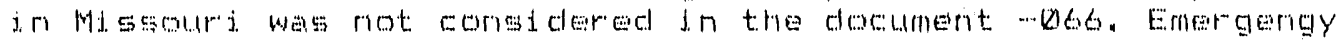
procedures and protocol should be developed for the and other natumat

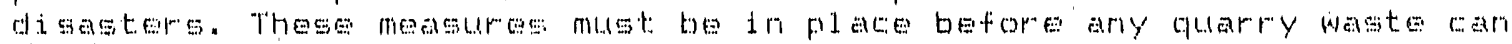
b) moved (ses at.techments 5,6$)$.

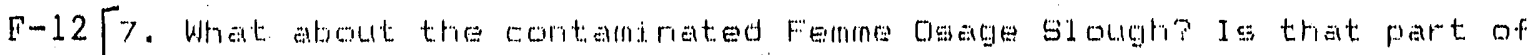
ancot:her" renedidi action?

F-13[8. Fears arising out of past. DOE's actions and partial citearips and

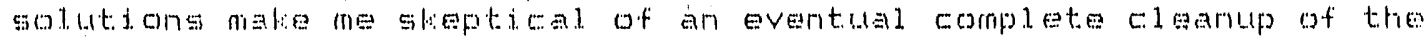
Weldon spring site. Therefore I hesitite to accept the good intentions

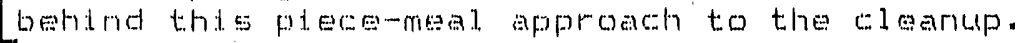

F-14[In conclusion, $\mathrm{d}$ am not convinced that the DoE has yet wecogntad the

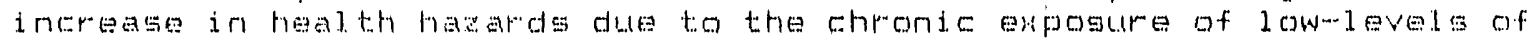
radigactivity. This is somewhat gurprising in view of the slowly

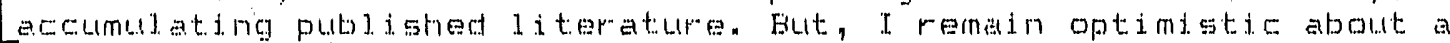
suteessful remedial action of the Weldon spring site. I wellome the chance to forward my comments to this project and appreci ate your and DOE's efforts in this regard.

Ginceredy Your $=$ ?

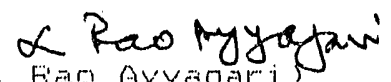

(.L.. Fiano Ayyagarj.j.

14 Fied Oal:

St. Feters, MO 0397 


\section{Response $\mathrm{F}-10$}

The temporary storage area will be designed to ensure its structural stabllity. Provisions to prevent excessive amounts of molsture from reaching the recompacted clay will be incorporated into the design. Storm-water runoff and leachate from within the temporary storage area will drain by ditches and swales to collection ponds located within the temporary storage area. Thls water will be treated prlor to discharge in the water treatment plant to be constructed at the chemlcal plant area. Surface water runon to the temporary storage area will be controlled by diversion ditches surrounding the area. These measures to control surface water in the immediate vicinity of the temporary storage area will eliminate the possibility of damage to the clay foundation due to excessive moisture.

\section{Response F-11}

According to the Building Officials and Code Administrators (BOCA) National Building Code, seismic zones are numbered from 0 to 4 , with Zone 4 being highest in terms of earthquake risk. Based on this code, the temporary storage area is located in Seismle Zone 2. If a major earthquake were to occur during the active waste storage period, the primary concerns would be cracking of the asphali-concrete working pad and/or slide fallures on the steeper slopes of the plles. It should be noted, however, that an earthquake would not produce forces that could result in the widespread dispersal of stored materials. The temporary storage area would be repaired, if needed, following the earthquake.

The DOE will prepare an emergency response plan prior to initiating the proposed action. In developing this plan, DOE will involve the Francis Howell School District and local officials who would require notification and coordination in the event of an emergency. The DOE will not initiate this action until an emergency response plan has been developed to ensure the health and safety of nearby individuals under credible conditions, including the effects of earthquakes and other severe natural phenomena.

\section{Response F-12}

A decision on the need to remediate Femme Osage Slough will be included in the follow-on decision-making process to be conducted for the quarry area following removal of the bulk wastes. A decision cannot be reached at this time because Femme Osage Slough appears to be hydraulically connected to the contaminated local groundwater systenı.

\section{Response F-13}

The history of environmental compliance and protection at DOE facilities has not been good. However, this is currently DOE's highest priority. The DOE looks forward to your careful review of actions at the Weldon Spring site to allay your fears. In addition, because the site is on the NPL, EPA Region VII is responsible for ensuring the adequacy of the cleanup.' Representatives from EPA Region VII have made it very clear that they will not delist the site from the NPL until they are satisfied that all required remedial actions have been completed. 


\section{Response $\mathrm{F}-14$}

The DOE does Indeed reoognlze that the risk from exposure to low levels of lonizing radiation may be higher than had prevlously been estlmated. The revently issued BEIR V study presents a detalled description of current data on the health risk of exposure to low levels of lonizing radiation. 'This study estimates that the health risk is about three times greater than estimated in the prevlously issued BEIR III report. The DOE takes this information seriously. However, it should be noted that the data used to reach these conclusions have limitations, as noted in the BEIR V study. Assessment of the carcinogenic risks that may be assoclated with low doses of radiation were extrapolated from effects observed at doses larger than 10 rem delivered over a short period of time. In addition, it was necessary to use assumptions about the relevant dose-effect relationships and the underlying mechanisms of carcinogenesis.

Health hazards assoclated with chronic exposure to low lovels of lonizing radiation have been studied in areas such as those having high levels of background radiation, areas receiving fallout from nuclear weapons testing, and areas near nuclear installations; the data from these studies do not indleate an elevated level of cancer risk. Hence, it is still not possible to draw definitive conclusions of the cancer risks associated with chronic exposure to low levels of ionizing radiation.

A major element of DOE's radiation protection program is the ALARA concept. Under the ALARA process, all exposures to radiation and all release of radioactivity to the environment must be reduced to levels that are as low as reasonably achievable. This ensures minimizing radiation doses and resultant health risks. 


\section{WELDON SPRING GUARRY DI SPOSALTHISTORY}

$1942 \cdot 1945$ NITROAROMATICS AND RESIDUES

? QTY

1948

NITROAROMATICS AND RESIDUES

90 TONS

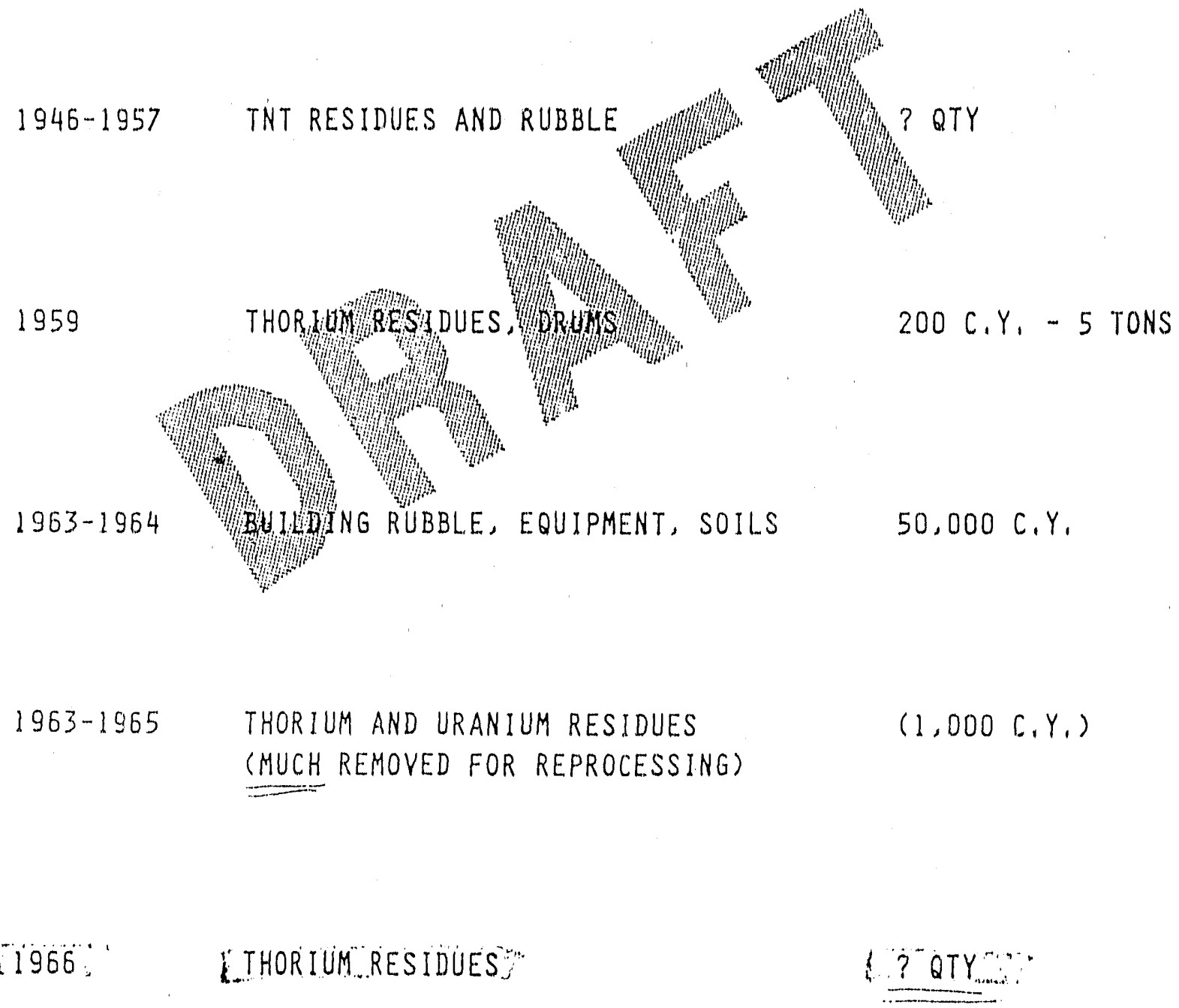

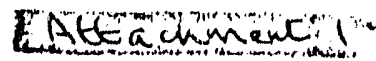




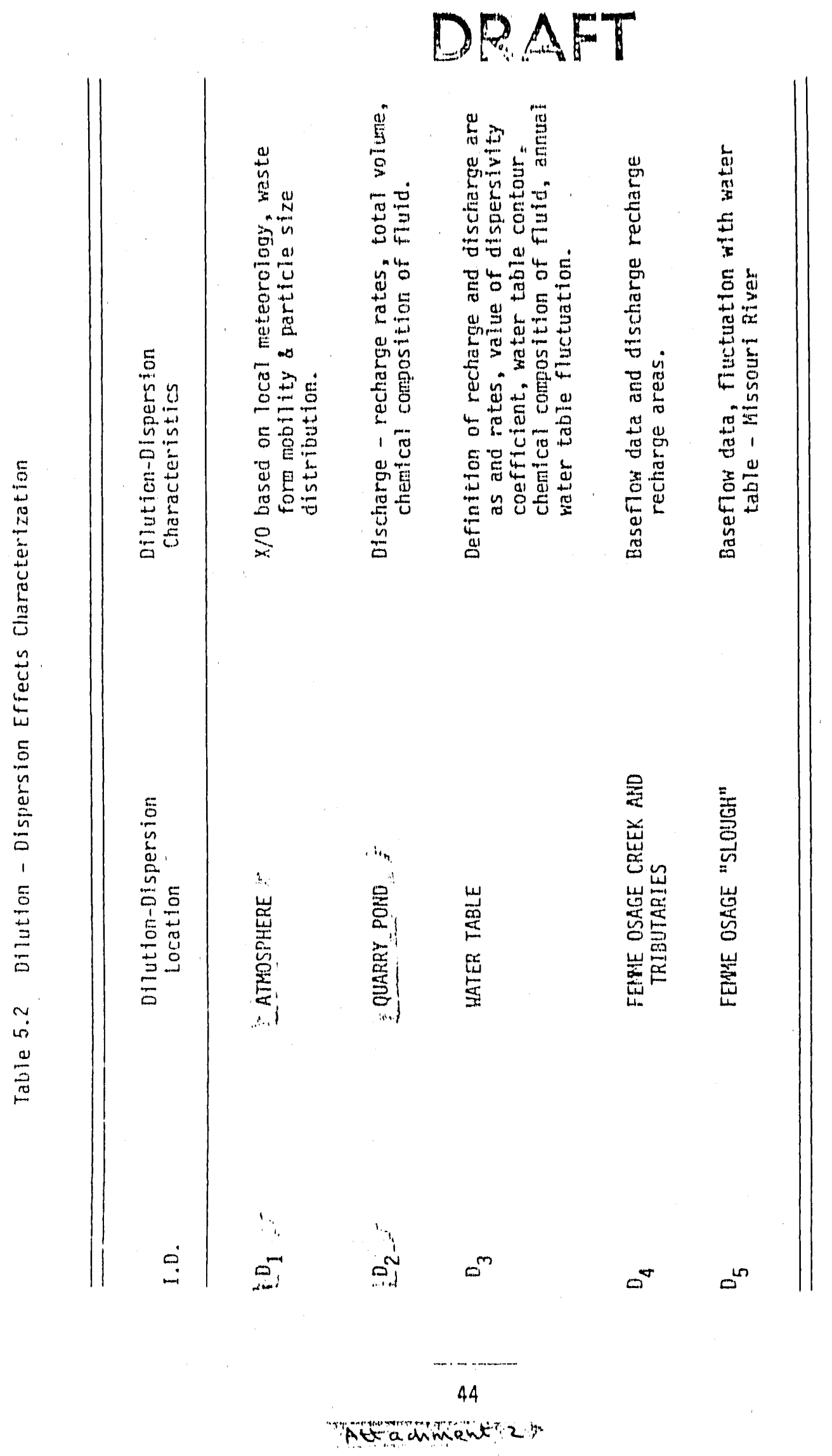


AGISNDA TOR DTSCUSSTON OF IHLE TECWNTCAL,

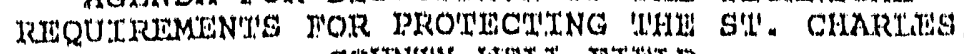

COUN'I'X WEIIL FTLLD

APRTT 27, 1988

Introduation

1. Historioal Raviaw

2. Current Monitoring status - what is the current pleture of contaminant extent and migration using clata sources from DOE, DNR and $s t$. chariles County.

a. Sourdes - Slough \& Quarry

b. Extent of migration

c. Monttoring welis in place

3. Evaluation of Mondtoring Efforta

a. Adeguacy of extsting well retwork for well fideld protection

- Hydrologio effect of Wells 2, 3, and 9

- Effect of glough as a source

- Best indicator parameter for monltoring

- New production wells on IIne

b. Redundancy or overlap of monitoring efforts

c. Future Characterization Activities

- Bedrock/alluvidum interface

- Groundwater to west and north of quarry

- Flow patterns and migration pathways

- Treatment of slough water

- other

4. Discussion

5. Issues and Topies for Future Meetings

Source for attachinents 1, 2 . 


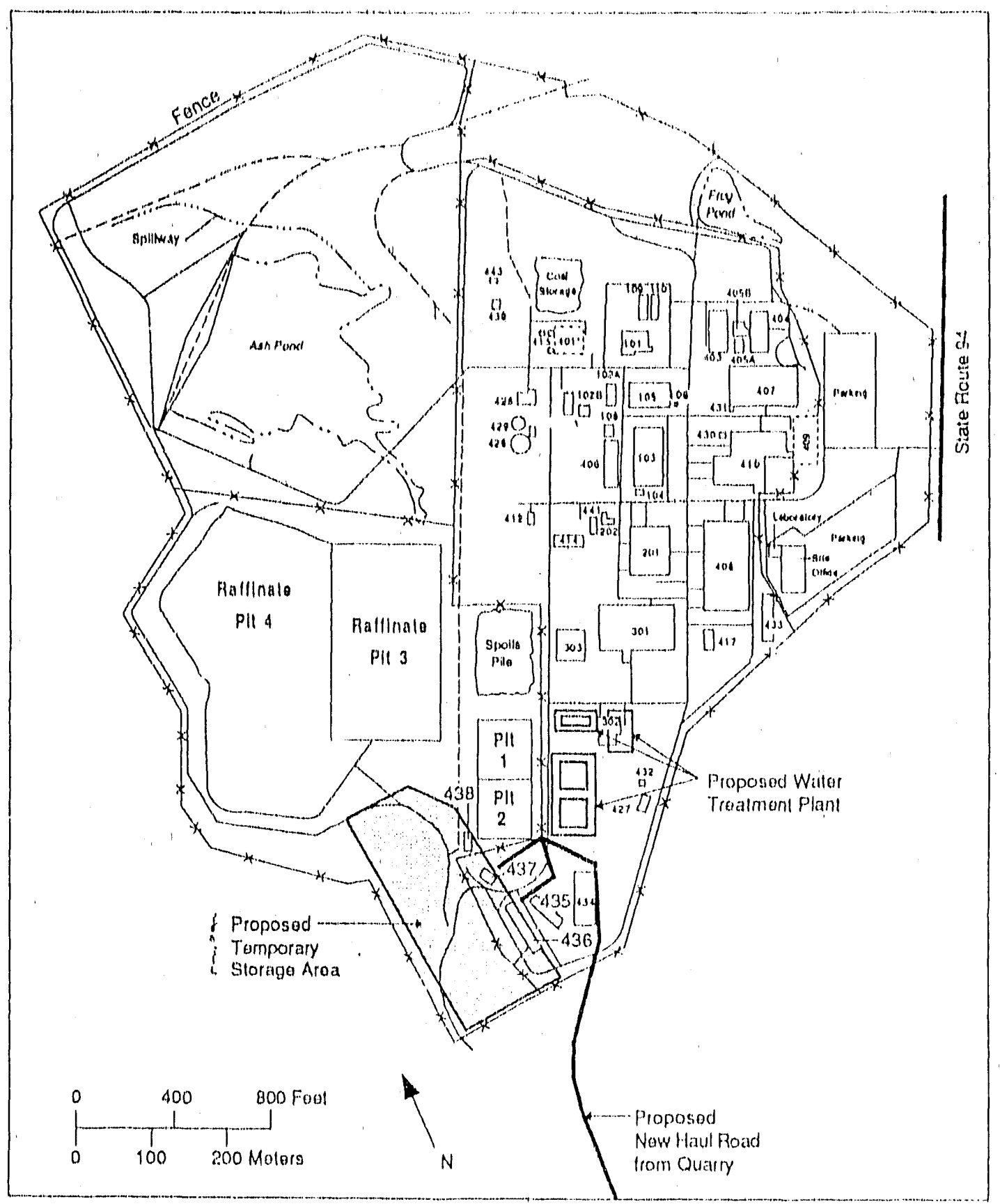

FIGURE 8.8 Proposed Location of the TSA (Source: Modified from MK-Ferguson Company and Jucobs Englneering Group 19906)

ittadnucht 3 


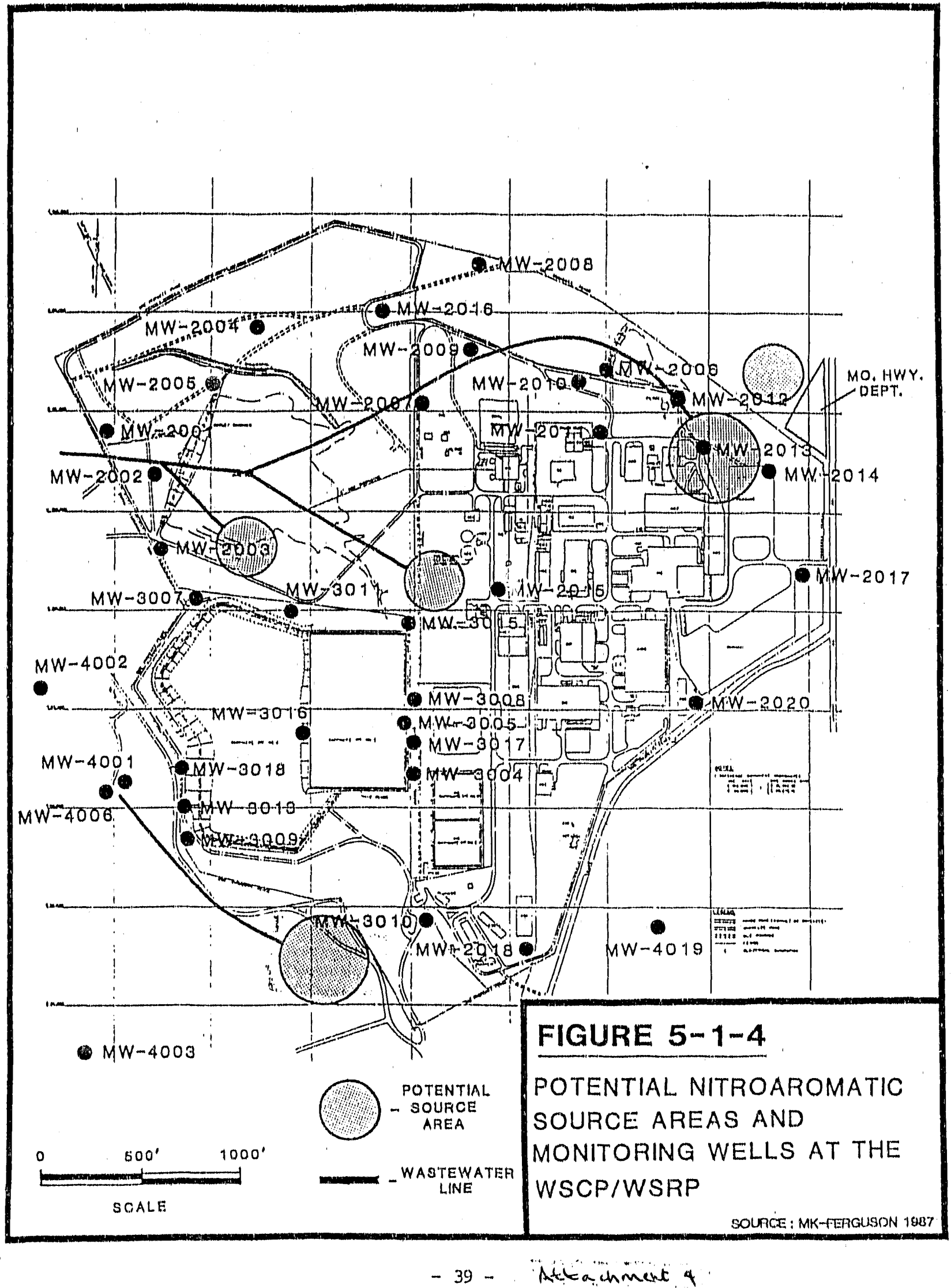


DOE/OR/21548-003

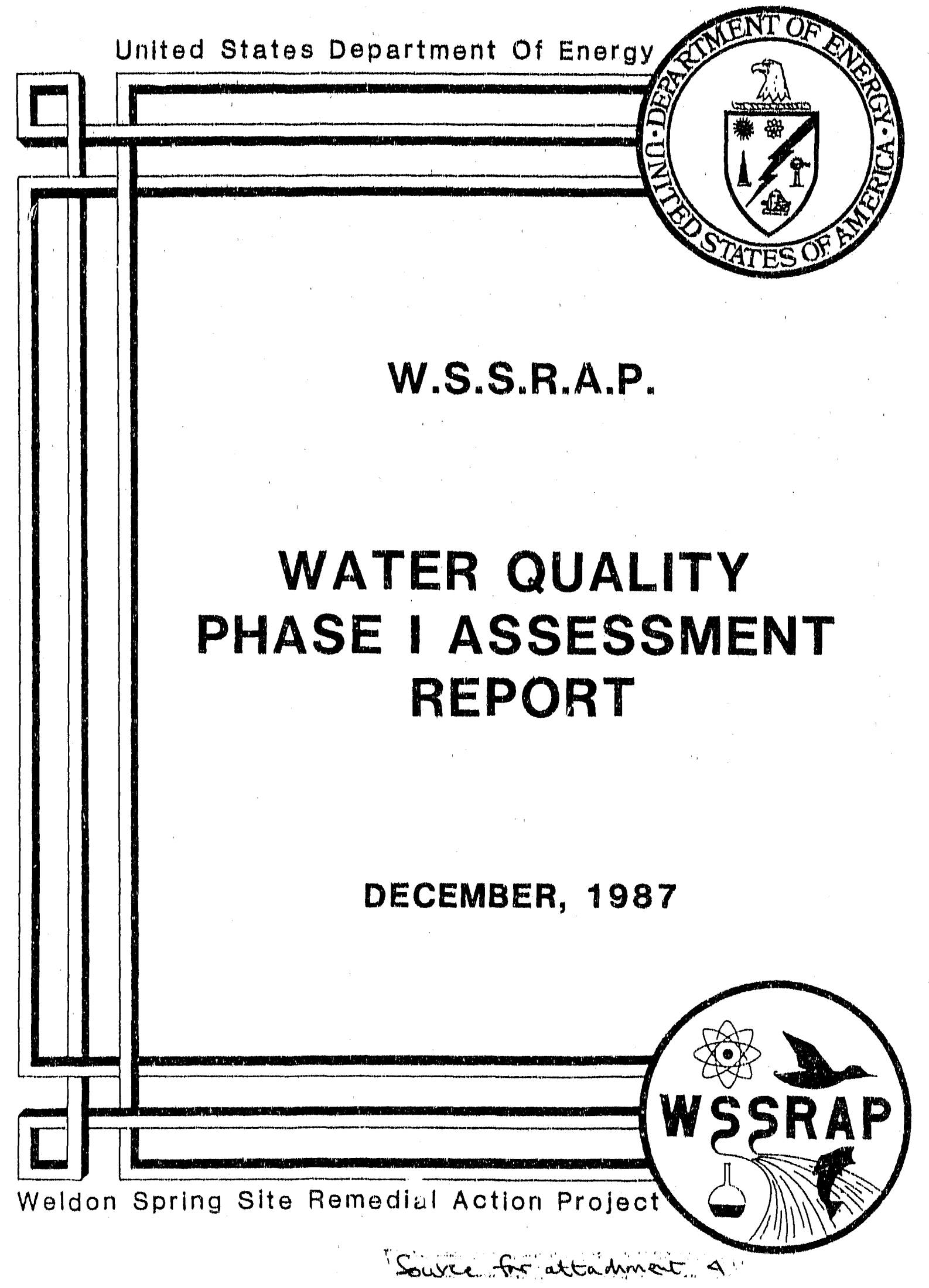


DKAFT

Table 5.3. Effect of Abnormal Events on Control Barriers and Dilution

\begin{tabular}{|c|c|c|}
\hline \multirow[b]{2}{*}{ Event } & \multicolumn{2}{|c|}{ Adverse Effect on } \\
\hline & Control Barrier & Dilution-Dispersion \\
\hline Earttiquake & 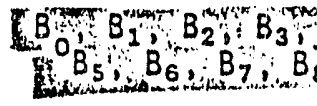 & \\
\hline Lightning, Meteorite & Bo, $B_{1}, B_{2}, B_{3}$ & \\
\hline Flood/Heavy Rain & 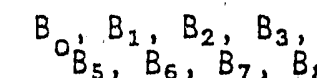 & \\
\hline Drought & $B_{0}, B_{1}, B_{2}, B_{3}$, & $D_{2}, D_{3}, D_{4}, D_{5}, D_{6}$ \\
\hline Tornado & $B_{0}, B_{1}, B_{2}, B_{3}$ & $D_{1}$ \\
\hline Vandalism/Sabotage & $B_{0}, B_{1}, B_{2}, B_{3}$ & \\
\hline
\end{tabular}




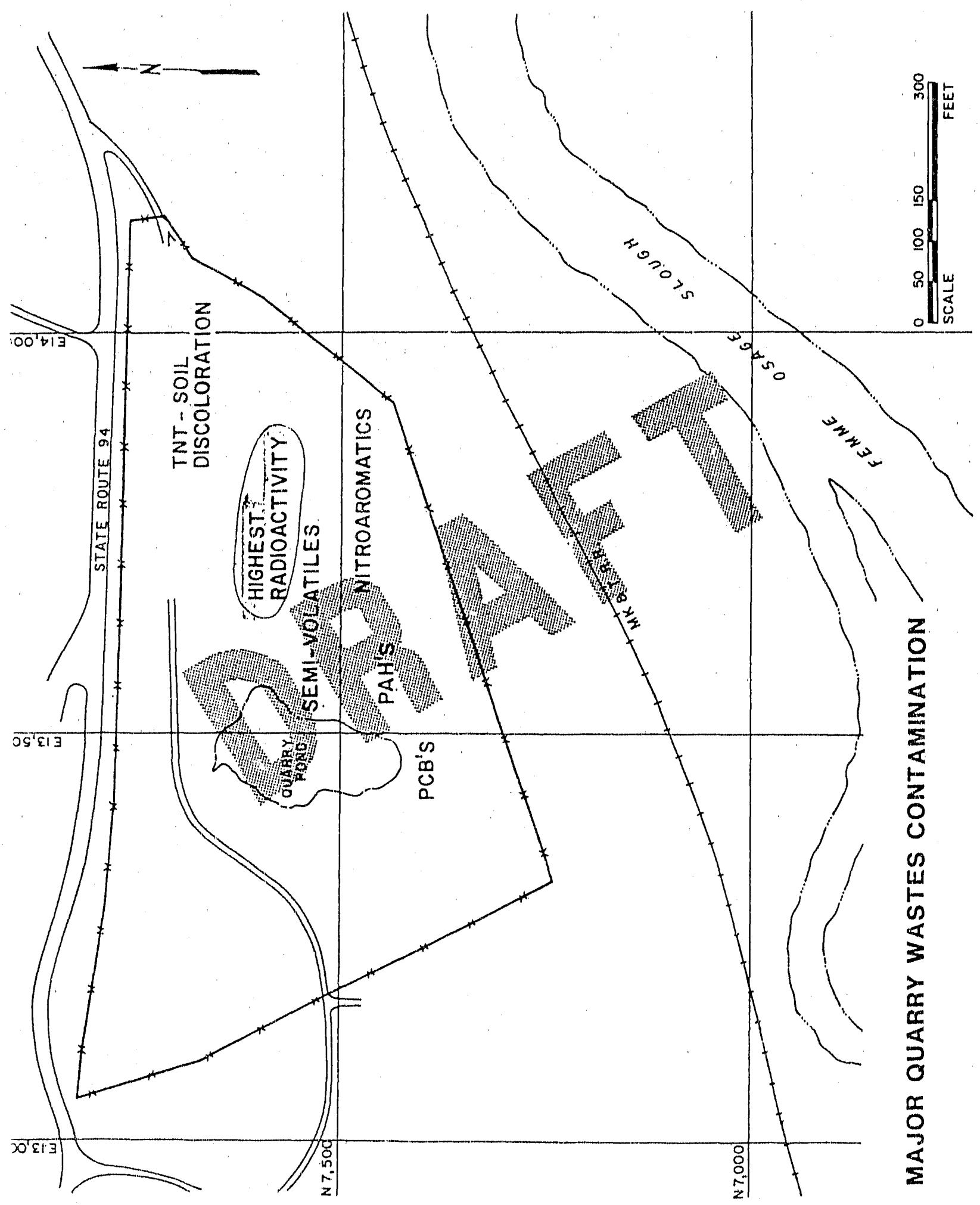

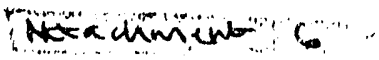


SAI-OR-79-135-0I

\section{DRAFT}

PRELIMINARY RISK ASSESSMENT OF THE WELDON SPRING ROCK QUARRY

September 1979

Science Applications, Inc.

Dak Ridge, Tennessee 37830

\section{Prepared for}

Oak Ridge National Laboratory Oak Ridge, Tennessee 37830

Under Letter Release 84Y1] of Subcontract $848-13861 C$

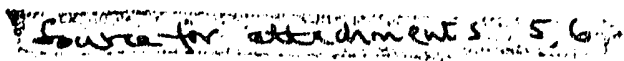




\section{Leter $\mathrm{C}$}

This hand-written letter was typed verbatim for clarity of presentation. The original letter is available for inspection at the DOE office at the Weldon Spring site.

April 13, 1990

Mr. Steve McCracken, Project Manager

U.S. Department of Energy

Weldon Spring Site Remedial Action Project Office

7295 Highway 94 South

St. Charles, MO 63303

Dear Mr. McCracken:

I would like to take this opportunity to express some of my concerns regarding the RI/FS and the proposed plan for the quarry bulk waste remedial action. They are listed as follows:

1. Why bring the wastes to the plant site before sorting? Wouldn't it be far better to sort and contuinerize at the quarry site before transporting to the temporary storage site at the plant.

3. The wastes should be hauled at night or when school is not in session in order to further safeguard the students and faculty.

4. The sorting pad should be completely enclosed and air-filtered to prevent movement of air-borne contaminates during separation/ containment. Also, if possible, the entire quarry area should be enclosed during cleanup procedures.

5. There should be a solid $12 \mathrm{ft}$. high fence (not merely chain-link) to cut down on air-borne particles escaping and to prevent thrill-seekers from easy access to the temporary storage site and sorting pad.

6. In the Feasibility Study manual on page 7-1 under compliance with ARARs, what are the applicable ARARs being considered? Is the waiver of compliance a loophole so that proper procedures do not have to be adhered to? 


\section{Response G-1}

On the basis of continuing engineering studies, DOE has revised its conceptual plans for removing the bulk wastes and has developed a strategy that will allow for the wastes to be sorted at the quarry. In this revised approach, the wastes will be sorted as they are being excavated and will be loaded into containers such as large steel boxes. These containers will be transferred to trucks for transport to the chemical plant area where they will be unloaded and the wastes placed directly into controlled storage. The empty containers will be returned to the quarry for reuse. This approach will provide an efficient means for conducting this proposed action with increased operational flexibility.

\section{Response G-2}

Although Belgian Congo ore was processed at the Destrehan Street Plant, it is highly unlikely that significant quantities of wastes from processing this ore were deposited in the quarry. The residues from processing this ore are located at two other DOE facilities (i.e., at the Feed Materials Production Center near Fernald, Ohio, and at the Niagara Falls Storage Site near Lewiston, New York). These residues do contain high concentrations of radium-226 because the Belgian Congo material was very high-grade ore. Any processing materials from the Belgian Congo ore that were deposited in the quarry would be dispersed in the bulk wastes, greatly reducing their concentrations.

\section{Response G-3}

The DOE will consult with the Francis Howell School District to ensure the safety of students and staff during all phases of this action, including transportation activities between the quarry and chemical plant area. However, there is no need to restrict transportation activities to times of the day when school is not in session or at night. Transporting the bulk wastes to the chemical plant area and placing them into temporary storage can be much more safely performed during daylight hours; transporting them at night would be much more hazardous due to reduced visibility. An extensive environmental monitoring program will be utilized to ensure the health and safety of workers and the general public. The health of students and staff at the Francis Howell High School will not be compromised by implementing this action.

\section{Response G-4}

The need for a sorting pad at the temporary storage area is being reevaluated because the current plan is to conduct basic waste sorting at the quarry. Some limited sorting may still be required at the temporary storage area. Enclosing the sorting pad with an engineered structure is probably unnecessary; however, this consideration will be evaluated as engineering design proceeds.

Enclosing the entire quarry during excavation of the bulk wastes was considered in the preliminary engineering report and rejected due to its high cost. In addition, there is simply no need to enclose the quarry to remove the wastes safely. Radon and dust suppression measures will be implemented to ensure that releases of hazardous contaminants to the atmosphere will be low and not present a health risk to nearby individuals. 


\section{$62 / 63$}

\section{Kesponse $\mathbf{G - 5}$}

The temporary storage area will be located within the chemical plant area, which is surrounded by a fence. This area is located on the southernmost portion of the chemical plant ares and is not visible from highways or public access areas (i.e., the surrounding state-owned wildlife areas). Hence, there is no need to construct a 12-foothigh fence to keep unauthorized individuals from this area. The DOE will, however, consider the use of a solid fence at the north rim of the quarry to minimize visibility from State Route 94.

A 12-foot-high solld fence could reduce local airborne concentrations by a small amount, but most of the particles striking the fence would fall to the ground prior to reaching the site perimeter (especially in the direction of Francis Howell High School). Such a fence would not effectively reduce the emission of airborne contaminants that could migrate off-site. More effective measures --. such as water sprays, chemical surfactants, and covers -- will be used to minimize airborne emissions.

\section{Response G-6}

A preliminary evaluation of applicable or relevant and appropriate requirements (ARARs) is provided in Appendix C of the FS. The ARARs will be finalized in consultation with EPA Region VII and the state of Missouri, following selection of the alternative to be implemented. The walver condition mentioned on page 7-1 of the FS refers to specific requirements for final remedial actions, such as development of cleanup criteria. Development of cleanup criteria for the quarry is beyond the scope of this action but will be addressed in future documents following removal of the bulk wastes and completion of detailed characterization studies of the quarry area. Waiver conditions for cleanup standards are limited in scope and were established by the U.S. Congress in Section 121(d)(4) of CERCLA, as amended. This waiver condition is not a loophole that will be used to get around proper safeguards. The quarry bulk waste remedial action will be performed under the scrutiny of both EPA Region VII and the state of Missouri to ensure that it is done properly. 


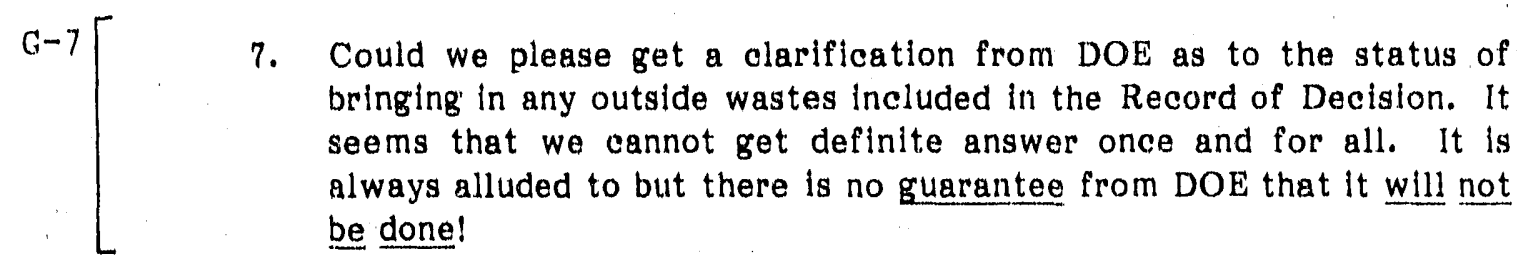

G-8 8. How of ten will air monitors be checked and by whom? Who will be notifled of a high reading and what other actions will be taken? What reading will be high enough to warrant action?

G.9 As you are aware, my major concern is the safety of the children and young adults at Francis Howell H.S. and Weldon Spring Sch. as well as those living in close proximity to the site. I am glad that you are so committed to a "safety-first" attitude, but I am concerned that if you are transferred or promoted, the new project manager may not share this attitude. Also, it is impossible to determine how many others involved in the project share your views in this matter. One person cannot possibly oversee every aspect of clean up and therefore, there are too many unforeseen problems that could occur.

I wish that it were possible for all the workers, subcontractors, and all of your staff to share these ideals, but humans, being as they are, make this an impossibility. They must be made to understand that their lives and the lives of our children are at risk for every slip-up or mistake or short-cut they take. The attitude of some of your own staff appears too blase about the risks assoclated with the contaminates they are dealing with. Maybe if their children were in these schools or down-wind from the site, they would be taken more seriously.

Thank you for considering my views.

Sincerely,

Linda N. Hoenig

50 Park Charles No.

St. Peter's, MO 63376 


\section{Response G-7}

The record of decision for this action is limited to inanagement of the quarry bulk wastes. Management of all wastes from cleanup of the Weldon Spring site is the subject of an ongoing RI/FS-EIS; a separate record of decision will be issued for that action. There are no plans to bring wastes from other areas to the Weldon Spring site for disposal. The record of decision for remediation of the chemical plant area of the Weldon Spring site will address the scope of waste disposal and will include provisions or limitations on use of the Weldon Spring site for future actions, as appropriate.

\section{Response G-8}

An extensive environmental monitoring program is currently in place at both the quarry and chemical plant areas. This program provides extensive information on the current status of these two areas. The monitoring program will be expanded at both the quarry and chemical plant areas prior to initiating the bulk waste remedial action. An operational environmental, safety, and health plan is currently being prepared that outlines the anticipated air monitoring program to meet the specific needs of this action. Air monitoring will be performed in three general areas: (1) the workplace (1.e., quarry and temforary storage area), (2) site perimeters (i.e., the quarry fence line and the perimeter of the chemical plant area), and (3) off-site sensitive receptor locations such as Francis Howell High School. Air monitors will be checked by on-site personnel. Although the details associated with this program have not been finalized (e.g., how often air monitors will be checked, individuals to be notified in the event of high readings, and levels warranting additional actions), the following information provides a brief summary of the planned program.

Air monitoring at the quarry and the temporary storage area workplace will be performed daily during work hours. Workplace monitoring is intended primarily to document potential worker exposure but also helps determine the effectiveness of engineering controls. Air monitoring at the site perimeters will be performed continuously. These monitoring results will be compared to applicable environmental release standards to ensure that bulk waste removal and temporary storage operations are being performed safely. Additional engineering controls will be implemented, if warranted, to maintain releases within applicable standards. In addition, work at the temporary storage area will stop and exposed areas will be covered if elevated concentrations are detected at Francis Howell High School. Work at the temporary storage area will not resume until the cause of the release is identified and corrective measures are implemented.

A number of engineering control methods are available to minimize the release of radionctive air particulates and radon, including water sprays, surface sealants, tarps, and uncontaminated soll. It is anticipated that one or more of these methods will be implemented constantly throughout the operation, regardless of alr monitoring results, in order to keep releases as low as reasonably achievable. These engineering controls will be upgraded and/or combinations of methods will be implemented if perimeter monitor-ing results indicate that the potential exists for exceeding environmental release standards. 


\section{$66 / 67$}

\section{Response G-9}

The DOE shares your vlews on the need to protect the health and safety of the students and staff at the nearby elementary and high schools. This action will not be initiated until detailed plans are in place to elusure that it can be performed safely. Safety and environmental protection are paramount in this and all other phases of the project. This attitude is shared by all personnel at the site and is not 11 mited to a single individual. 
Apri1 14, 1990

Stephen H. Mecracken, Project Manager

U.S. Departinent of Energy

Weldon Spring site Remedial Action project. Office

7295 HLghay 94 South

st. Charles, MO 63303

Dear steve,

I contacted Glen Newlown while you were out of town to see about an exterision of the comment perlod for the RI/FS materlals and Meeting on March 29, 1990. Glen called me back saying an informal extenston had been granted for Dr. Ayyagart and myself. SCCAHW needed an extenston for fout people, Dr. Ayyagari, George Farhner, Linda Hoenig and myself. So that Glen wouldn't have to call EPA again I contacted Bob Morby as Dan Wall was unavallable, and got approval for all four of us from him. I hope this meets with your approval.

I think that this most recont meeting was another "mutual experience" in our ongoing citizen/government. relationship. Before Weldon spring is ultimaliely remedied I'in sure we will have an even longer history of publiso meetings. So we still have time to perfect "the perfect public meeting," We haven't experienced the perfect one yet from the cltizens perspective.

H-1 [ As I gaid the eventing of March $29 \mathrm{th}$, I had recelved phone calls criticizing both SCCAHW \& DOE for scheduling an evening meeting for 7:00 pm. While this seemed to register with some of the state and federal offtclals (by their lacial expressions) as a rather trivial concerni I assure you that it is not to the people who want to atlend but cannol for the reasons stated.

Since the $29 \mathrm{th}$ I have recelved even more comments about. the early hour and the choice the location of the meeting. The comments break down as follows:

* MEETTNG - TIME: It ls traditional in st. Charles County to have evening meetings scheduled for 7:30-8:00, The main factor for this is very reasonable - most of the people that live in St. Charles County work in St. Louls and St. Louls County. Anyone who has experienced the stalled traffic on Hwy 70 from Hwy 270 to the Blanchetie (St. Charles) Bridge during rush hour traffic can at test to the fact that ror many it is almost impossible to get home early. All traffic in st. Charles County, whether it is Hwy 70,94 , or 40 has worsened; although Hwy 40 is not as bad unless it is Friday evening and people are heading for the lake of the Ozarks. Once home they need to eat a rushed dinner and then drive another 5 or 10 miles to the meeting in Wentzville. A 7:30 meeting at a more converient location would solve this problem - 8 would even be better, but $7: 30$ would be a good compromise. 


\section{Response $\mathrm{H}-1$}

The publio meeting was soheduled to begin at $7: 00 \mathrm{p} . \mathrm{m}$. so that it could be concluded without running too late into the night. The points ralsed in this letter are good reasons for scheduling future meetings to begin at $7: 30 \mathrm{p.m}$. Depending on the antiolpated duration, future publlo meetings will be scheduled to begin at $7: 30 \mathrm{p.m}$. 


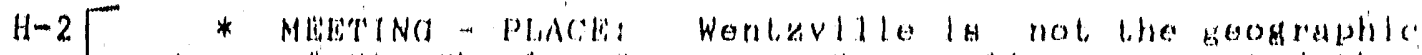
conter ol st. Charlos Counts. Some callora commented that "at Hight. they couldn't see whexe lo get off Hwy 70." You inght. think about contacting Dr. Bernle Dubray, superintendent of the fort Zurnwalt school blatilet to seo if 1t. would tre passlble to achedule the sept. or next. meoling at Forl "zumwalt South looated on Mextco Road In St. Peteris. It. is a new school that would be much mare oonventent to the St, Charles County population as a whole, and not far fram the st. Petorg Hollday ln for any incoming travelerg.

H-3 To schodule an important publte meeting at an Inconventent time and placo defeata the very purpose of what. DOE I a trying to achleve at these metheng - that being to Inform the publis and get thedr input on the proposed plans.

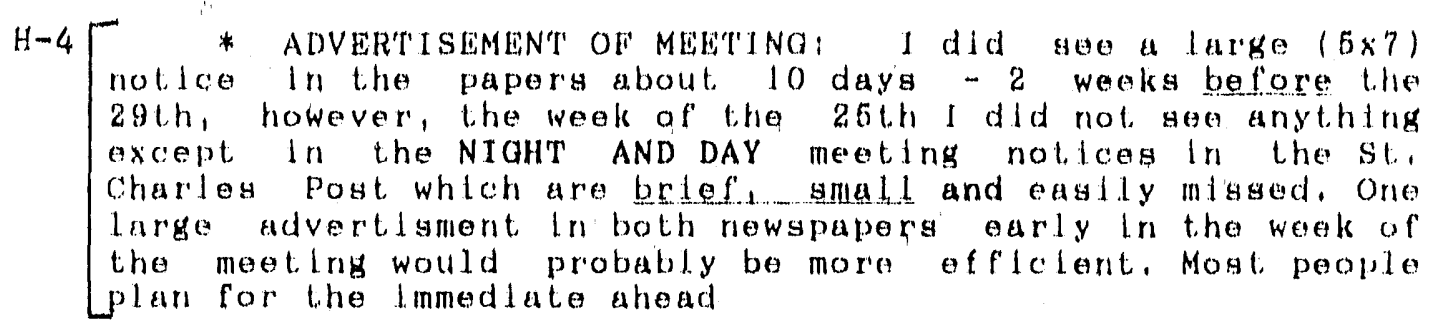

H-5 * MEETTNG Forma'l follow-up commenta to me were Indicators that people who had prepared statements would have llked the opportuntty to read what they had apent the $r$ lime preparling. Distlliling gtatements down lo questilons an cards that. Were then grouped with other cards doos not. adequately serve the purpose of a RI/Fs Public Meeting,

The process of "groupling" questions and assigning a gtate or federal agency representative to respond lo chem works very well at other information meetings, but in my apinion as well as others, if DOE is golng to the trouble and expense of having a stenographer at the "offlolal" hearing, then the resultant transorlpt. would be more understandable to later readers if the cilizens full thoughts and exact words were in the public record sud not gecind hand Interpretetions.

On March 2ath a majot screduling conflutet ocourredi it. was the game night as the prestiglous grand opening of st. Peters new olty Hall to elected county of'flotals. The sit. peters affalr started at 6:00 pri and was the reason thal. there were very fow elected county of fictals in attendarice at the RI/FS meeting at the Ramada In Wentzvldie. You would be surprlaed al how many people thought ihla was a dellberate ploy by bote. I tried lo assure them $1 \mathrm{t}$. was a colncidence.

Whenever the Dept, of Defense sohedules any current. meeting they check whth me to make sure that lhere are no 


\section{Response $\mathrm{H}-2$}

The Wentzville Ramada Inn has good facllitles for conducting publlo meatings and is located reasonably close to the Weldon Spring alte. The DOE felt that it was important to hold this meeting close to the site so that individuals who would be most affected by the proposed action would be able to atterd. As noted in thls comment; there are other facllitles that could be used. The DOE will try to schedule future publia meetings at fuollities that are close to the Welclon Spring site and accessible to as many people as posslble.

\section{Response H-3}

The DOE believes that the publlo meeting was soheduled at a conventent time and location to obtain publlo input on this aotion. However, we will consult wlth local offlolals during schedullng of future publto meetings.

\section{Response $\mathrm{H}-4$}

Large notloes advertlsing the publlo meeting were placed In local newspapers twice. The meeting was advertised in the St. Charles Journal on March 4, 1990, and in the St. Charles seotion of the St. Louls Post Dispatoh on Maroh 28, 1990. These two announcements provided sufflolent notice of the public meeting to allow Interested iridividuals to attend.

\section{Response $\mathrm{H}-5$}

The meating format was arranged to obtain publio Input on the proposed aotion. There are many people who do not feel comfortable speaking in a public forum. Use of cards allows these people to obtain information wlthout feeling intimldated by the need to ask thelr questions orally. This format also allows for an expedltlous exchange of information on specifio toples. Individuals who do not feel that their questions were properly interpreted or addressed can repeat their questions orally. In addition, any individual who does not wish to use cards but prefers to ask questions orally can do so within the format used for this meeting.

\section{Response $\mathrm{H}-6$}

The schedule for the publio meeting was coordlnated by DOE with EPA Region VII and the state of Missourl more than one month in advance. All three entities (as well as support contractors) arranged theil schedules to attend this public meeting. The DOE was not aware of the opening of the new clty hall In St. Peters, Missourl, on the same evening. There was no attempt made to keep the attendance low by scheduling the moeting to occur on March 29, 1990. Any county offlolal who could not attend the publlo meeting due to schedule confllots was still able to submit written comments on the RI/FS during the publio comment period. 
H-6 major conflitots that I know of alnee they did schedula and last year that even i sould not attend, I know only too woll how diffloult this is and that there wlll usually be "something," but offorts should bo made th the flutura bo asaure broador publito partiotpation. St. Charlos Counte's population is how almost 200,000 and good meeting preparation should produoe more than 50 people (after you subtract the DOS, Jacobs, MKF, EPA and state agendy (emp.loyees).

H-7 [**** DOCUNENT \& MEETING COMMENT RESPONSE TIME: In DOI'A dacument OR/21598-106 the Proposed Plan f'or Management...... an page 16 under Communty partidation atreseses the Lmportance of pubilita revlew of documenty and comment for the offlolal record. T'o do this adequately a longer response the pertod ta necessary, 1 have no doubly about this.

In 1987 at the DEIS mootling April 10th the comment. pertod was to May 5 th $(25$ day response t.Jme) and extenstons were "avallable" if needed. The recont RI/lis meeting on March 29 th announoed a comment pertod that ended Aprit ath thls is only 11 days!

H-8 * No'te: Meoting held for the goul of communtty information and response should not be scheduled in late March or early April. Citizeng are busy preparing their Income taxes, and ang meeting and document reading have to take a back soat to tncome lak return preparation.

H-9 [ * NOTE: In your proposed Plan document - 105 it puls forth six proposalg with a preferred allernative seemingly pre-selected?? In thelr comments to me oitizens have wondered if thelr input counts for anything - especially if they would disagree with the preferred alternative.

In closing I have commenta on the following ltems:

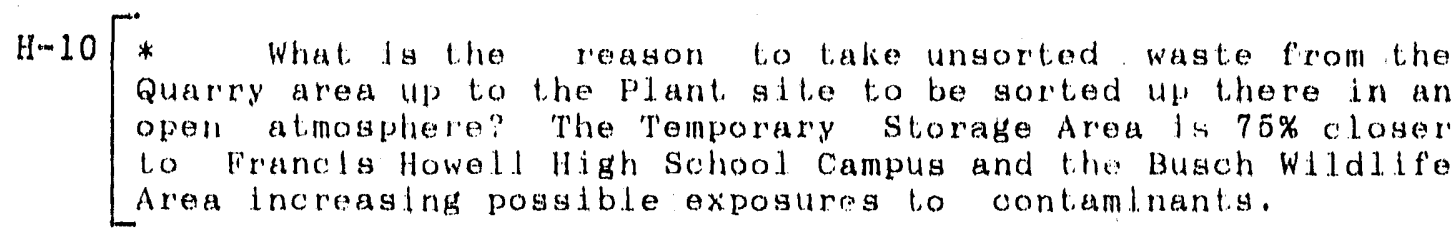

H-11 [* I do not think that any waste removal and transport. should be inlated as an intertm remedial action as the pululito safeguards are less than if they are performed after the Record of Decision.

H-12 * When Guarry wastes are moved why can't it be moved by rall road? The NRC deolded that ratl was the safeat form of transportion for the high level waste from three Mlle Island as it crossed the United States.

I all very famlliar with Mo. State Highway 9 a betweon the Quarry and the weldon Spring chemical plant. Ir the elght. years that I have been involved with Weldon spring and Have had many occastons to travel that particular routio. During 


\section{Response $\mathrm{H}-7$}

The RI/FS documents were issued to the general public on March 5, 1990, and the public comment period extended to April 9, 1990. The public meeting was scheduled to occur near the end of the public comment period. The public comment period was 35 days in length, not 11 days. A 30-day public comment period is required for actions of this nature under CERCLA. The comment period was actually longer than required.

\section{Response H-8}

The DOE and EPA Region VII feel very strongly about the need to remediate the Weldon Spring site. The RI/FS was issued to the public immediately upon completion. A public comment period is required upon issuance of the RI/FS to the public. Release of the documents was not timed to occur during the time period that many citizens were preparing their income tax returns.

\section{Response H-9}

The DOE has not yet reached a decision on implementing Alternative 5 . However, this alternative is preferred by DOE. A joint EPA/DOE record of decision will be issued this year documenting which alternative will be implemented.

\section{Response $\mathrm{H}-10$}

The DOE has revised its conceptual plans for removing the wastes from the quarry and has developed a strategy that will allow for the wastes to be sorted at the quarry. Some sorting may still be required at the temporary storage area. This limited sorting can be safely performed at the chemical plant area with minimal risk to nearby individuals and the environment.

\section{Response H-11}

Delaying this interim remedial action would postpone the attainment of remedial action objectives at the quarry (e.g., to respond to ongoing releases by removing the primary source of contamination from the quarry and to initiate necessary characterization activities). The preferred alternative can be implemented in a manner that will not endanger students and staff at Francis Howell High School or any other individuals in the area. The extensive monitoring program currently in place will be expanded prior to initiating the proposed action to ensure the health and safety of nearby residents and the environment.

The DOE is currently preparing an RI/FS-EIS to evaluate alternatives for the permanent disposal of all wastes generated by remediating the Weldon Spring site. Although the RI/FS-EIS will be available for public review and comment in 1991, the length of time to implement permanent disposal options will take several more years. Delaying the proposed removal of the bulk wastes would result in continued, uncontrolled release of contaminants to the environment in the quarry area. The proposed action is being taken at this time to respond to this release. 
H-12 this time the traffic on liwy 94 has continued to increase dramatically. Why take the risk?

The major part of st. Charles County's phenoninenal growth is in the West/South West area of St. Charles County. Several years ago there would be spells of time when no traffic went past the Quarry, but not anymore!

There is also the hazard of the other local quarry's 30 ton trucks that need to use that stretch of Hwy 94 . If DOE's 40 additional trucks use Hwy 94 for return trips to the Quarry are added to the dally use tally combined with Hwy 94 being a two lane, extremely winding highway without ANY shoulders and you have all the ingredients of an accident waiting to happen because the FAC'TS ARE:

1. The Dept. of Energy cannot ban the Quarry trucks or traffic.

2. The Dept. of Energy cannot stop the residential growth of the region.

3. The Dept. of Energy cannot change the topography of the stretch of highway between the Quarry and the plant area.

4. Howevar, the Dept. of Energy can re-evaluate the option of railroad transport and its potential safety features.

Please accept this information as well intentioned problem solving exercise that will increase the level of trust and communication that we, as citizens, have tenuously established with the U.S. Dept. of Energy. As long as we can openly communicate in order to bring about a safer, speedier cleanup of the Weldon spring site, we are doing exactly what all responsible citizens need to do to work within. the process of our United States government. As SCCAHW TAG project manager, I feel a certain sense of responsiblility to make NEPA, RCRA/CERCLA, or whatever, understandable and workable from the citizens standpoinl.

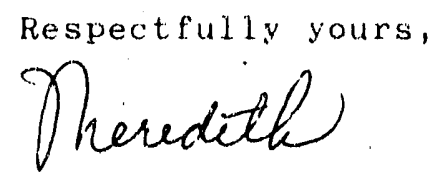

Meredith Hunter Bollmeier SCCAHW, TAG Project Manager. 


\section{Response $\mathrm{H}-12$}

The rail spur between the quarry and chemical plant area is in a state of disrepair and would require a significant amount of effort (and cost) to upgrade for use. The results of a recent detalled cost estimate indicate that the rail option would cost about $\$ 1$ million more than the haul road option. In addition, this rail spur crosses State Route 94 three times between the quarry and chemical plant area. As currently planned, a dedicated haul road will be constructed using a portion of the existing railroad easement. This haul road will cross State Route 94 only at the quarry; discussions with the state of Missouri are currently taking place on the use of grade separation at this location to eliminate all crossing of Route 94 by trucks.

As presented in the FS, loaded trucks would transport the bulk wastes to the chemical plant area on a dedicated haul road. The return trip to the quarry would be on State Route 94. However, the increased operational flexibility associated with using containers could allow for the return of empty trucks along the haul road. Plans for the haul road may need to be modified to include several turnouts which, in conjunction with radio contact, would allow safe passage of truck traffic. This would eliminate all truck traffic on Route 94. 


\section{Letter I}

This hand-written letter was typed verbatim for clarity of presentation. The original letter is available for inspection at the DOE office at the Weldon Spring site.

May 9, 1990

Mr. Stephen H. McCracken, Project Manager

U.S. Department of Energy

Weldon Spring Site Remedial Action Project

7295 Highway 94 South

St. Charles, Missouri 63303

\section{Dear Mr. McCracken:}

First, before I begin I would like to express my thanks to Mr. Robert Morby, Chief of Superfund Branch, U.S. Environmental Protection Agency, Region VII for the time extension granted to SCCAHW for written comment on the Quarry Plan to be included as part of the Administrative Record for consideration in the Record of Decision.

The following listed areas are addressed in priority order for implementation before the clean up phase begins at the Weldon Spring Quarry.

I-1 [1. Relocate all people living in the surrounding areas that are affected by increased background radiation which is produced by the Quarry waste materials before clean up activities begin. This includes the people living near the Quar'y Site as well as those near the proposed haul route \& the Temporary Storage Site (TSA) at the Weldon Spring Chemical Plant specifically Francis Howell High School. This would include the buyout of those properties adversely affected by this increased background radiation. The public safety must not be compromised by the off site migration of radioactive \& other hazardous substances contained in the Quarry waste. (Figure 3.3 \& Figure 10.1 Attached pages)

I-2 [2. Relocate the St. Charles County Public well field to an area that can be safety relied upon to provide a constant supply of clean water. St. Charles County Residents deserve nothing less than responsible decisions regarding a safe water source. The existing wells are located below the Quarry Site. These should be capped \& monitored for possible transfer of contaminated materials from the excavation process. If you wait until the radiation level at the county well field goes above background levels or state standards, \& then decide that it's unsafe, it well be too late to protect the public. The publics health \& safety cannot be sacrificed for lack of proper management in the area! (Figure 1.5 \& Figure 3.10 Attached pages) 


\section{Response I-1}

There is no need to relocate individuals or institutions (i.e., Francis Howell High School) in the vicinity of the Weldon Spring site to safeguard them from releases from either the quarry or chemical plant area. An extensive environmental monitoring program is currently in place at both areas. This monitoring program indicates that the areas being impacted by the releases are confined to the immediate vicinity of the quarry and chemical plant areas. The concentrations of radioactive and hazardous chemical substances in environmental media at of $\mathrm{f}$-site locations are not high enough to cause health concerns under current land-use patterns.

The analyses contained in the RI/FS documents indicate that the preferred alternative can be implemented in a manner that will not endanger nearby individuals. The existing environmental monitoring program will be expanded at both the quarry and chemical plant areas prior to initiating the bulk waste remedial action to ensure the health and safety of nearby residents and the environment.

\section{Response I-2}

There is currently no need to consider moving the St. Charles County well field because the water from this well field is not contaminated. This well field is being extensively monitored by federal, state, and local authorities. The DOE intends to increase its monitoring efforts during the bulk waste remedial action to ensure that this action does not result in contamination impacting the well field. Monitoring of the well field will continue following removal of the bulk wastes from the quarry while studies are undertaken to evaluate the need for additional remediation of this area. Because the monitoring wells are located between the quarry and the well field, remedial actions can be taken in a timely manner, if required, to safeguard the quality of water in this well field. 
Page 2

May 9, 1990

I-3 3 . Construct an enclosure for the Quarry Site designed to include:

A. Interior compartments for lsolation \& controlled release of radon gas.

B. Roof structure based on orest of highwall around quarry rim with pillar support from base of limestone hill near center of quarry site.

C. Double air lock entry/exit system for men \& machinery with decontamination facilities for transportation vehicles after loading for shipment, (i.e. remote wash down sprayer). (Figure 1.3, Figure 2.2, Figure 4.16) Attached pages

I-4 4, Refurbish existing rail spur from the Quarry to the Weldon Spring Chemleal Plant for rallroad transport of the Quarry waste. Preliminary studies indicate that this rail spur is of standard gauge \& is intact with the following exceptions: (See attached photos \& maps of same)

A. 50 feet rall \& tie section missing

B. $34^{\prime}$ length $x 12$ ' Depth wash out area

C. Bad switch at Water Treatment Plant \#1

D. 2 switches \& rall sections missing at Hwy 94 road crossing at Quarry Site

E. 3 Road crossings on Hwy 94 covered with asphalt

F. Verification needed on track storage area, existing rall, rall cars and/or locomotive at the Weldon Spring Chemical Plant.

G. Rallroad tie replacement as needed for those which have weathered and deteriorated (accurate survey required).

A comparative cost estimate for repair \& rebulld of this rail line is necessary! This analysis should involve the total cost estimate for removal of the rail line for truck use as a haul route compared to refurbishment of the existing rall for train transport of the quarry waste materials. (Figure 1.2, Figure 1.6, \& Figure 8.7) Attached pages

I-5 5. Burlington Northern Railroad, the closest avallable rall service to the Weldon Spring Quarry Site, has expressed a definite interest in further evaluation on transportation of the quarry waste to the Weldon Spring Chemical Plant. The rallroad should be given every opportunity to competitively bid on transportation of the quarry waste materials. 


\section{Response I-3}

Enclosing the entire quarry during excavation of the bulk wastes was considered in the preliminary engineering report and rejected due to its high cost. In addition, there is simply no need to enclose the quarry to remove the wastes safely. Radon and dust suppression measures will be implemented to ensure that releases of hazardous containlnants to the atmosphere will be low and not present a health risk to nearby indlviduals.

\section{Response [-4}

The DOE appreciates the information provided on the current status of the rail spur between the quarry and chemical plant area. As noted in this comment, several sections would have to be rebullt. In addition, the rail spur has not been used for many years and would require thorough revlew, repair, and confirmatory testing before it could be used to transport the bulk wastes. This option would be very expensive and timeconsuming to implement. A detalled cost estimate was recently performed in response to this comment. In this evaluation, the total cost of rall transport, including materialhandling facllities at both the quarry and temporary storage area, was compared with the total cost of truck transport, including construction and use of a dedicated haul road. The rall transport option was estimated to cost about $\$ 1$ million more than the truck transport option. This option was dismissed due to its excessive costs with no meaningful risk reduction. Truck transport of the bulk wastes is the most efficient and costeffective means of moving the bulk wastes from the quarry to the chemical plant areas.

\section{Response I-5}

The Burlington Northern Railroad has expressed an interest in transporting the wastes from the Weldon Spring site to Richland, Washington, or an alternate destination. The railroad has not expressed an interest in transporting the bulk wastes from the quarry to the chemical plant area. The existing rail spur between the quarry and chemical plant area is in a state of disrepair and would require a significant amount of effort (and cost) to upgrade for use. In addition, this rail spur crosses State Route 94 three times between the quarry and the chemical plant area. Each crossing presents a safety concern. The wastes can be safely and efficlently transported by truck along a dedicated haul road that will be constructed using portions of the existing rail spur. The dedicated haul road will cross State Route 94 only once (near the quarry). Discussions are currently taking place with the state of Missouri on the use of grade separation where the heul road crosses State Route 94. This would eliminate all crossing of Route 94 by trucks.

As presented in the FS, loaded trucks would transport the bulk wastes to the chemical plant area on a dedicated haul road. The return trip to the quarry would be on State Route 94. However, the increased operational flexibility associated with using containers could allow for the return of empty trucks along the haul road. Plans for the haul road may need to be modifled to include several turnouts which, in conjunction with radio contact, would allow safe passage of truck traffic. This would eliminate all truck traffic on Route 94 . 
Page 3

May 9, 1990

I-5 As a public safety issue the amount of tonnage estimated to be removed from the Quarry equals 248,00 toris of materlals (Appendix B see attached pages). 'The 11,800 trips by truok needed to haul this estimated 248,000 tons can be moved by train. with only 310 trips at 8 (100 ton) ralloars per train! This represents a substantial reduction in the number of trips required to move the quarry waste. This translates into a great beneflt as far as publlo safety is conoerned regarding reduced trafflo hazards \& potential for accidents. Other beneflts of rallroad transportation Include:

(1) less delay due to inclement weather conditions that would otherwise render temporary shut down of operations (l.e. trucks on an unpaved surface af ter rain),

(2) eliminates pothole problem on an unpaved surface (1.e., no road grader needed),

(3) ellminates tire fallure due to, l.e. (truck weight on out of round tires or puncture of tire causing a flat),

(4) easier decontamination of rall cars (1.e. high pressure water sprayer against steel wheels \& rall car body),

(5) reduces potential for driver error during hauling of waste materlals (1.e. rall line itself acts as a guide mechanism to follow the haul route) (Figure 9 \& Figure 10 Attached pages)

I-6 6. NEPA Regulations: According to the regulations for Implementing the National Environmental Polley Act as of July 1, 1986 specifleally Title 40 of the code of Federal Regulations Part 1506.1(c)(3). The Dept. of Energy shall not undertake any Interim action which will "prejudice the ultimate decision" on the program. (i.e. Cleanup of the Weldon Spring Quarry Site) Interim action prejudices the ultimate decision on the program when it tends to determine subsequent development or $11 \mathrm{mit}$ alternatives,

For the Dept. of Energy to transport bulk wastes from the quarry and dump them in a plle at the Temporary Storage Area (TSA), and then add a radon cap of dirt above that, would make it more likely that this massive quantity of radioactive waste \& other hazardous wastes would remain permanately at the TSA. On the other hand, to place the excavated quarry bulk wastes in a MARK III Bin or slmilar appropriate container (Before transport and storage of the containerized materials at the TSA) would be more in compliance with 40 CFR 1506.1(c)(3).

By the same token, removal of the existing rall line spur between the Quarry Site \& the Weldon Spring Chemical Plant, (so the DOE can move the quarry waste material by truck over the gravel roadbed), this action would also violate NEPA 40 CFR 1506.1(c)(3) by determining subsequent development for truck hauling \& would limit alternative shlpment to only one source (i.e. trucks being the only method of transport). This action would also clrcumvent any railroad involvement 


\section{Response Im6}

Limitations on Interim actions that can be undertaken while an Eis is in preparation are given in 40 CFR 1506.1. Remedial action alternatives for the chemioal plant area of the Weldon Spring site are being evaluated in an Rl/FS modlfled to incorporate the requirements of an EIS. This Integrated CERCLA/NEPA approach is being referred to as the RI/FS-EIS process. A major element of the RI/FS-EIS is a decision on the appropriate mearis to dispose of all wastes generated by remediation of the Welclon Spring site. The quarry bulk waste remedial aotion will be unclertaken in a manner that wlll not bias the decision-making process for the RI/FS-EIS.

Relocation of the bulk wastes from the guarry to the chemleal plant area will not blas future decisions for waste disposal. The scope of this action has been focused to ensure that the action complies with the constraints imposed by $40 \mathrm{CFR} 1506.1$. Removal of the bulk wastes from the quarry wlth transport to and temporary storage at the ohemical plant area is an Interim action being taken to reduce ongoing releases of radioactive and chemically hazardous substances into the environment at the quarry area. This action will not prejudice the final decision for remediation of the Weldon Spring site.

There are several means by which the quarry bulk wastes can be safely removed, transported, and temporarlly stored at the chemical plant area. Neither bulk storage nor containerized storage will blas the selection of the final disposal alternatives for these wastes. Simllarly, converting portions of the existing rail spur to a dedicated haul road for truck transport of these wastes will not bias future decisions. If analyses in the RI/FS-EIS demonstrate that off-site disposal is the best solution for management of the wastes resulting from remediation of the Weldon Spring site, additional studies wlll be performed to determine the optimal means for transporting these materials. Use of rall for transport of these wastes off-site is very unlikely given the recent dismantlement of the Missourl-Kansas-Texas rall line in the vicinity of the Weldon Spring site and construction of the Missouri River State Trail. Converting portions of the rail spur between the quarry and chemical plant area into a dedicated haul road will not blas future decisions or $11 \mathrm{mit}$ alternatives being evaluated in the Rl/FS-EIS. 
Page 4

May 9, 1990

I. -6 for elther temporary storage or permanent disposal of the total waste to be removed from the Weldon Spring Site at a future date. To prejudice the ultimate decision agalnst transportation by rall service oannot be tolerated in this time of publlo need for a safe solution to thls hazardous waste problem!

I-7 7. The Dept. of Energy should allow Independent inspectlong during the oleanup of the Weldon Spring Quarry. This would address the need to monltor the operational procedures and verlfy compllance with all Federel, State \& Local County requirements being met as work progresses. An appointment of an unblased oversight committee with the power of enforcement is necessary to control any violations should they ocour.

Sincerely,

George A. Farhner

892 Calffornla Trall

St. Charles, Mo. 63303

Weldon Spring Quarry Waste Removal Projeot

cc: U.S. Senator John Danforth

U.S. Senator Christopher S. Bond

U.S. Representative Harold Volkman - 9th Dist.

- Mo. State Senator Fred Dyer

Mo. State Representative Joseph Ortwerth - Dist. 18

Mo. Governor John Asheroft

U.S. EPA Region VII Robert Morby

Mo. Dept. of Natlonal Resources Dr. David E. Bedan

St. Charles Countians Against Hazarclous Waste

Coalition for the Environment

Burlington Northern Rallroad 


\section{Response I-7}

All response actions undertaken by DOE at the Weldon Spring site are reviewed by EPA Region VII and the state of Missourl. Both entitles provide Independent oversight of DOE actions. In addition, because the Weldon Spring site is on the National Prloritles List, EPA, not DOE, has ultimate responsibllity for ensuring that appropriate actions are taken at the site to safeguard human health and the environment. The DOE welcomes Independent review of their aations by altizen groups. However, there is no need to appoint an oversight committee with the power of enforcement to ensure compllance with all federal, state, and local requirements. 


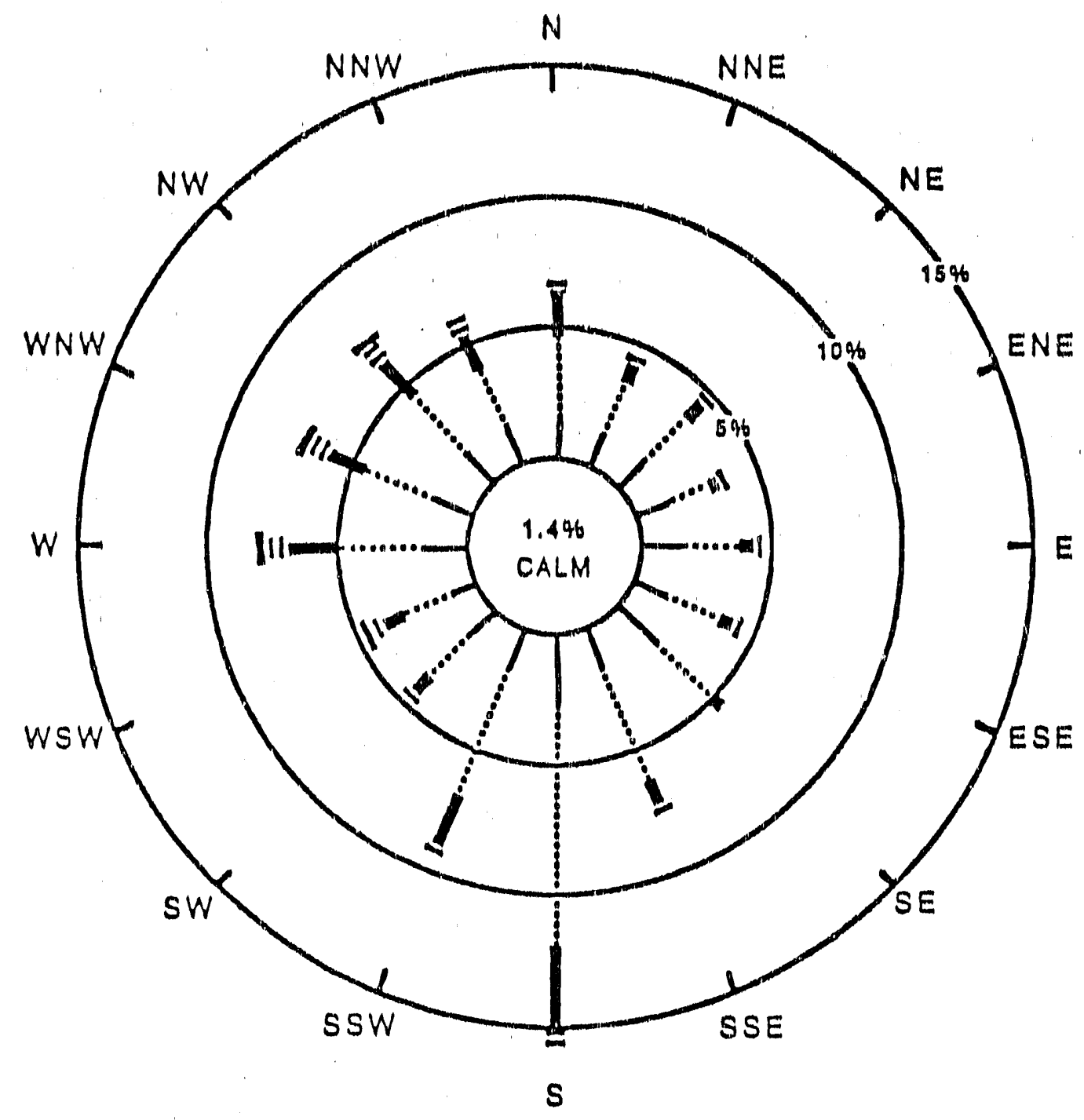

NOTE:

BASED ON DATA FROM

WELDON SPRING SITE

METEOROLOGICAL

STATION DURING 1980.

WIND SPEED

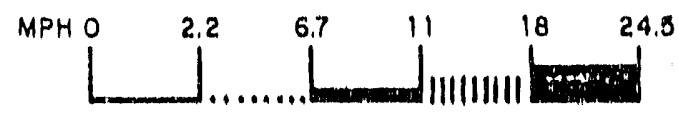

FIGURE 3.3

ANNUAL WIND ROSE FOR THE WELDON SPRING SITE 


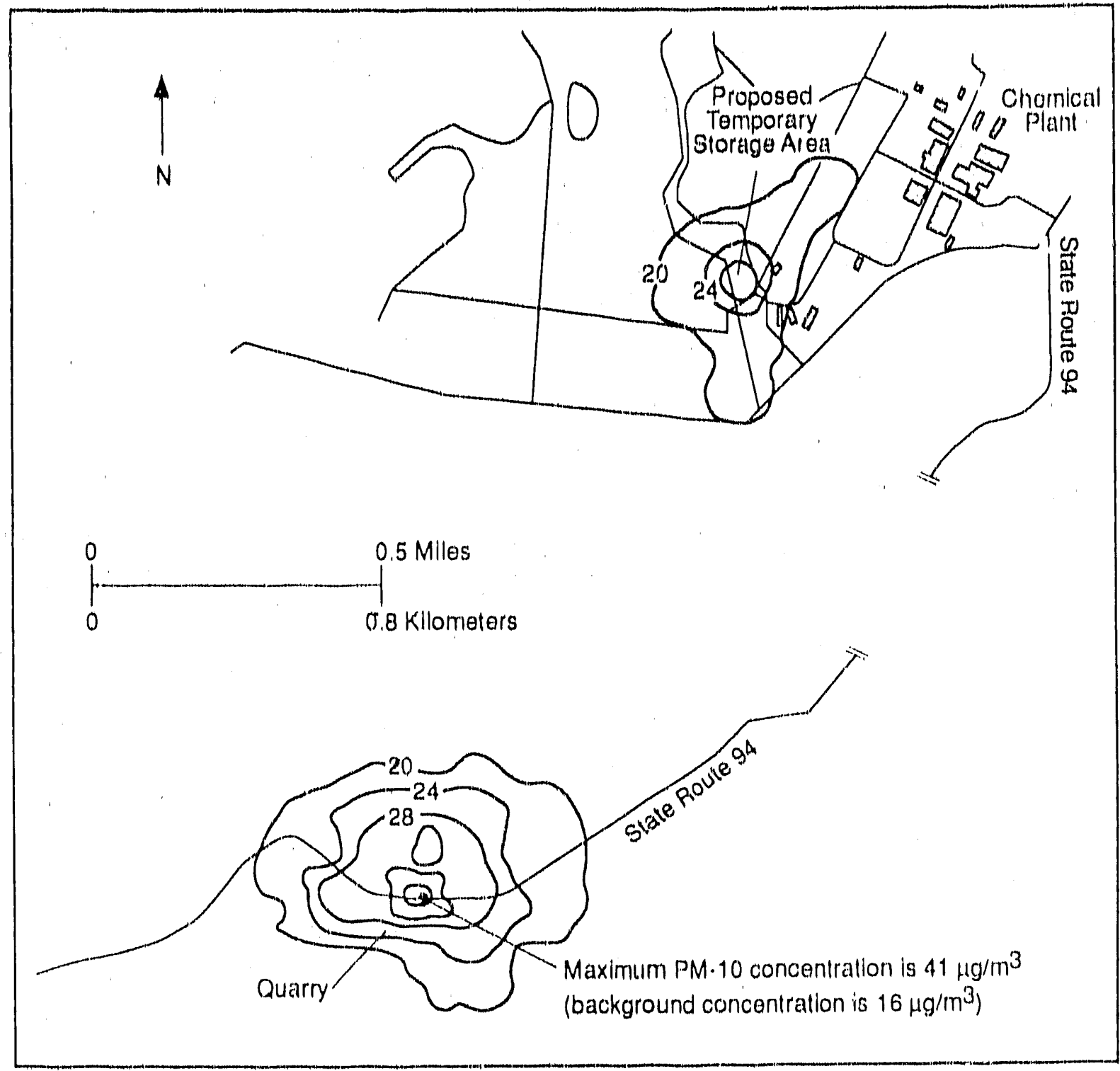

PIGURe 10.1 Estimated Total Annual Mean P M-10 Concentrations $\left(\mu g / \mathrm{m}^{3}\right.$ ) Resulting from the Bulk Waste Remedial Acstion (does not include estimates for the area naar the western TSA fence line)

Concentrations of airborne particulates cannot be predlcted accurately for receptors alose to a source of fugltive dust. However, because the subarea for finegrained, nitroaromati-contaminated solls at the TSA could be olose to the fence line (e.g., about $15 \mathrm{~m}(50 \mathrm{ft})$ ), the 24 -hour and annual total PM-10 concentrations at the fence line could be elevated. Concentrations above the 24-hour standard are predicted to ocour at three receptor locatlons: the property fence lina, $30 \mathrm{~m}(100 \mathrm{ft})$ west of the fence line, and approximately $100 \mathrm{~m}(300 \mathrm{ft})$ south of the contaminated-solls area. Maximum concentrations are estlmated to be $388 \mathrm{~kg} / \mathrm{m}^{3}$ at the receptor west of the 


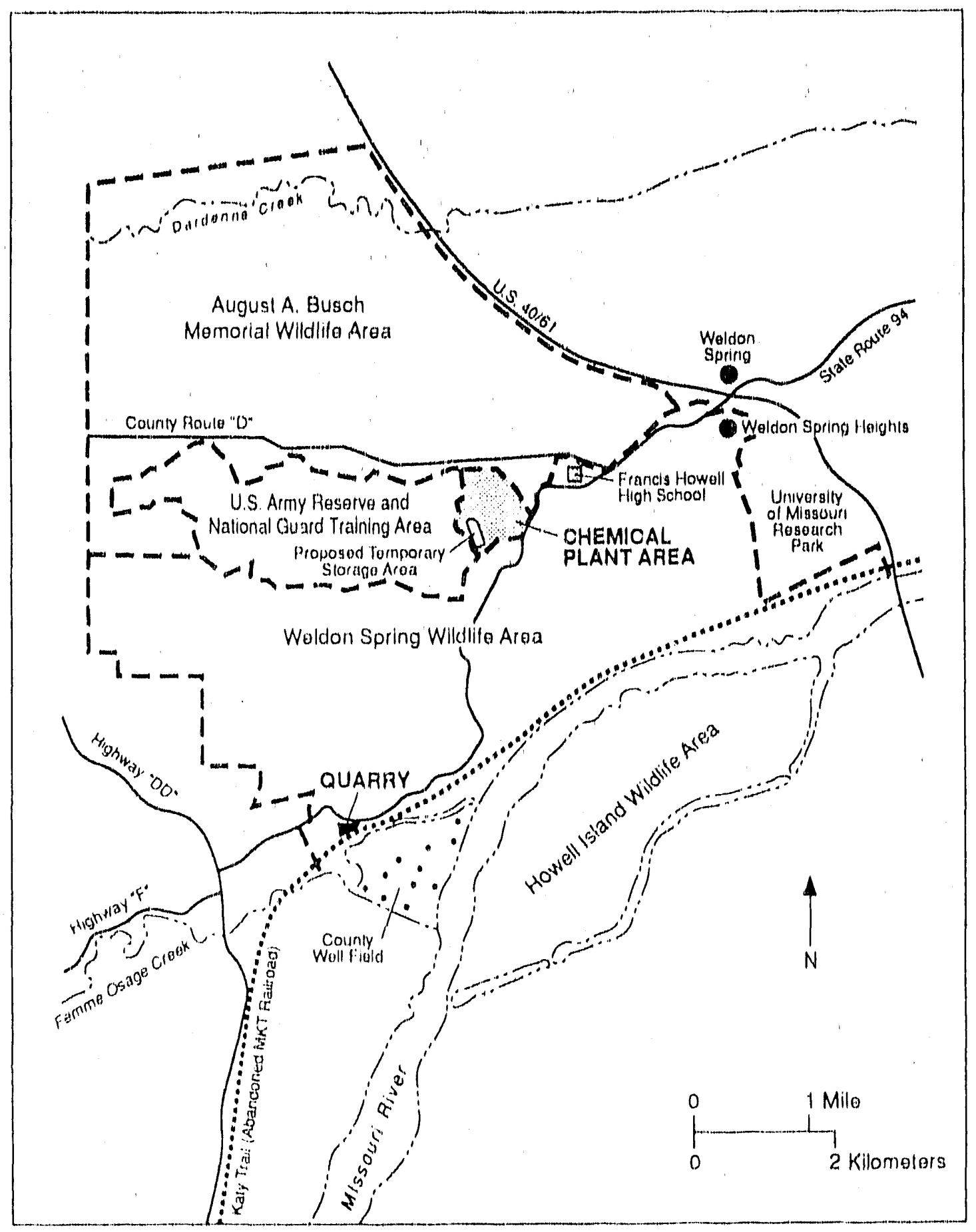

FIGURE 1.5 Map of the Weldon Spring Site and Vicinity 


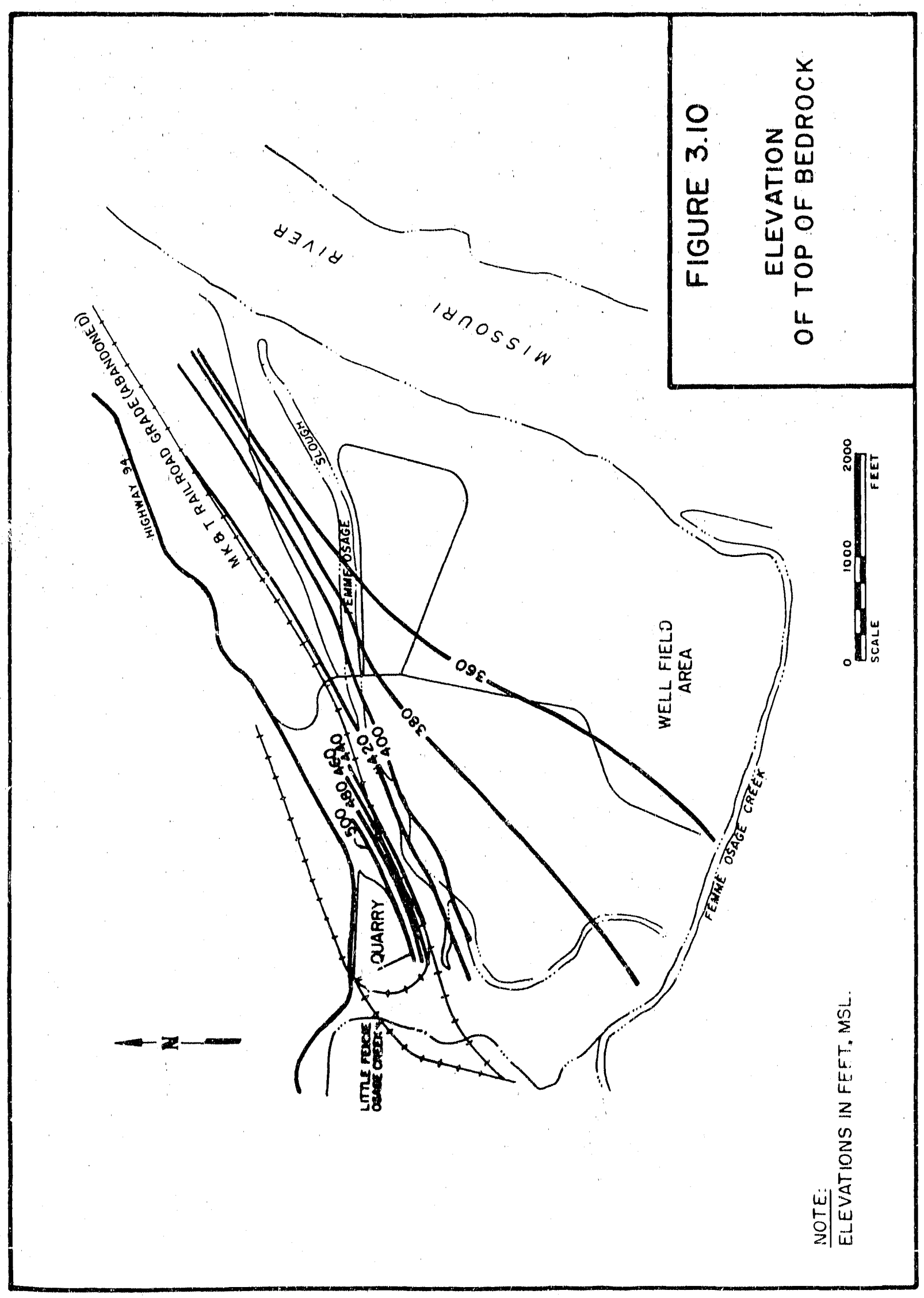




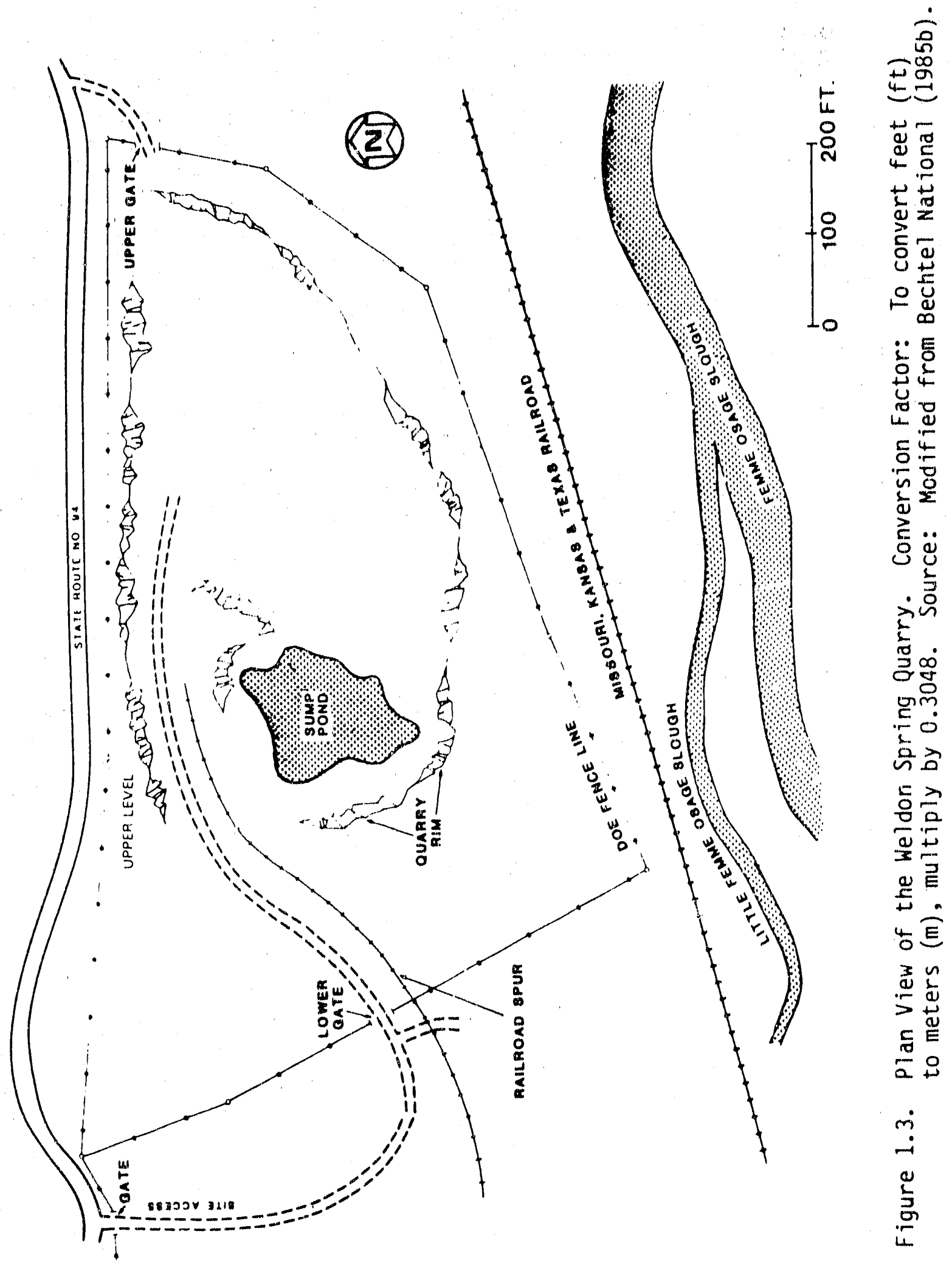




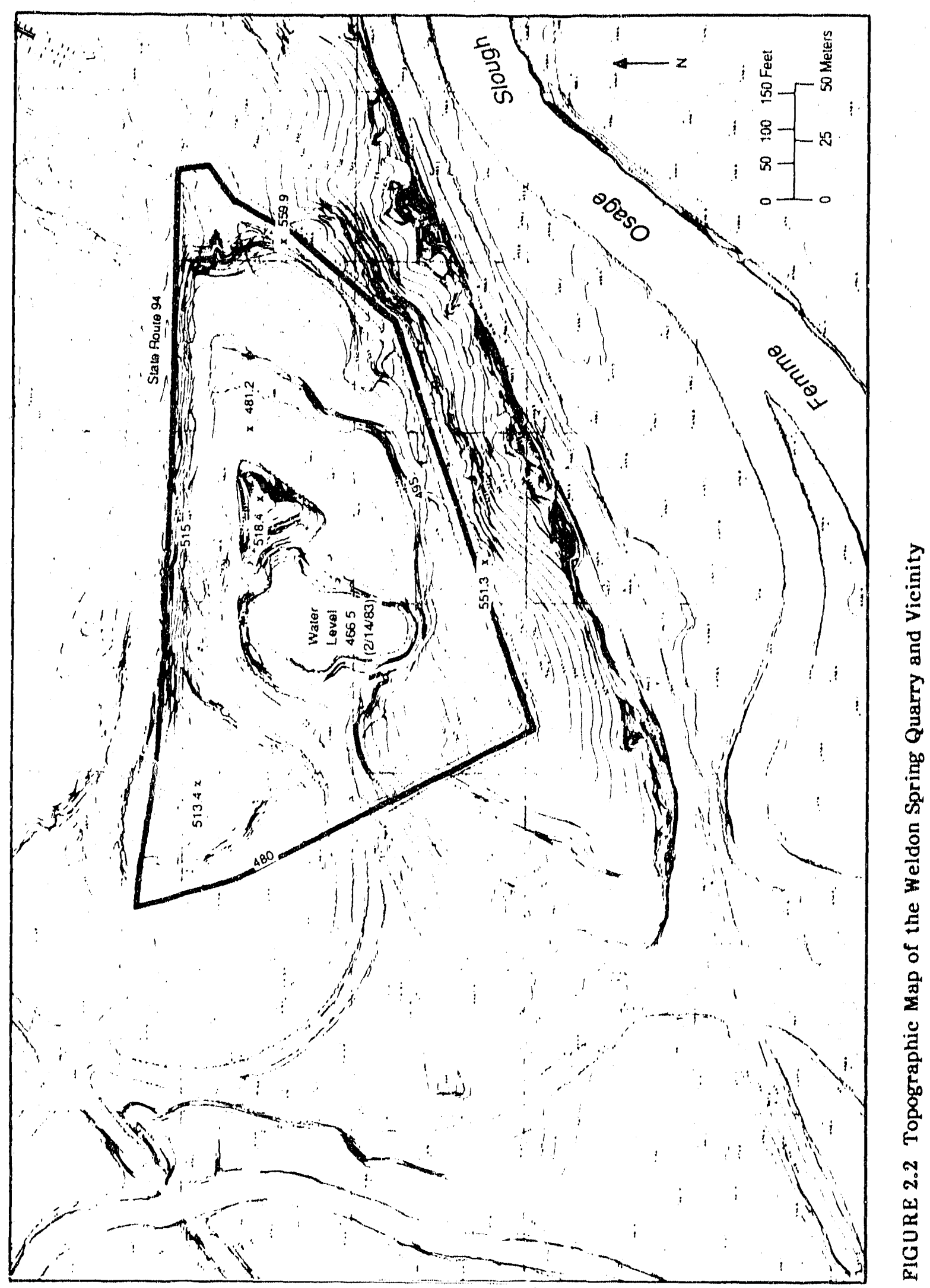




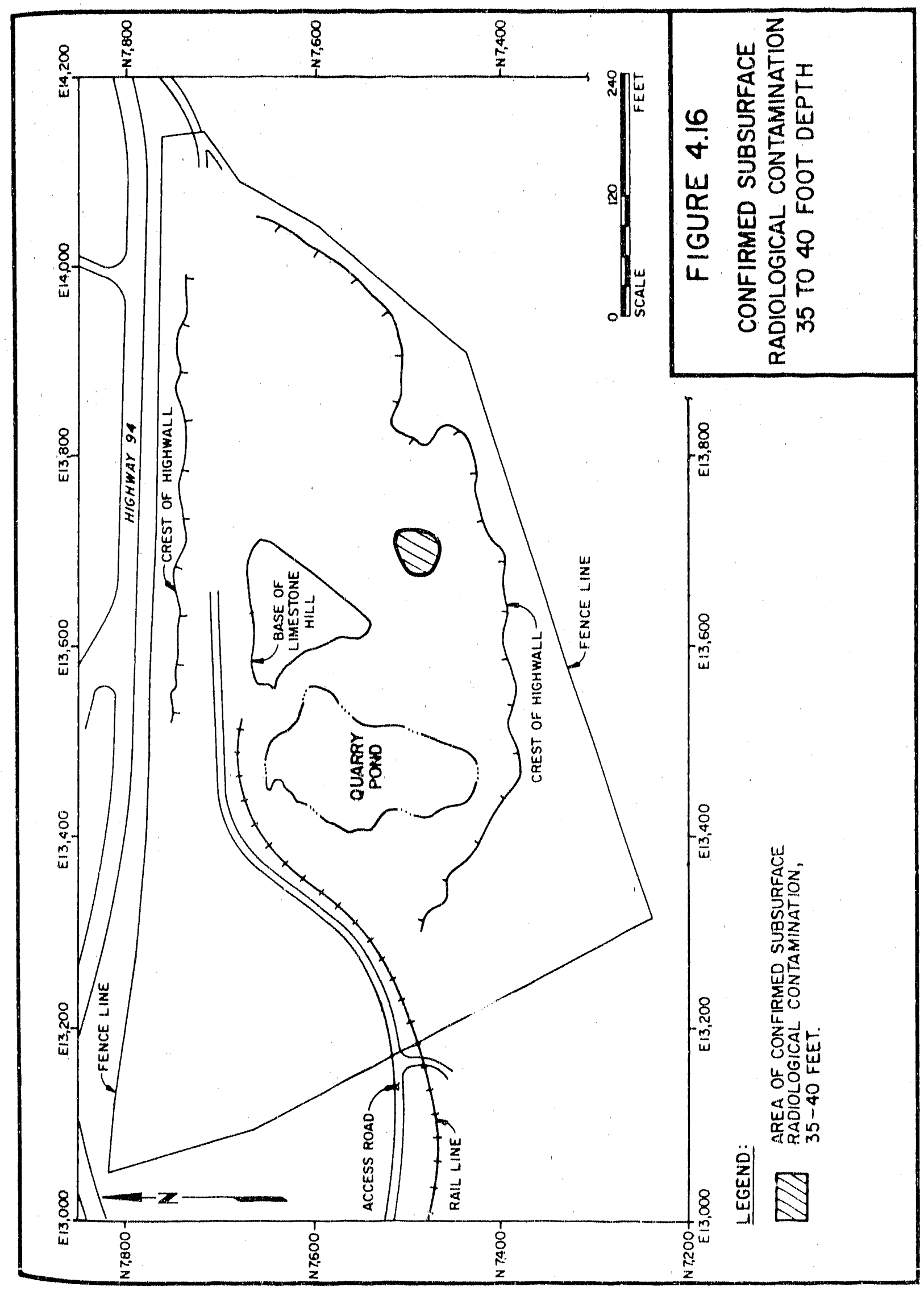


91

$1-3$

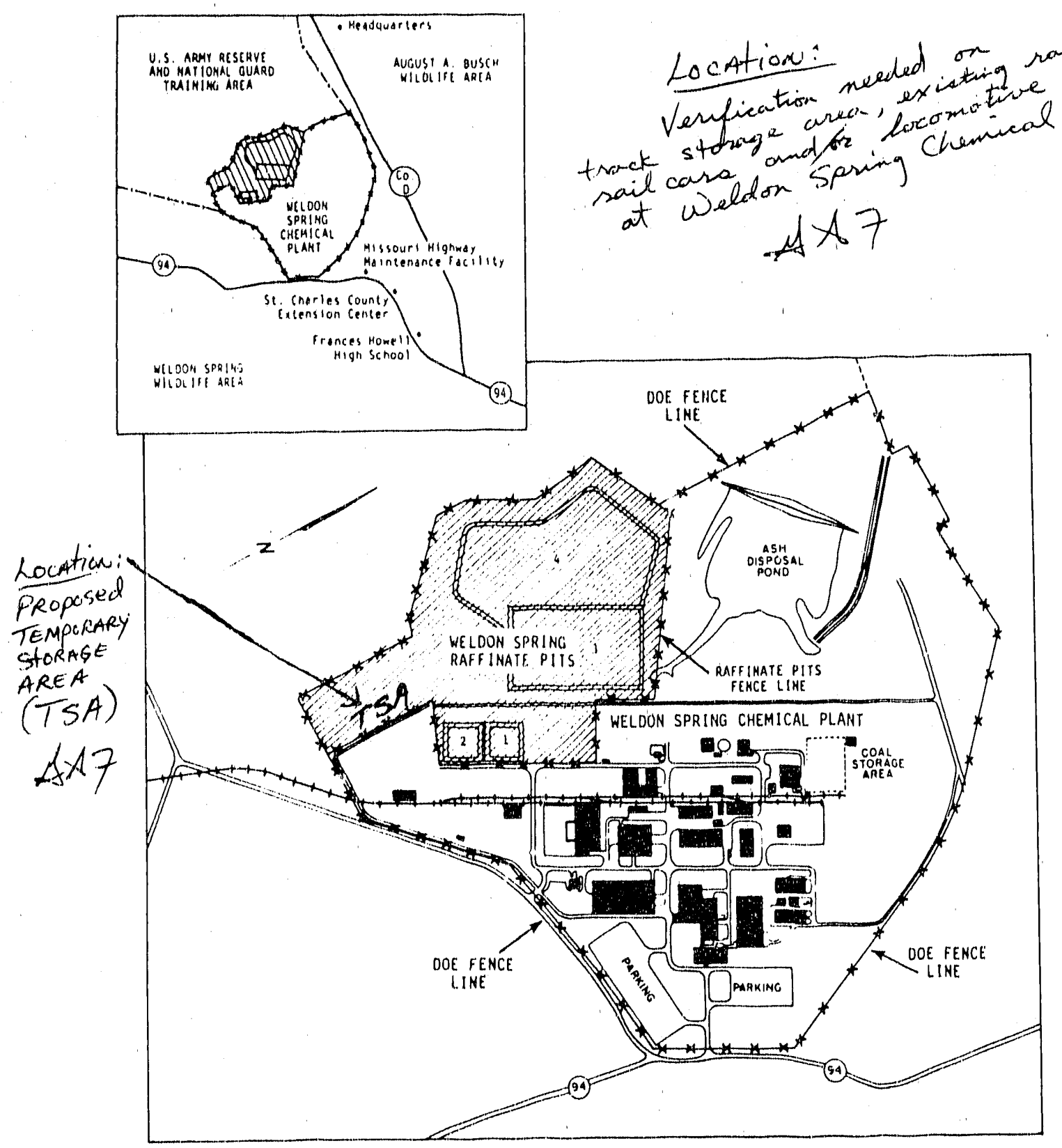

Figure 1.2. Location and Layout of the Weldon Spring Raffinate Pits and Chemical Plant. Source: Modified from National Lead Company of Oh lo (1977).

* Mf t shows writers notes added to Figure 1.2 


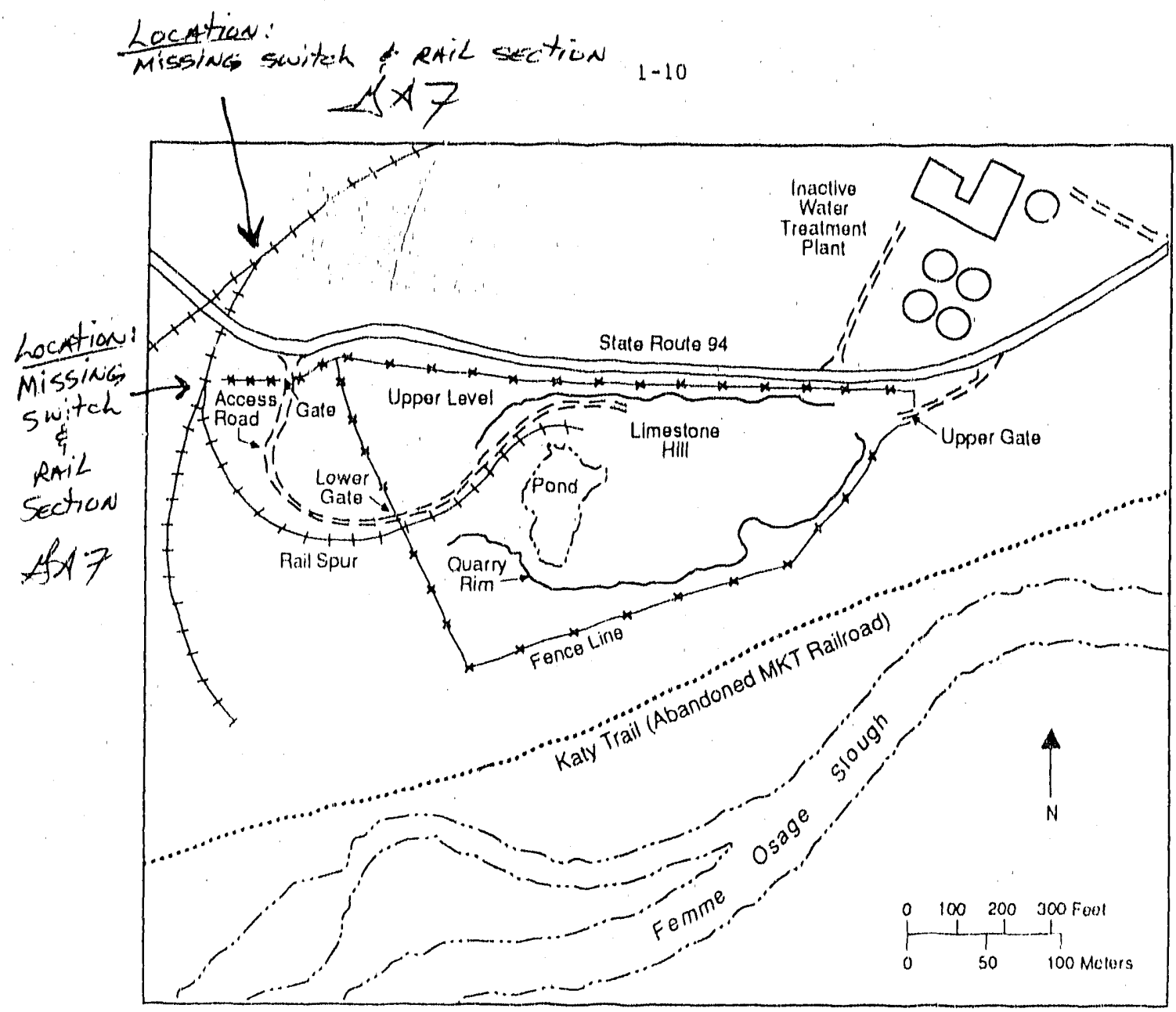

PIGURE 1.6 Layout of the Weldon Spring Quarry

810 ha $(2,000$ acres) had been transferred to the state of Missouri (August A. Busch Memorial Wildlife Area) and the University of Missouri (agricultural land). Much of the land transferred to the University of Missourl was subsequently developed into the Weldon Spring Wildlife Area. Except for several small parcels transferred to St. Charles County, the remaining property became the U.S. Army Reserve and National Guard Training Area.

The U.S. Atomic Energy Commission (AEC, a predecessor of DOE) acquired 83 ha (205 acres) of the former ordnance works property from the Army by permil, in May 1955 , and the property transfer was approved by Congress in August 1956. An additional 6 ha (15 acres) was later transferred to the AEC for expansion of waste storage capacity. The AEC constructed a feed materials plant - now referred to as the chemical plant -- on the property for the purpose of processing uranium and thorlum ore concentrates. The quarry, which had been used by the Army sirce the early 1940s for disposal of chemically

$$
\text { * IA } 7 \text {, show writars votes }
$$


93

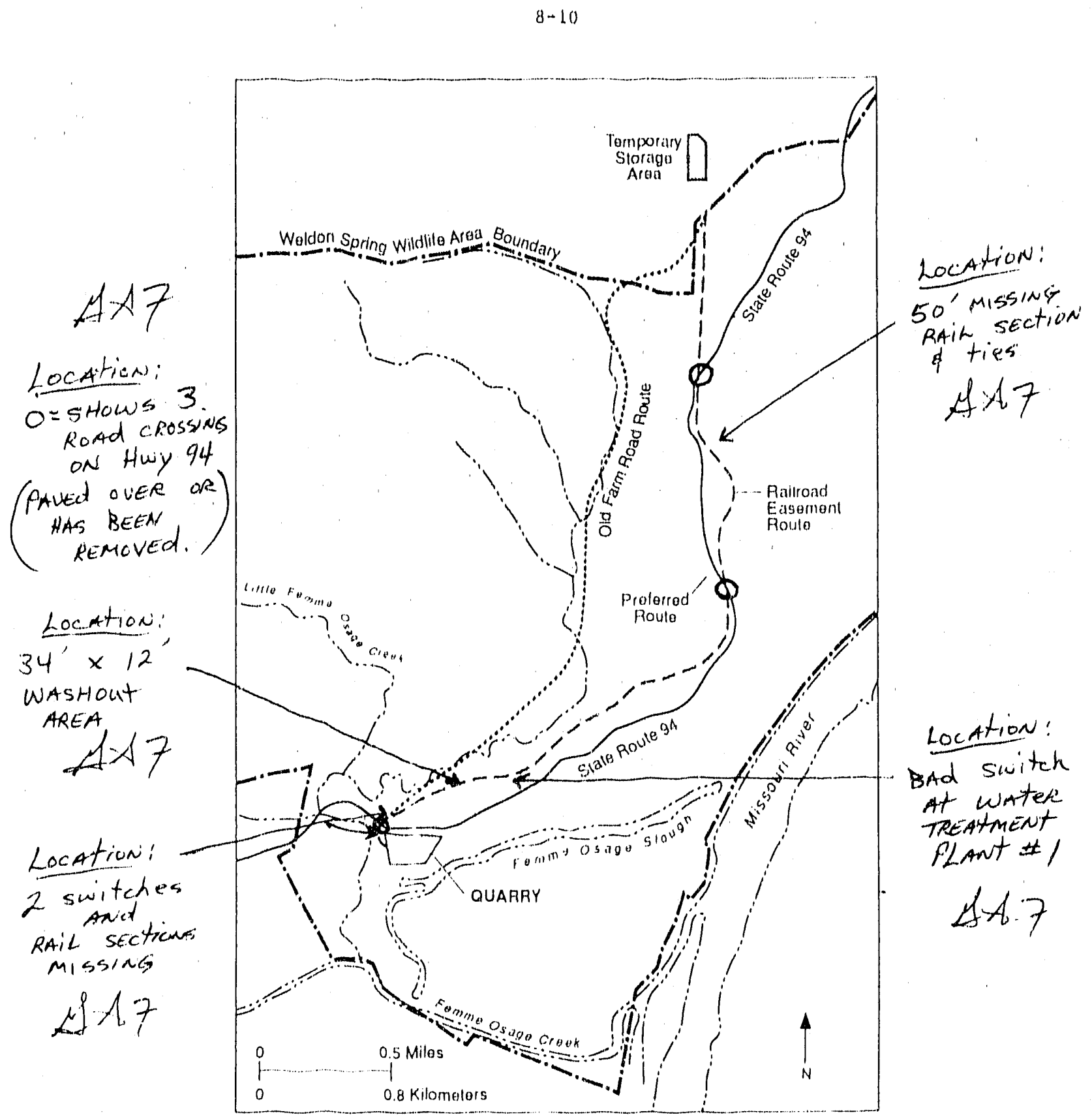

FIGURE 8.7 Preferred and Alternate Haul Routes to the TSA

* \&177, shows writers notes Added to map Figure 8.7 


\section{APPENDIX B:}

\section{ANALYSIS OF POTENTIAL AIR QUALITY IMPACTS}

The approach used to predlat alr quallty lmpacts of the bulk waste remedial action is presented in thls appendix. Section B.1 descrlbes the methodology used to prepare both the long-term (annual) and short-term (dally) unoontrolled PM-10 partioulate emission Inventories and to convert the results into appropriate input for the predictive alr quallty models. Section B.1.1 ldentlfles fugitive dust sources. Seotlons B.1.2 and 83.1.3 address the annual uncontrolled Inventory and the worst-case dally uncontrolled inventory of PM-10 emissions, respectively. Section B.2 identifles representative strategies for fugltive dust control assumed in the analysis, and Section B.3 summarlzes both the uncontrolled and controlled PM-10 emission Inventorles. For simpllalty of presentation, most units in this appendix are given In English unlts only; conversion factors are provided in Appendlx D. Those data originally measured in metric unlts (i.e., meteorologloal clata) are expressed in metric units.

The alr quallty analysis was based on the following speolflo assumptions concerning how the bulk waste remedlal action would be conducteds

1. The dally number of haul trips averaged over all workdays during the project would be 40 (Ferguson 1989).

2. The dally maxlmum number of haul trucks would be 48 (Ferguson 1989; MK-Ferguson Company, and Jacobs Englneering Group 1990).

3. The number of hours of heavy equlpment use would be $11 \mathrm{mited}$ to 8 hours per day and 5 days per week, l.e., no overtime would be employed.

4. A loaded truck would weigh no more than 40 tons; the maximum bulk waste load would be about 21 tons based on manufacturer ratios of capacity to tare weight.

5. Assuming an average bulk waste density of 2 tons per banked cuble yard (bcy) and a potential 124,000 bcy of material to be moved ( $\mathrm{MK}$-Ferguson Company and Jacobs Engineering Group 1990), 248,000 tons of materials would be moved in about 11,800 trips.

6. The average volume of materials hauled from the quarry would be 10.5 bcy or 11.9 loose cubic yards (ley), assuming a 21 -ton capacity truck, an average density of 2 tons/bcy, and an estimated 1.13 ley/bey (Mk-Ferguson Company and Jacobs Engineering (Group 1990).

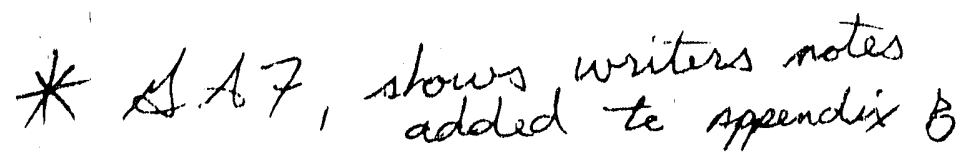

$$
\begin{aligned}
& \text { 8OC: TON } \\
& \text { PER } \\
& \text { DAY -ity } \\
& \text { CAPACITLS } \\
& \text { EQUALLS }
\end{aligned}
$$

8<smiles>[Mg][Mg]</smiles>

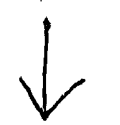




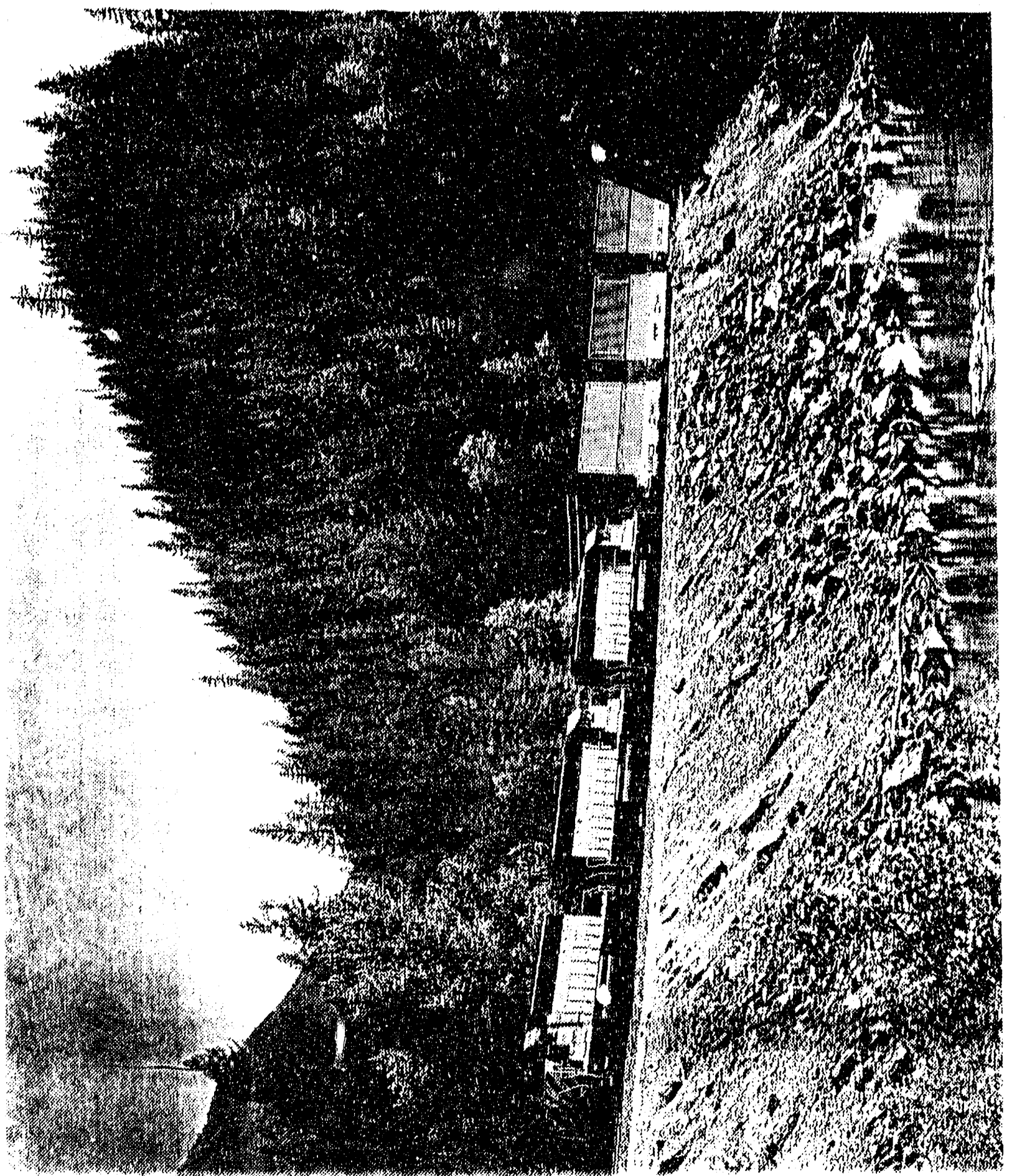

Figure 9 

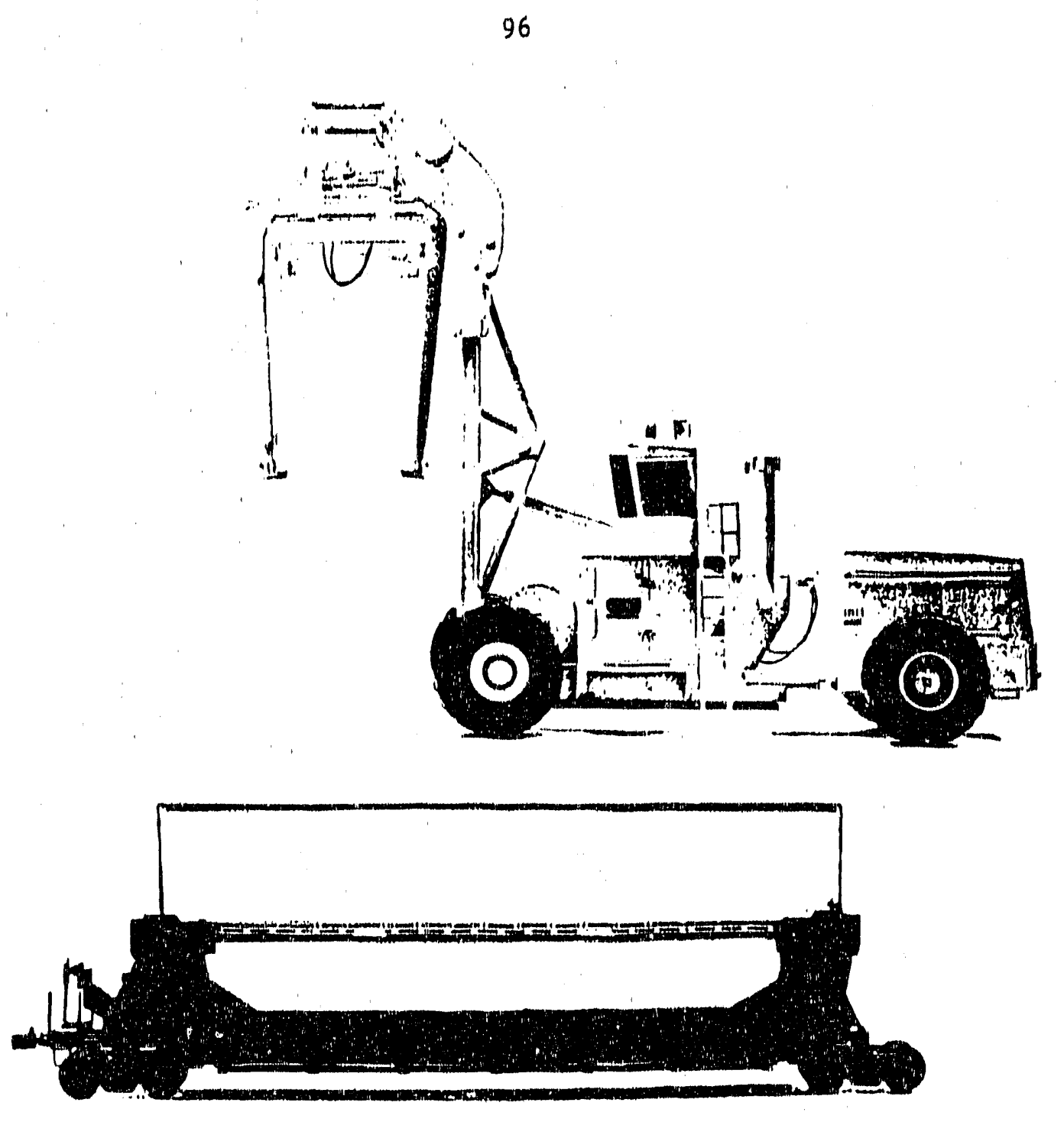

Figure 10 


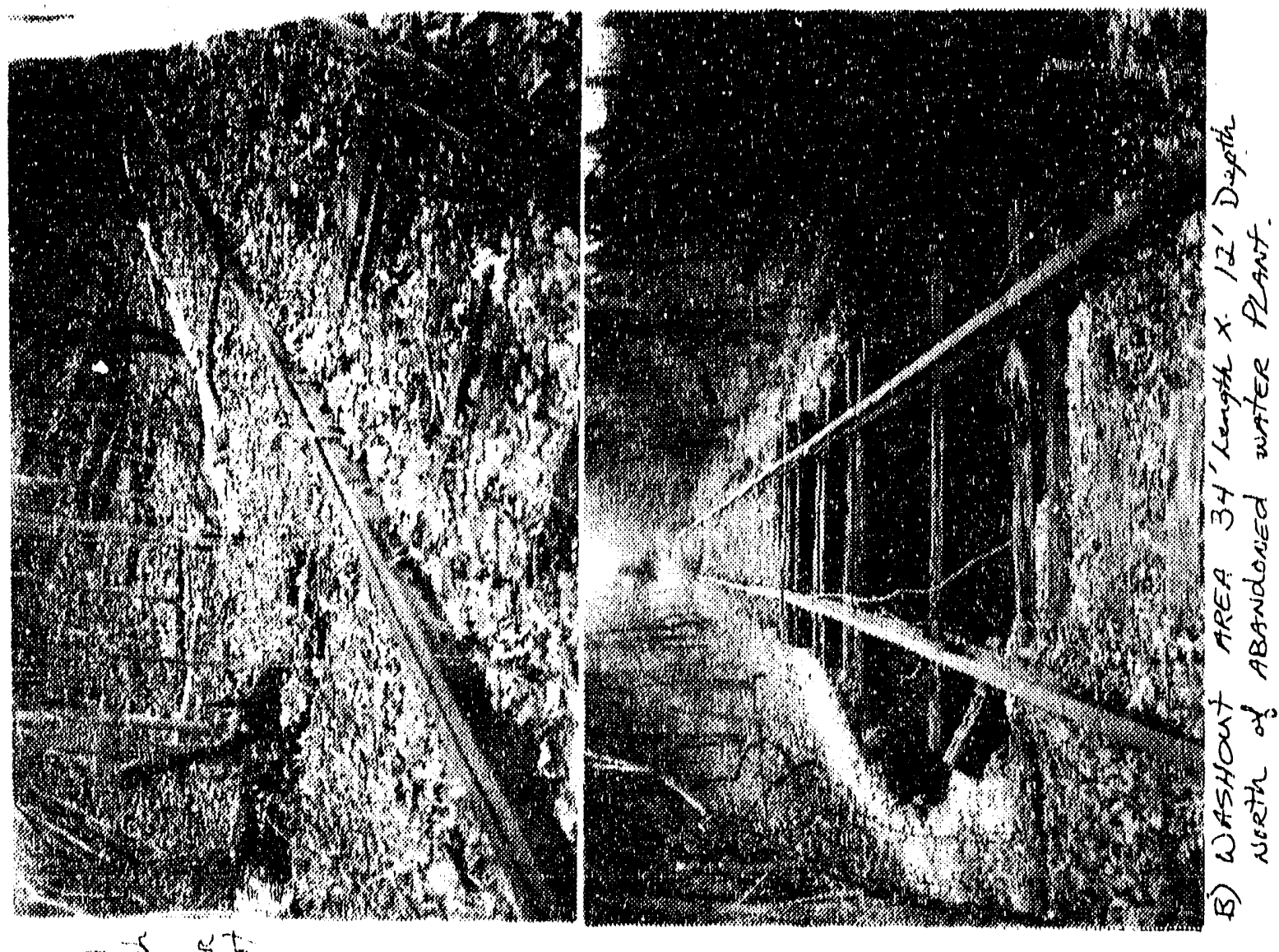

(1) 90 के
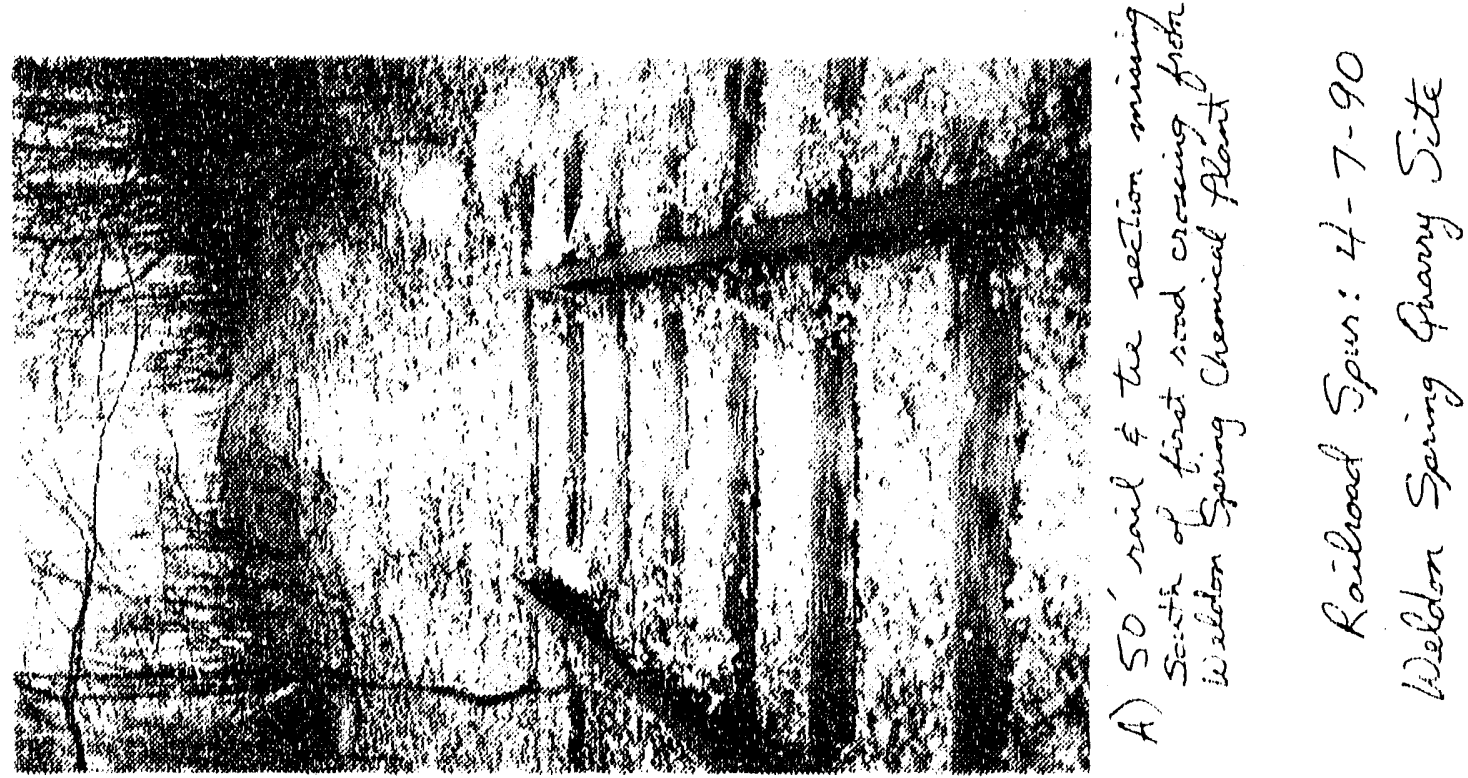


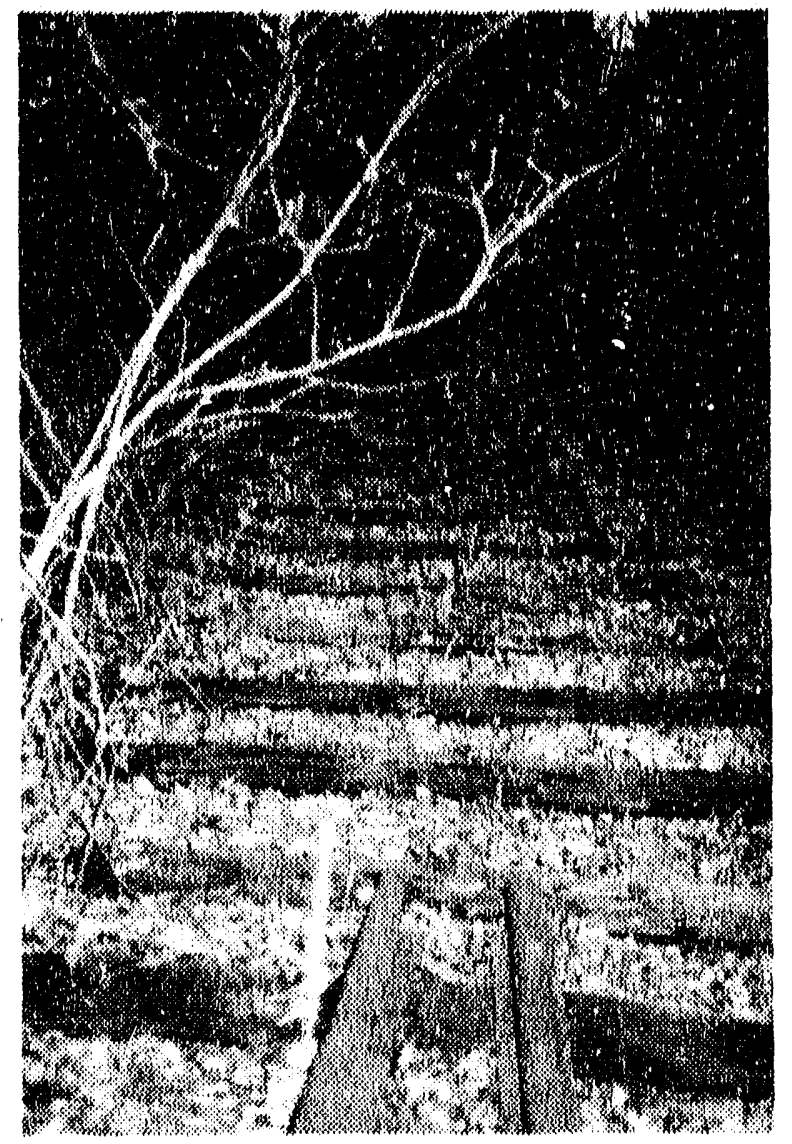

$$
\begin{aligned}
& \text { Railrand Spur: 4-7-90 } \\
& \text { Welidon Spring Quarny Site } \\
& \text { D.) Mising rail aection, } \\
& \text { "Froe", Noreth of } \\
& \text { Quarry road croading } \\
& \text { at Hwy } 94 \text { South. }
\end{aligned}
$$

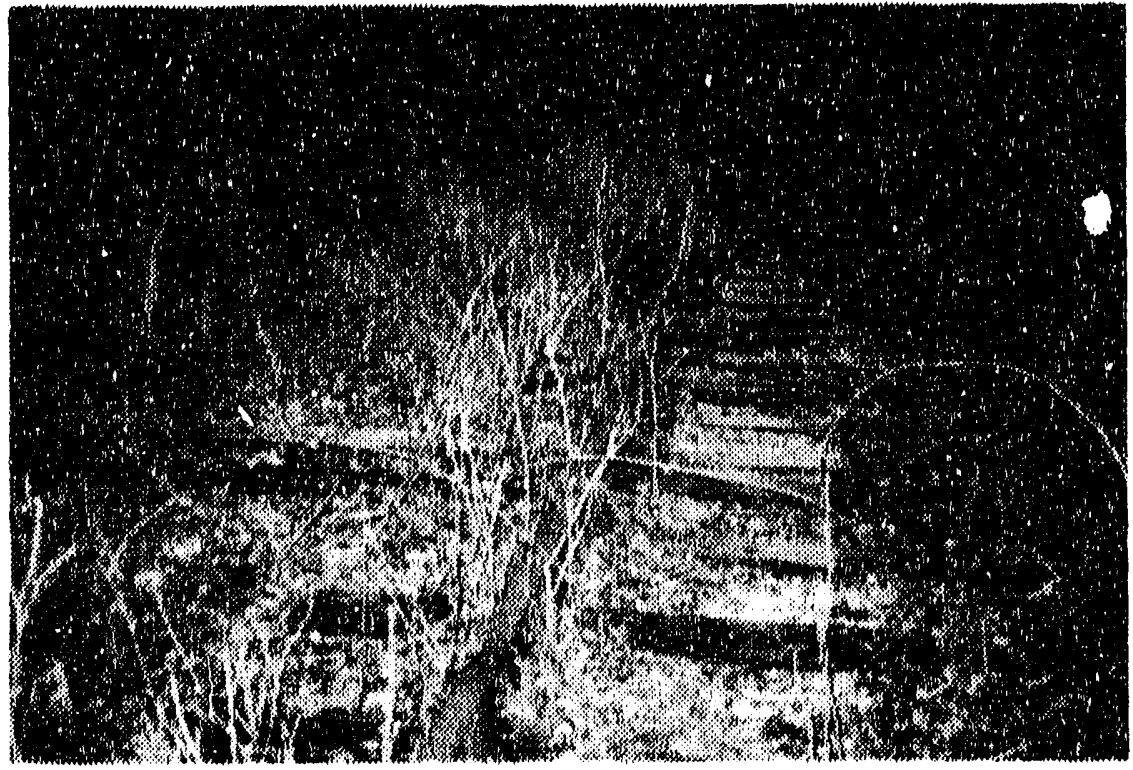

D) Musing writch

North of Quarny road Hwy 94 South 


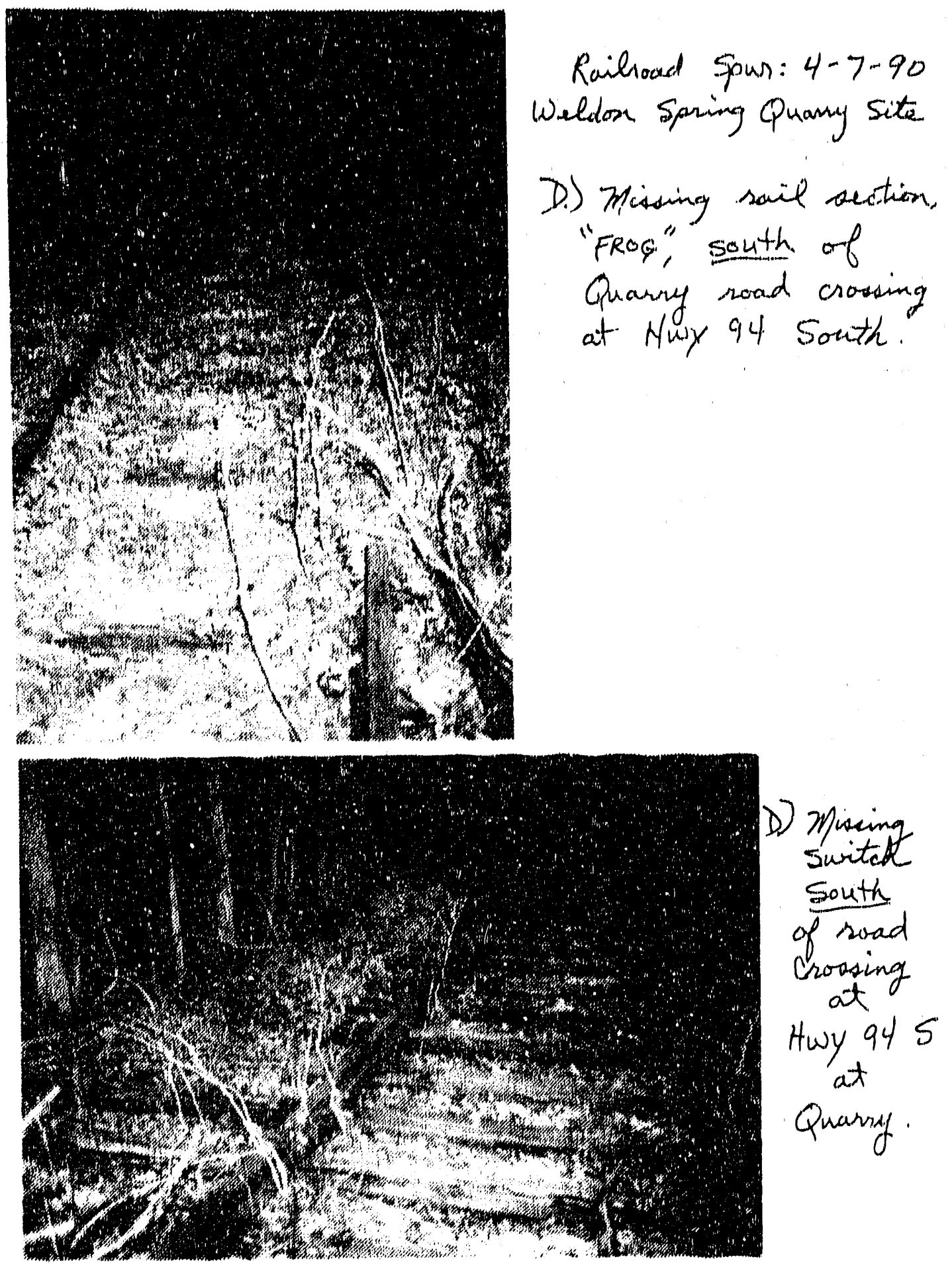




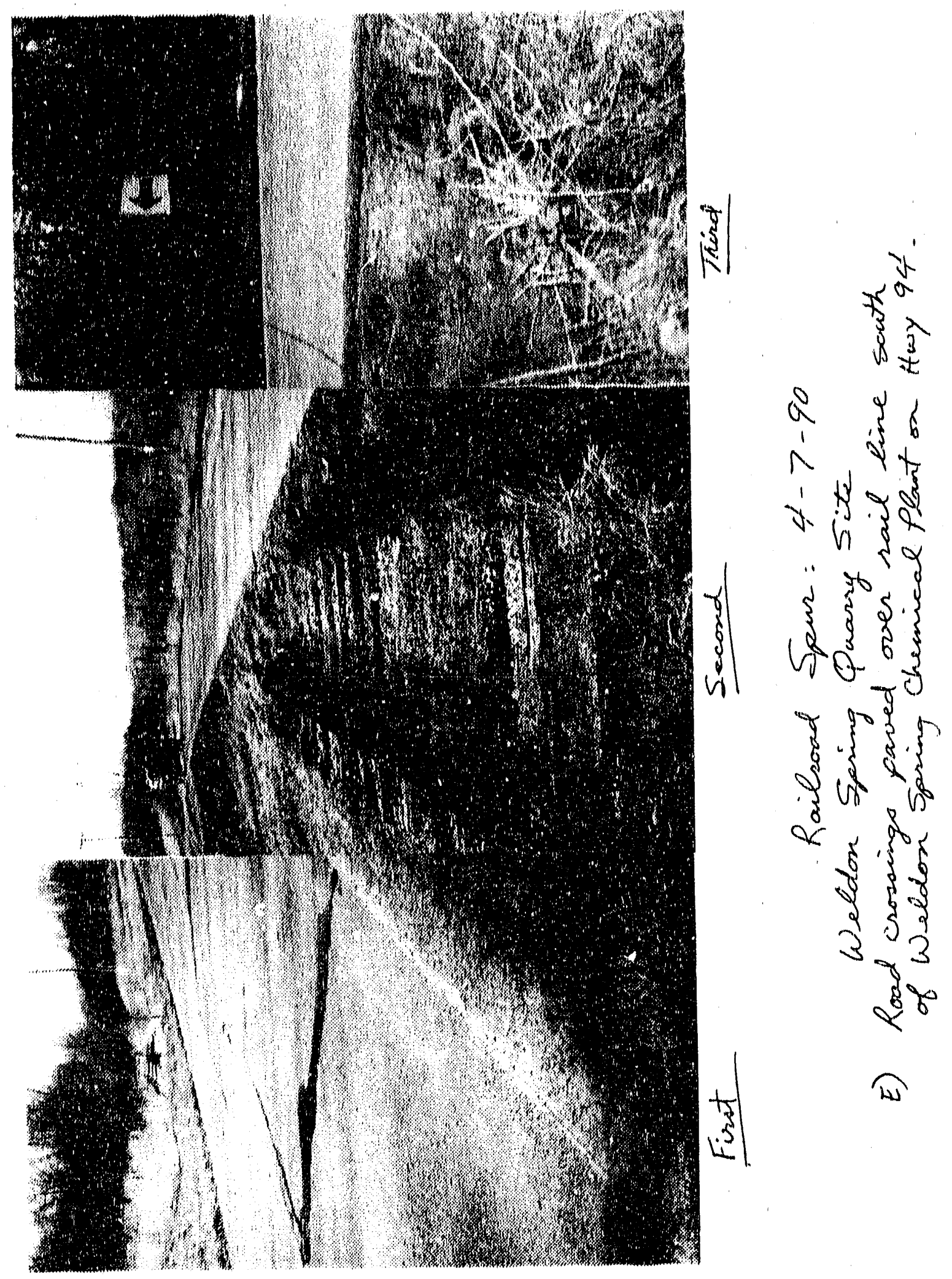




\section{BIBLIOGRAPHY}

Argonne National Laboratory, 1990, Feasibility Study for Management of the Bulk Wastes at the Weldon Spring Quarry, Weldon Spring, Missouri, DOE/OR/21548-104, prepared by Argonne National Laboratory, Environmental Assessment and Information Sciences Division, Argonne, Ill., for U.S. Department of Energy, Oak Ridge Operations Office, Weldon Spring Site Remedial Action Project, Weldon Spring, Mo., Feb.

Argonne National Laboratory, 1990, Proposed Plan for Management of Bulk Wastes at the Weldon Spring Quarry, Weldon Spring, Missouri, DOE/OR/21548-105, prepared by Argonne National Laboratory, Environmental Assessment and Information Sciences Division, Argonne, Ill., for U.S. Department of Energy, Oak Ridge Operations Office, Weldon Spring Site Remedial Action Project, Weldon Spring, Mo., Feb.

Arthur D. Little, Inc., 1987, Testing to Determine the Relationship Between Explosive Contaminated Sludge Components and Reactivity, AMXTH-TE-CR-86096, prepared by F.T. Kristoff, T.W. Ewing, and D.E. Johnson, Arthur D. Little, Inc., Cambridge, Mass., for U.S. Army Toxic and Hazardous Materials Agency, Aberdeen Proving Ground, Md., Jan.

Haroun, L.A., et al., 1990, Baseline Risk Evaluation for Exposure to Bulk Wastes at the Weldon Spring Quarry, Weldon Spring, Missouri, DOE/OR/21548-065, prepared by Argonne National Laboratory, Environmental Assessment and Information Sciences Division, Argonne, Ill., for U.S. Department of Energy, Oak Ridge Operations Office, Weldon Spring Site Remedial Action Project, Weldon Spring, Mo., Jan.

Hercules Incorporated, 1990, Explosive Hazard Review for the Weldon Spring Site Remedial Action Project Quarry Excavation, HERC No. 90-26, prepared by W.R. Workman and T.A. Groce, Hercules Missiles, Ordnance \& Space Group, Allegany Ballistics Laboratory, Rocket Center, W. Va., for MK-Ferguson Company, St. Charles, Mo., July.

MacDonell, M.M., M.L. Maxey, I.E. Joya, and J.M. Peterson, 1990, Engineering Evaluation/Cost Analysis for the Proposed Management of Contaminated Water Impounded at the Weldon Spring Chemical Plant Area, DOE/OR/21548-106, prepared by Argonne National Laboratory, Energy and Environmental Systems Division, Argonne, Ill., for U.S. Department of Energy, Oak Ridge Operations Office, Weldon Spring Site Remedial Action Project, Weldon Spring, Mo., July.

MK-Ferguson Company and Jacobs Engineering Group, 1989, Remedial Investigations for Quarry Bulk Wastes, DOE/OR/21548-066, Rev. 1, prepared for U.S. Department of Energy, Oak Ridge Operations Office, Weldon Spring Site Remedial Action Project, Weldon Spring, Mo., Dec.

National Research Council, 1980, The Effects on Populations of Exposures to Low Levels of Ionizing Radiation, BEIR III, Committee on the Biological Effects of Ionizing Radiation, National Academy Press, Washington, D.C. 
National Research Council, 1990, Health Effects of Exposure to Low Levels of Ionizing Radiation, BEIR V, Committee on the Biological Effects of Ionizing Radiation, National Academy Press, Washington, D.C. 

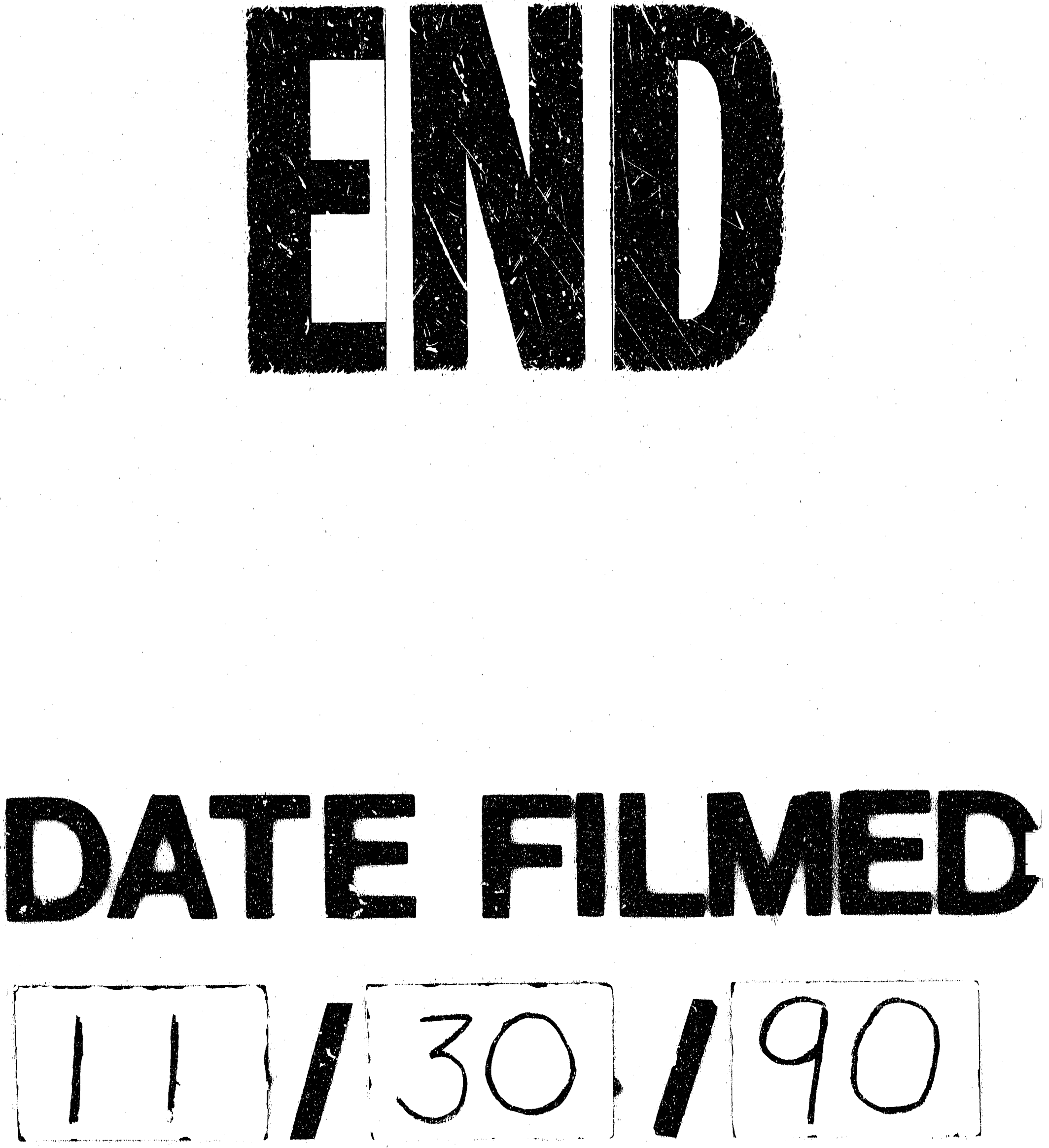
